\title{
The Defamation Injunction Meets the Prior Restraint Doctrine
}

\author{
DOUG RENDLEMAN*
}

\section{TABLE OF CONTENTS}

I. INTRODUCTION

II. BARRIERS TO AN INJUNCTION: PRIOR RESTRAINT AND EQUITY

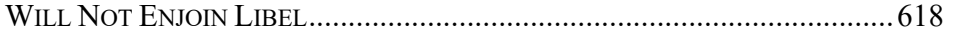

A. Near v. Minnesota and New York Times v. Sullivan .......................621

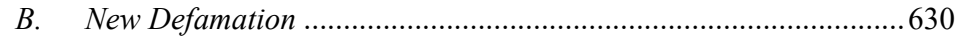

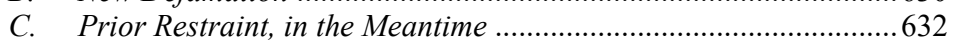

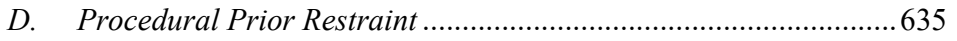

E. Substantive Prior Restraint .............................................................. 636

III. THE CONTEMPORARY DEBATE: BALBOA ISLAND VILLAGE INN,

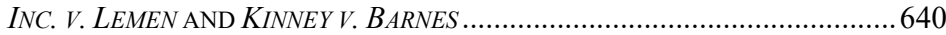

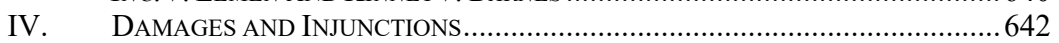

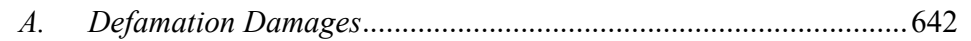

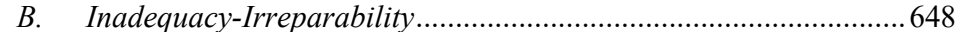

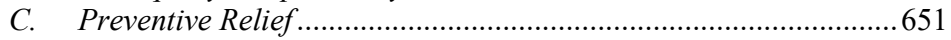

D. Interlocutory Relief ...............................................................652

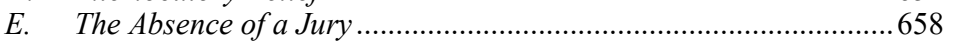

V. AltERnATIVE REMEDIAL APPROACHES ................................................661

A. Declaratory Judgment .................................................................661 661

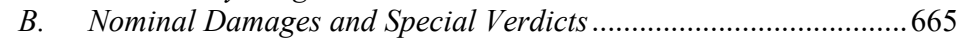

C. Retraction, Reply, Apology, Settlement ........................................666

* C 2019 Doug Rendleman. Huntley Professor, Washington and Lee Law School. Thanks to Martha Vazquez and Trista Bishop-Watt for outstanding research assistance and to the Frances Lewis Law Center for support. An earlier draft benefitted from an airing at the Free Speech Discussion Forum at the University of Luxembourg. Thanks to colleagues John Jeffries and Ron Krotoszynski for careful readings and constructive suggestions. Thanks to Russ Weaver for spirited disagreement that forced me to rethink and sharpen my points. 


\begin{tabular}{|c|c|}
\hline \multicolumn{2}{|r|}{ 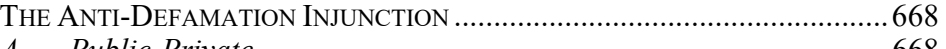 } \\
\hline A. & 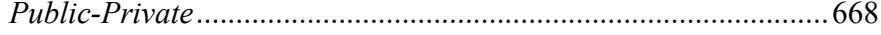 \\
\hline$B$. & Drafting an Injunction ..................... \\
\hline C. & Enforceability .................................. \\
\hline$D$. & Administering the Injunction.......... \\
\hline & 1. Motion to Modify-Dissolve...... \\
\hline & 2. Contempt ................................. \\
\hline & 3. Violation ......................................... \\
\hline & 4. The Collateral Bar Rule ..................................................... \\
\hline & LARS’'ARGUMENTS AGAINST PRIOR RESTRAINTS ................................ \\
\hline
\end{tabular}

\section{INTRODUCTION}

This Article addresses one of the most important issues in free speech today: whether a judge may grant a plaintiff an injunction against a defendant's defamation. ${ }^{1}$ It argues that existing and proposed principles of confinement on granting, drafting, and administering an injunction may overcome an injunction's risks to the defendant's freedom of expression. It concludes that, under limited circumstances, a judge may grant a plaintiff an injunction that forbids a defendant from repeating defamation.

While this Article was in its final stages, I learned about Professor Eugene Volokh's Article, Anti-libel Injunctions and the Criminal Libel Connection. ${ }^{2}$ His Article is an important endorsement of this Article's principal point: An anti-libel injunction is constitutional. A judge should be able to grant a plaintiff an injunction to forbid the defendant's proved libel. The Articles come to the same conclusion from different starting places. This Article discusses Volokh's in its footnotes.

This Article follows the imaginary lawsuit of Baldder v. Lokki to illustrate its points. Lois Lokki hired electrical contractor, Paul Baldder, to install some wiring in her condo. Mutual rancor corroded their relationship. Irritated about both the quality of his work and the size of his bill, she declined to pay the latter. After missing some jewelry from her dresser, she began a campaign against him on GripeLex, a community consumer website. In addition to attacking his workmanship and charges, she accused him of being a thief who stole her necklaces. Later Lokki found the jewelry in her drawer, but still livid, she has not cleaned up her GripeLex posts.

1. David S. Ardia, Freedom of Speech, Defamation, and Injunctions, 55 WM. \& MARY L. REV. 1, 5-6 (2013).

2. Eugene Volokh, Anti-Libel Injunctions and the Criminal Libel Connection, 167 U. PA. L. REV. (forthcoming 2019) (on file with the author). 
Baldder sued Lokki for libel in the Lex state court. His demand for judgment includes money recovery, compensatory damages, and punitive damages, plus an injunction that requires Lokki to remove the libelous statements from GripeLex and forbids her from repeating them in any form or format.

Baldder v. Lokki is loosely based on the events in the Virginia Supreme Court's short decision in Perez v. Dietz Development, LLC. ${ }^{3}$ The circuit judge had granted plaintiff, a remodeling contractor, a preliminary injunction that required defendant, a condo dweller, to delete defamatory criticism from Yelp. ${ }^{4}$ The Virginia Supreme Court, after accepting defendant's petition for review, disapproved the trial judge's take-down preliminary injunction, observing that damages were "an adequate remedy at law" for plaintiff. ${ }^{5}$ In other words, plaintiff might be able to recover money damages for defamation from defendant, but he could not force her to remove her defamatory comments from Yelp. ${ }^{6}$

Baldder v. Lokki assures Lokki's substantive tort liability for defamation: a home-owner defendant's false accusation that a home-repair contractor is a thief is a defamatory factual statement, either orally or in writing. ${ }^{7}$ Lokki communicated the falsehood to others; this speech was not an isolated her-face-to-his-face affront. It was factual, not opinion. She intended to communicate those facts to Baldder's potential customers. If believed, her remarks will lead many readers to direct their home repair projects elsewhere. If so, Baldder will lose business. The public interest in consumer protection is not well served by a disgruntled homeowner's inaccurate evaluations. Her charges are not core political speech.

This Article argues and concludes that the barriers to granting a plaintiff like Baldder an injunction against a defendant's defamation should be lowered or eliminated. This Article unfolds as follows: It introduces two anti-injunction doctrines - the prior restraint rule or doctrine and the Maxim, "Equity will not enjoin defamation." It summarizes Near v. Minnesota ex

3. No. 122157, 2012 WL 6761997 (Va. Dec. 28, 2012).

4. Id. at *1; Justin Jouvenal, In Suit over Online Reviews, Neither Side Wins Damages, WASH. PosT, Feb. 2, 2014, at C5.

5. Perez, 2012 WL 6761997, at*1.

6. See id. In early 2014 , Perez went to a jury trial of plaintiff's claim and defendant's counterclaim both for libel. Jouvenal, supra note 4. After a five-day trial followed by eight hours of deliberations, the jury found defamation on both sides but returned a zero verdict for both. Id.

7. 3 Dan B. Dobbs, Paul T. Hayden \& Ellen M. Bublick, The Law of Torts $\S 534$, at 225 (2d ed. 2011). 
rel. Olson, ${ }^{8}$ wherein the United States Supreme Court added an injunction to executive licensing as a prior restraint and subordinated the injunction to a criminal prosecution or a money judgment. ${ }^{9}$

The New York Times Co. v. Sullivan privileges, ${ }^{10}$ which circumscribe many plaintiffs' defamation actions, are considered, as they must be. This Article examines the development of "new defamation" in two state supreme courts' decisions. In Balboa Island Village Inn, Inc. v. Lemen, the California court countenanced granting the plaintiff an injunction against the defendant's defamation. ${ }^{11}$ In Kinney $v$. Barnes, on the other hand, the Texas court rejected such an injunction. ${ }^{12}$

To inquire whether an injunction menaces free speech more than a damages judgment, this Article analyzes defamation damages and several differences between an injunction and a damages judgment. It turns to scholars' arguments against an injunction as a prior restraint and proposed reforms; it finds them unconvincing. A carefully adjudicated and drafted injunction that specifically forbids defendant's defamation, it concludes, will not imperil free speech values. It commends abolition of the Maxim and suspension or qualification of the prior restraint doctrine.

\section{BARRIERS TO AN INJUNCTION: PRIOR RESTRAINT AND EQUITY WILL NOT ENJOIN LIBEL}

A plaintiff seeking an injunction that forbids a defendant's defamation must surmount two sturdy barriers. ${ }^{13}$ The prior restraint doctrine is Baldder's the first barrier. The doctrine applies everywhere in the United States because the Supreme Court based it on the Constitution. ${ }^{14}$ This Article will examine prior restraint decisions that involve defamation, as seen in Near v. Minnesota ex rel. Olson, ${ }^{15}$ the United States Supreme Court's 1931 granddaddy priorrestraint opinion; $;{ }^{16}$ Balboa Island Village Inn, Inc. v. Lemen, ${ }^{17}$ the California Supreme Court's 2007 decision that sanctioned an anti-defamation injunction; ${ }^{18}$ and the Texas court's 2014 decision in Kinney v. Barnes that rejected an antidefamation injunction. ${ }^{19}$ Near, Balboa, and Kinney all involve plaintiffs

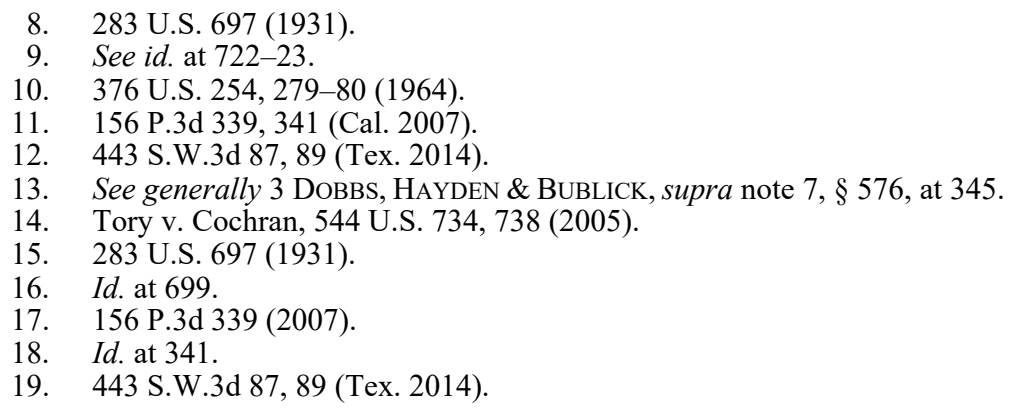


seeking injunctions against their respective defendant's defamation, albeit in different legal settings.

In Near, the public authorities sued Jay Near for defamation under a Minnesota public nuisance statute, seeking an injunction. ${ }^{20}$ In Balboa and Kinney, private litigants sued their defendants for the common law tort of defamation, both seeking an injunction. ${ }^{21}$ Tory $v$. Cochran is the United States Supreme Court's most recent venture into defamation. ${ }^{22}$ That cryptic decision will receive less attention, however, because plaintiff Johnnie Cochran died while the appeal was pending and the Supreme Court did not adjudicate an injunction against defamation. ${ }^{23}$

Baldder's second obstacle is the Maxim that "Equity will not enjoin defamation." 24 The Lex state courts wield the Maxim which they found in their common law and state constitution. ${ }^{25}$ The pre-merger rule that Equity lacked jurisdiction to enjoin libel, which was mostly an adequate remedy at law and jury trial rule, became more of a free speech rule after Near and the merger of law and equity. Before merger, a separate Chancery court would lack equity jurisdiction to enjoin libel; after merger, the merged court had equity jurisdiction and the post-merger Maxim "Equity will not enjoin a libel" was still based on the preference for jury trial. ${ }^{26}$ The Maxim is broader than the prior restraint rule. "Defamation alone is not a sufficient justification for restraining an individual's right to speak freely," observed the Texas court in Hajek v. Bill Mowbray Motors, Inc. ${ }^{27}$ And, as in Lex, state courts often implement the Maxim under their states' constitutions. ${ }^{28}$

20. See Near, 283 U.S. at 701-02.

21. Balboa Island Vill. Inn, 156 P.3d at 341; Kinney, 443 S.W.3d at 89.

22. 544 U.S. 734, 735-37 (2005).

23. Id. at 734 .

24. 3 DoBBS, HAYDEN \& Bublick, supra note 7, § 576, at 345; see also Kinney, 443 S.W.3d at 95 (citing Kramer v. Thompson, 947 F.2d 666, 677 (3d Cir. 1991)). Trade libel is an exception to the Maxim that this article does not consider further. See, e.g., CapStack Nashville 3 L.L.C. v. MACC Venture Partners, No. 2018-0552-SG, 2018 WL 3949274, at *4-5 (Del. Ch. Aug. 16, 2018); Organovo Holdings, Inc. v. Dimitrov, 162 A.3d 102, 124-27 (Del. Ch. 2017).

25. 3 DOBBS, HAYDEN \& BUBlick, supra note 7, § 576, at 345; Ardia, supra note 1, at 50 .

26. See Organovo Holdings, 162 A.3d at 115-17.

27. 647 S.W.2d 253, 255 (Tex. 1983) (citing Ex parte Tucker, 220 S.W. 75, 76 (Tex. 1920))

28. See, e.g., Fernandez v. N. Ga. Reg'1 Med. Ctr., Inc., 400 S.E.2d 6, 7-8 (Ga. 1991); Brannon v. Am. Micro Distrib., Inc., 342 S.E.2d 301, 302-03 (Ga. 1986); Sid Dillon Chevrolet-Oldsmobile-Pontiac, Inc. v. Sullivan, 559 N.W.2d 740, 746 (Neb. 1997); Kinney, 443 S.W.3d at 95; Ardia, supra note 1, at 50. 
Baldder's demand for an injunction forbidding Lokki's defamation is doomed unless the Lex court takes this Article's advice and scuttles the Maxim.

Even though GripeLex republished Lokki's defamatory remarks, Lokki is Baldder's only viable defendant. Section 230 of the federal Communications Decency Act eliminates GripeLex as a defendant. ${ }^{29}$ The statute grants immunity to Internet Service Providers (ISPs) like GripeLex and Yelp. Under the tort-reform provision, a republishing website is immune from a plaintiff's libel suit for damages. ${ }^{30}$ Authority has been divided on whether the provision may also protect an ISP from a plaintiff's demand for an injunction, but the trend favors barring an injunction. ${ }^{31}$ If, moreover, Lokki had posted her defamation anonymously and if Baldder had sued the ISP, her identity would probably also be protected. ${ }^{32}$

29. See 47 U.S.C. $\$ 230(c)(1)(2012)$.

30. See id.; Jones v. Dirty World Entm't Recordings, LLC, 840 F. Supp. 2d 1008, 1010 (E.D. Ky. 2012); Blockowicz v. Williams, 675 F. Supp. 2d 912, 914 (N.D. Ill. 2009), aff'd, 630 F.3d 563 (7th Cir. 2010); Shiamili v. Real Estate Group of N.Y., Inc., 952 N.E.2d 1011, 1016-17 (N.Y. 2011); Reit v. Yelp!, Inc., 907 N.Y.S.2d 411, 413 (Sup. Ct. 2010). But see Barnes v. Yahoo!, Inc., 570 F.3d 1096, 1107 (9th Cir. 2009) (finding that Yahoo, which is immune under the CDA, may be estopped for failing to remove content that it promised to take down). An exception occurs when the website participates in creating the statement. Huon v. Denton, 841 F.3d 733, 741-43 (7th Cir. 2016) (piercing Communications Decency Act $\S 230$ (c) immunity for websites when website provides content).

31. See, e.g., Hassell v. Bird, 420 P.3d 776, 788 (Cal. 2018) (involving a removal order used by the plaintiffs who sought to overrule Yelp's decision to publish the three challenged reviews). Where, as here, an internet intermediary's relevant conduct in a defamation case goes no further than the mere act of publication-including a refusal to depublish upon demand, after a subsequent finding that the published content is libeloussection 230 prohibits this kind of directive. 47 U.S.C. $\S 230(\mathrm{c})$; Noah v. AOL Time Warner, Inc., 261 F. Supp. 2d 532, 539-40 (E.D. Va. 2003) (barring a plaintiff's Title II of the Civil Rights Act claim against AOL because of section 230), aff'd, No. 03-1770, 2004 WL 602711, at*1 (4th Cir. Mar. 24, 2004); Ardia, supra note 1, at 16 (citing 47 U.S.C. $\S 230)$.

The result in Canada would have differed. See generally Google Inc. v. Equustek Sols. Inc., [2017] 1 S.C.R. 824, 826 (Can.) (requiring nonparty Google to delist defendant Datalink's websites). A sequel in the United States followed. See Google LLC v. Equustek Sols. Inc., No. 5:17-cv-04207-EJD, 2017 WL 5000834, at*1-2, *7-8 (N.D. Cal. Nov. 2, 2017) (barring enforcement of the Canadian judgment by default order based on section 230).

32. See generally Enterline v. Pocono Med. Ctr., 751 F. Supp. 2d 782, 789 (M.D. Pa. 2008); Solers, Inc. v. Doe, 977 A.2d 941, 954 (D.C. 2009); Indep. Newspapers, Inc. v. Brodie, 966 A.2d 432, 456 (Md. 2009); Thomas M. Cooley Law Sch. v. Doe 1, 833 N.W.2d 331, 344 (Mich. Ct. App. 2013); In re Doe, 444 S.W.3d 603, 607-08 (Tex. 2014) (finding that a plaintiff must show that the state has personal jurisdiction over the defendant before compelling his or her identity). But see Warren Hosp. v. Does 1-10, 63 A.3d 246, 251 (N.J. Super. Ct. App. Div. 2013); Cohen v. Google, Inc., 887 N.Y.S.2d 424, 429-30 (Sup. Ct. 2009); Yelp, Inc. v. Hadeed Carpet Cleaning, Inc., 752 S.E.2d 554, 567 (Va. Ct. App. 2014) (finding that anonymous online reviews are not entitled to First Amendment protection if the person reviewing was not actually a consumer, making the statements false). 


\section{$A$. Near v. Minnesota and New York Times v. Sullivan}

Jay Near was a pest. ${ }^{33}$ His Saturday Press excoriated the Twin Cities authorities. ${ }^{34}$ He accused them of lax, even corrupt, administration of the prohibition laws. ${ }^{35}$ His heavy-handed anti-Semitic stories tied the local authorities to Jewish gangsters and criminals. ${ }^{36}$ Those authorities sued Jay Near under a Minnesota public nuisance statute. ${ }^{37}$ Although it was a libel case, the plaintiffs' substantive base was a statute that the legislature had amended to add defamation to obscenity as a public nuisance. ${ }^{38}$ The statute allowed a judge to grant a plaintiff an injunction against a defendant's "malicious, scandalous and defamatory newspaper, magazine or other periodical." 39

The trial judge granted plaintiffs an ex parte injunction. ${ }^{40}$ It forbade Jay Near from publishing a newspaper "containing malicious, scandalous and defamatory matter of the kind alleged in plaintiff's complaint herein or otherwise. ${ }^{41}$ Jay Near ceased publishing his paper. ${ }^{42}$ The Minnesota Supreme Court affirmed. ${ }^{43}$

Because of the way the lawsuit had been formulated and argued in the lower courts, the United States Supreme Court reviewed the statute, not the injunction. ${ }^{44}$ In a decision in the early days of federal court review of state free speech decisions, the Court held that the Minnesota statute was a prior restraint that violated the Constitution. ${ }^{45}$

33. See Near v. Minnesota ex rel. Olson, 283 U.S. 697, 703 (1931).

34. See id.

35. See Fred W. Friendly, Minnesota Rag: The Dramatic Story of the LandMark Supreme Court Case that Gave New Meaning to Freedom of the Press 43 (1981) (providing the readable account of Near).

36. See id.

37. Near, 283 U.S. at 703.

38. Id. at 702 (quoting 1925 Minn. Laws 358).

39. Id. (quoting 1925 Minn. Laws 358); FRIENDLY, supra note 35, at 40-54.

40. See Near, 283 U.S. at 704-05.

41. Id.

42. See FRIENDLY, supra note 35 , at 54 .

43. Near, 283 U.S. at 706-07.

44. Id. at 708 .

45. See id. at 722-23. I say "Constitution" instead of "First Amendment" here because the majority opinion referred to the Fourteenth Amendment instead of the First. Professor Kauper discussed the tension between the First and the Fourteenth Amendments. PAUL G. KAUPER, CiVIL Liberties AND THE CONSTITUTION 53-85 (1962). 
The prior restraint doctrine had been around for some time to reprobate executive censorship through advance licensing. ${ }^{46}$ The Near Court's innovation was to add the public nuisance statute and its judicial injunction to executive licensing as a prior restraint. ${ }^{47}$ Justice Butler dissented on this point. ${ }^{48}$ The Court's majority insisted that the prior restraint doctrine affected only a plaintiff's injunction against a defendant's libel and that it left available both a plaintiff's civil libel action for money damages and the authorities' criminal prosecutions for libel. ${ }^{49}$ The Court's majority contrasted the banned injunction as a prior restraint with civil damages and a criminal prosecution, the preferred "subsequent punishments."

We usually think of the criminal law as the government's heavy artillery in contrast to the civil law for damages and an injunction, which are lesser remedies for defendants' misconduct. ${ }^{51}$ However, the Near Court subordinated the ostensibly "milder" injunction remedy to both the authorities' criminal prosecution and the private civil plaintiff's libel tort for money damages. ${ }^{52}$ The Court maintained that an injunction threatens the defendant's free speech values more than either of the subsequent punishments: a criminal prosecution-conviction or a civil judgment for money damages. ${ }^{53}$ This remedial reversal is an anomaly. After exploring the decision to favor the civil damages action over the injunction, this Article argues that to correct the anomaly courts should, under proper circumstances, cease disfavoring the injunction.

In Near, several procedural and substantive defects clamored for the Court's attention. ${ }^{54}$ The trial judge's procedure was ex parte; Jay Near lacked notice in advance and an opportunity to be heard in opposition. ${ }^{55}$ The substantive libel doctrine was broad, imprecise, and vague. In pleading or at a factual hearing, the public nuisance statute put the burden of proof of his good faith on the defendant instead of requiring the plaintiff to prove the defendant's bad faith. ${ }^{56}$ In a plenary hearing on an injunction, Jay Near

46. See Near, 283 U.S. at 723 (Butler, J., dissenting).

47. See id. at $722-23$.

48. Id. at $735-36$.

49. See id. at 713 (majority opinion).

50. Id. at 713-14 (quoting Patterson v. Colorado, 205 U.S. 454, 462 (1907)).

51. Francis A. Allen, The Morality of Means: Three Problems in Criminal Sanctions, 42 U. PitT. L. ReV. 737, 738-39 (1981); Michal Buchhandler-Raphael, Overcriminalizing Speech, 36 CARDOZO L. REV. 1667, 1730-31 (2015).

52. See Near, 283 U.S. at 715.

53. See id. at 716 .

54. See id. at 709-13.

55. See Ardia, supra note 1, at 53-54.

56. Near, 283 U.S. at 709-10. 
would not have been able to summon a jury, although in a criminal prosecution or a tort trial for damages, he would have been entitled to one. ${ }^{57}$

After the Supreme Court's Near decision, the overreaching law of libel changed. First, the existence of the criminal libel statutes that the Near Court endorsed spoke to the possibility that a critic of government officials, like Jay Near, might face jail after a criminal prosecution for his efforts. ${ }^{58}$ This risk was eradicated by the Supreme Court's development of First Amendment protection. ${ }^{59}$ Defamation today is a civil tort, not a crime, even though some states' codes retain obsolete criminal statutes that forbid libel. ${ }^{60}$ The internet defamation this Article examines below is so unlikely to lead to a criminal prosecution - what is more a criminal conviction - that we can consider the statutory criminal law effectively off the table.

Second, as Professor Blasi wrote, "[T]he restraint [injunction] in Near itself ... would surely be invalidated under the modern vagueness doctrine." ${ }^{1}$

Third, in New York Times v. Sullivan and its queue of decisions, the Supreme Court undermined a public official's libel tort for money damages against a critic of his official duties. ${ }^{62}$ To recover damages, the Court required

57. State ex rel. Olson v. Guilford, 219 N.W. 770, 773 (Minn. 1928) (refusing to extend the right to a jury trial to an equitable action), rev'd sub nom. Near v. Minnesota ex rel. Olson, 283 U.S. 697 (1931).

58. See Near, 283 U.S. at 711.

59. See, e.g., Garrison v. Louisiana, 379 U.S. 64, 69-70 (1964) (stating that libel may be "inappropriate for penal control"); State v. Turner, 864 N.W.2d 204, 210-11 (Minn. Ct. App. 2015); Parmelee v. O’Neel, 186 P.3d 1094, 1098-106 (Wash. Ct. App. 2008); Lyrissa Lidsky \& Andrea Pinzon Garcia, How Not to Criminalize Cyberbullying, 77 Mo. L. REV. 693, 720 (2012).

60. See, e.g., VA. CodE ANN. § 18.2-417 (West 2019). Volokh's Article, in contrast, emphasizes an anti-defamation injunction's criminal law connections. The Article argues that the "First Amendment does not preclude properly crafted anti-libel injunctions, in part because they are similar to constitutionally valid properly crafted criminal libel laws." Volokh, supra note 2 (manuscript at 49).

61. Vincent Blasi, Toward a Theory of Prior Restraint: The Central Linkage, 66 MinN. L. Rev. 11, 12 n.8 (1981); see also William T. Mayton, Toward a Theory of First Amendment Process: Injunctions of Speech, Subsequent Punishment, and the Costs of the Prior Restraint Doctrine, 67 CORNELL L. REV. 245, 279-80 (1982) (arguing that the Near injunction was both too broad and too vague). The Minnesota judge's injunction would also be improper today because the Federal Rules of Civil Procedure forbid incorporation by reference in an injunction. FED. R. CIV. P. 65(d)(1)(C).

62. See N.Y. Times Co. v. Sullivan, 376 U.S. 254, 279-80 (1964); LeE Levine \& Stephen Wermiel, The Progeny: Justice William J. Brennan's Fight to Preserve THE LEGACY OF NEW YORK TIMES V. SULLIVAN 109-10 (2014) (providing a later and more technical treatment of Sullivan); ANTHONy Lewis, MAKe No Law: The Sullivan CASE AND THE FIRST AMENDEMNT 130-39 (1991) (providing the readable account for Sullivan). 
a public-figure libel plaintiff to prove the defendant's "actual malice," that the defendant knew or should have known that its allegedly defamatory statement was false. ${ }^{63}$ The Sullivan principle protects a defamation defendant from a public-figure libel plaintiff's tort if that defendant did not know and should not have known that its statement was false. ${ }^{64}$

The reader should prepare for some technicality in the tort law of defamation. Even before the Supreme Court decided Sullivan, Professor Leon Green had written of defamation that "[n]o other formula of the law promises so much and delivers so little." ${ }^{65}$ After Sullivan, Professor Bill Van Alstyne warned that the substantive law of defamation is "bewilderingly complicated," nuanced, and unclear. ${ }^{66}$ Although it has taken a while, the official plaintiff's libel action against a media defendant is desiccated, perhaps essentially over. ${ }^{67}$

Defamation's complex principles remain controversial. If elected, thencandidate President Trump said:

\begin{abstract}
I'm going to open up our libel laws so when they write purposely negative and horrible and false articles, we can sue them and win lots of money. We're going to open up those libel laws. So, when The New York Times writes a hit piece which is a total disgrace or when The Washington Post, which is there for other reasons, writes a hit piece, we can sue them and win money instead of having no chance of winning because they're totally protected. ${ }^{68}$
\end{abstract}

In 2019, Justice Thomas voiced his opposition to the Sullivan principles. ${ }^{69}$ Concurring in the Court's decision to deny the plaintiff's cert petition in McKee v. Cosby, Justice Thomas focused on two ideas: when Sullivan applied, the "actual malice" rule made it almost impossible for a libel plaintiff to prevail, and the "actual malice" rule ignored both the state law of libel and the "original meaning of the Constitution.,"70 Justice Thomas wrote the Sullivan decision and its progeny were "policy-driven decisions masquerading as constitutional law" that should be "reconsidered."" "The States are perfectly

63. Sullivan, 376 U.S. at 279-80.

64. See David A. Anderson, Tortious Speech, 47 WASH. \& LeE L. Rev. 71, 80-81 (1990) [hereinafter Anderson, Tortious] (quoting Hustler Magazine, Inc. v. Falwell, 485 U.S. 45, 56 (1988)).

65. Leon Green, The Right to Communicate, 35 N.Y.U. L. REV. 903, 907 (1960).

66. William W. Van Alstyne, First Amendment Limitations of Recovery from the Press-An Extended Comment on "The Anderson Solution," 25 WM. \& MARY L. REV. 793, 816 (1984).

67. Ardia, supra note $1,11 \&$ nn.31-32.

68. Adam Liptak \& Eileen Sullivan, Trump, Angry Over Woodward Book, Renews Criticism of Libel Laws, N.Y. TIMES (Sept. 5, 2018), https://www.nytimes.com/2017/03/ 30/us/politics/can-trump-change-libel-laws.html [https://perma.cc/59LL-WJRU].

69. See generally McKee v. Cosby, 139 S. Ct. 675 (2019).

70. Id. at 676,678 .

71. Id. at 676,682 . 
capable of striking an acceptable balance between encouraging robust public discourse and providing a meaningful remedy for reputational harm." 72

First, the principals for public-figure libel are well-established and probably safe. "Changing New York Times v. Sullivan would require either the Supreme Court to overrule it or a constitutional amendment. Neither is remotely likely, though Mr. Trump could try to appoint Supreme Court justices who would vote to overturn the precedent." 73 Justice Thomas concurred alone; not one of the other eight justices joined him. ${ }^{74}$ Second, Trump himself is now a libel defendant. ${ }^{75}$ Third, the intentional tort that Trump stated would not be protected under the Sullivan principles, anyway. ${ }^{76}$

The Supreme Court's leading decision that bears on the internet defamation we are examining is Gertz v. Robert Welch, Inc. ${ }^{77}$ Where the defamation plaintiff is a private person, not a public figure, the Court approved the plaintiff's damages cause of action for the defendant's negligent defamation because of the State interest in compensating a plaintiff's injury. ${ }^{78}$ "[S]o long as they do not impose liability without fault, the States may define for themselves the appropriate standard of liability for a publisher or broadcaster of defamatory falsehood injurious to a private individual." ${ }^{, 79}$ The Court qualified a plaintiff's damage remedies available under the preceding standard: "States may not permit recovery of presumed or punitive damages, at least when liability is not based on a showing of knowledge of falsity or reckless disregard for the truth." 80 Private-plaintiff decisions hold that the plaintiffs need not prove the defendant's actual malice when recovery is confined to actual injury, though actual malice must be shown if punitive or presumed damages are sought. ${ }^{81}$ A private plaintiff must prove falsity. ${ }^{82}$ Furthermore, events may

72. Id. at 682 .

73. Liptak \& Sullivan, supra note 68.

74. McKee, 139 S. Ct. at 675 .

75. Zervos v. Trump, 74 N.Y.S.3d 442, 444 (Sup. Ct. 2018); Adam Liptak, 'A Bit of Divine Justice': Trump Vowed to Change Libel Law. But Not Like This., N.Y. TimeS (Apr. 2, 2018), https://www.nytimes.com/2018/04/02/us/politics/trump-libel-lawsuit.html [http://perma.cc/6JGC-SBHN].

76. See Gertz v. Robert Welch, Inc., 418 U.S. 323, 342 (1974).

77. Gertz, 418 U.S. 323.

78. Id. at 323 .

79. Id. at 347

80. Id. at 347,349 .

81. David A. Anderson, Is Libel Law Worth Reforming?, 140 U. PA. L. REV. 487, 501 (1991) [hereinafter Anderson, Reforming].

82. See Phila. Newspapers, Inc. v. Hepps, 475 U.S. 767, 775-76 (1986). 
transmogrify a private person into a limited-purpose public figure, ${ }^{83}$ who must show Sullivan malice. ${ }^{84}$

Sub-rules developed. Plaintiff's proof must be "clear and convincing." 85 The trial judge and all appellate courts wield "independent," perhaps de novo, review of the jury's factual findings. ${ }^{86}$ Defendants' ready access to motions to dismiss and motions for summary judgment will avoid plaintiff's intrusive and expensive discovery. ${ }^{87}$ Section 230 of the federal Communications Decency Act shields a website from liability for another's tort. ${ }^{88}$ A defamation defendant may use general defensive tactics to protect itself. ${ }^{89}$ Defendant may employ a state anti-Strategic Lawsuits Against Public Participation (SLAPP) statute to flush out a plaintiff's weak lawsuit. ${ }^{90}$ And in federal court, "plausibility" pleading makes a plaintiff's implausible complaint vulnerable to the defendant's motion to dismiss for failure to state a claim. ${ }^{91}$ Requiring a public-figure defamation plaintiff to allege a plausible claim helps to protect against expensive and baseless litigation. ${ }^{92}$

Although defendant Lokki found her jewelry, she didn't correct her GripeLex post. The Gertz v. Robert Welch, Inc. Court's qualification does not let an intentional tortfeasor off the hook. ${ }^{93}$ Indeed, a plurality opinion in Dun \& Bradstreet, Inc. v. Greenmoss Builders, Inc. dealing with a private plaintiff's defamation case over the "purely private concern" of an incorrect credit report supported a state's application of any liability standard to protect or vindicate the plaintiff"s reputation: "[W]e hold that the state interest [in compensation] adequately supports awards of presumed and punitive damages — even absent a showing of 'actual malice." "94 In a libel suit for damages,

83. See, e.g., Waldbaum v. Fairchild Publ'ns, Inc., 627 F.2d 1287, 1300 (D.C. Cir. $1980)$.

84. See McKee v. Cosby, 874 F.3d 54, 61-62 (1st Cir. 2017).

85. Robert D. Sack, New York Times Co. v. Sullivan-50-Year Afterwords, 66 AlA. L. REv. 273, 274 (2014) (citing N.Y. Times Co. v. Sullivan, 376 U.S. 287, 285 n.26 (1964)).

86. See id. (citing Sullivan, 376 U.S. at 285 n.26).

87. See David A. Anderson, The Promises of New York Times v. Sullivan, 20 Roger Williams U. L. Rev. 1, 5-6 (2015) [hereinafter Anderson, Promises].

88. Sack, supra note 85, at 289 (citing 47 U.S.C. $\$ 230$ (2013)).

89. E.g., Anderson, Promises, supra note 87, at 6.

90. Id.

91. Sack, supra note 85, at 289 n.96 (quoting Ashcroft v. Iqbal, 556 U.S. 662, 678 79 (2009)).

92. Palin v. N.Y. Times Co., 264 F. Supp. 3d 527, 533 (S.D.N.Y. 2017) (first quoting Biro v. Condé Naste, 963 F. Supp. 2d 255, 279 (S.D.N.Y. 2013), and then quoting Michel v. NYP Holdings, Inc., 816 F.3d 686, 702 (11th Cir. 2016)), vacated and remanded No. 17-3801-cv, 2019 WL 3558545 (2d Cir. Aug. 6, 2019).

93. See 418 U.S. 323, 340 (1974).

94. Dun \& Bradstreet, Inc. v. Greenmoss Builders, Inc., 472 U.S. 749, 759, 761 (1985); see Frederick Schauer, Public Figures, 25 WM. \& MARY L. REV. 905, 919 (1983). 
Baldder might achieve a judgment for compensatory damages and possible punitive damages.

The Sullivan decisions protect some incorrectness, at least from plaintiffs' damages actions. ${ }^{95}$ A high-water mark in free speech, Sullivan tolerates some false speech to contribute to an overall flow of truthful speech. ${ }^{96}$ Falsity may exceed the threshold. Left unanswered is the issue this Article examines: whether under some circumstances, an injunction against a defendant's expression would escape doom as a forbidden prior restraint.

The law and falsity have a tumultuous relationship. Lying is not punished, as such. ${ }^{97}$ Perjury is a narrow criminal offence, not in realistic play for a consumer who calls a contractor a thief. No First Amendment protection exists for fraud. ${ }^{98}$ And fraud-misrepresentation is a hedged and complex tort. ${ }^{99}$ In 2012 in its Stolen Valor Act decision, the Supreme Court voided a criminal statute that forbade falsely claiming a military medal. ${ }^{100}$ A citizen's lie must be relevant and material to strip him of citizenship, the Court held in 2017. ${ }^{101}$ A state criminal statute against false campaign statements did not survive strict scrutiny under the state constitution. ${ }^{102}$ Another decision held that government regulations of charities that barred fees above a certain percentage were not prior restraints. ${ }^{103}$

Justice Breyer asked:

Can we simply say that the First Amendment protects false statements? Sometimes it does. Consider statements of religion, philosophy, history. "The earth is flat" would be protected irrespective of whether one believes it true or false. But sometimes it does not. Consider false commercial speech, fraud, perjury, false claims of terrorist attack, impersonation of police officials, trademark infringement, and other instances where protection would be unwarranted. ${ }^{104}$

95. N.Y. Times Co. v. Sullivan, 376 U.S. 254, 279 n.19 (1964) (quoting JOHN STUART MiLl, On LiBERTY 33 (2d ed. 1859)).

96. Brian C. Murchison, Speech and the Truth-Seeking Value, 39 ColuM. J.L. \& ARTS 55, 59, 103-04 (2015).

97. See United States v. Alvarez, 567 U.S. 709, 718 (2012).

98. United States v. Stevens, 559 U.S. 460, 468 (2010).

99. See 3 DoBBS, HAYDEN \& BUBLICK, supra note 7, § 656, at 616.

100. Alvarez, 567 U.S. at 709.

101. Maslenjak v. United States, 137 S. Ct. 1918, 1922 (2017).

102. Commonwealth v. Lucas, 34 N.E.3d 1242, 1257 (Mass. 2015).

103. Illinois ex rel. Madigan v. Telemarketing Assocs., Inc., 538 U.S. 600, 612 (2003).

104. Stephen Breyer, The Court AND the World: American LAW AND THE NEW Global Realities 258 (2015) (citing Alvarez, 567 U.S. at 713-14). 
Defamation is particularly conflicted. In Sullivan, Justice Brennan summarized the argument for free speech with his statement that discussion of public affairs ought to be "uninhibited, robust, and wide-open." 105

On the other hand, a false statement can be harmful. Justice Stewart pointed out that " $[t]$ he right of a man to the protection of his own reputation from unjustified invasion and wrongful hurt reflects no more than our basic concept of the essential dignity and worth of every human being-a concept at the root of any decent system of ordered liberty."106 Professor Anderson added:

No matter how much it values speech, however, a civilized society cannot refuse to protect reputation. Some form of libel law is as essential to the health of the commonweal and the press as it is to the victims of defamation. Without libel law, credibility of the press would be at the mercy of the least scrupulous among it, and public discourse would have no necessary anchor in truth. ${ }^{107}$

\section{Professor Robert O’Neil wrote that:}

Despite the strong rhetoric about how public discourse needed to be "uninhibited, robust[,] and wide open," when the dust settled, there were still situations in which free speech and press could be subordinated to "individual interests in economic ventures, standing in the community, or general good feelings." ... [L]ibel remains, as it has always been, a unique area of First Amendment law ....108

The Sullivan Court had quoted John Stuart Mill in a footnote: "Even a false statement may be deemed to make a valuable contribution to public debate, since it brings about 'the clearer perception and livelier impression of truth, produced by its collision with error."'109 Negligent errors, the Court added, are "inevitable" in debate. ${ }^{110}$ The Supreme Court's last word on falsity is that "some false statements are inevitable."

The Supreme Court is also on the side of truth. "False statements of fact are particularly valueless," is one of the Supreme Court's observations. ${ }^{112}$ "[F]alse statements" the Court said, "may be unprotected for their own sake.", 13 In Gertz v. Robert Welch, Inc., the Court said that an "erroneous statement of fact is not worthy of constitutional protection." 114 Indeed, the Court's decision in Gertz may be on both sides: on the one hand, "[T] here is no such thing as a false idea" and, on the other hand, "[T]here is no constitutional

105. N.Y. Times Co. v. Sullivan, 376 U.S. 254, 270 (1964).

106. Rosenblatt v. Baer, 383 U.S. 75, 92 (1966) (Stewart, J., concurring).

107. Anderson, Reforming, supra note 81, at 490.

108. Robert M. O'Neil, The First Amendment AND Civil Liability 31, 35 (2001).

109. Sullivan, 376 U.S. at 279 n.19 (1964) (quoting MiLL, supra note 95, at 33).

110. Id. at 271.

111. United States v. Alvarez, 567 U.S. 709, 718 (2012).

112. Hustler Magazine, Inc. v. Falwell, 485 U.S. 46, 52 (1988).

113. BE \& K Constr. Co. v. NLRB, 536 U.S. 516, 531 (2002).

114. 418 U.S. 323, 340 (1974). 
value in false statements of fact. ... which 'are no essential part of any exposition of ideas.", 115

In Hustler Magazine, Inc. v. Falwell, the Court recognized that "[f]alse statements of fact are particularly valueless [because] they interfere with the truth-seeking function of the marketplace of ideas, and [can] cause damage to an individual's reputation that cannot easily be repaired by counterspeech."116 The Court found that false statements are "nevertheless inevitable in free debate."117 As a result, the Court concluded that "a rule that would impose strict liability on a publisher for false factual assertions would have an undoubted 'chilling' effect on speech relating to public figures that does have constitutional value." "118 "Freedoms of expression require 'breathing space.", 119

To advance truth in the long run, the Sullivan principles shield some false statements, some "honest" errors. ${ }^{120}$ "[O]therwise, reporters and editors might well hold back in self-censorship from presenting evidence of misconduct out of fear some minor errors might result in ruinous monetary judgments in favor of an otherwise justly criticized plaintiff." ${ }^{21}$

Nevertheless, excusing present dishonesty in aid of future speech means allowing a defamatory falsehood to escape and injure a plaintiff's reputation without a remedy. ${ }^{122}$ Allowing a present falsehood to advance future truthseeking "must always be carefully weighed against the ultimate cost to the truth-seeking enterprise."123

Trump's inveterate mendacity has altered our attitude about truth versus falsity. As of late April 2019, the Washington Post Fact Checker has identified more than 10,000 of Trump's misleading or false claims. ${ }^{124}$ Justice Stewart

115. Id. at 339-40; see also Milkovich v. Lorain Journal Co., 497 U.S. 1, 18 (1990) (quoting Gertz, 418 U.S. at 339-49).

116. Hustler Magazine, 485 U.S. at 52.

117. Id. (quoting Gertz, 418 U.S. at 340).

118. Id.

119. Id. (quoting Phila. Newspapers, Inc. v. Hepps, 475 U.S. 767, 772 (1986)).

120. Richard Kluger, Indelible InK: The Trials of John Peter Zenger and the BIRTH OF AMERICA's FREE PRESS 301 (2016).

121. Id.

122. See Anderson, Reforming, supra note 81, at 534.

123. Id. at 535 .

124. Glenn Kessler, Salvador Rizzo \& Meg Kelly, President Trump Has Made More than 10,000 False or Misleading Claims, WASH. Post (Apr. 29, 2019), https://www. washingtonpost.com/politics/2019/04/29/president-trump-has-made-more-than-false-ormisleading-claims/?utm_term=.204dcd52ffaf [https://perma.cc/HV5T-RZXG]. 
explained that we should be concerned because "the poisonous atmosphere of the easy lie can infect and degrade a whole society." 25

Next, this article addresses how defamation litigation has changed.

\section{B. New Defamation}

The computer and the internet have altered defamation. ${ }^{126}$ Earlier defamation defendants were newspapers and other corporate media. ${ }^{127}$ These businesses and their employees had long-term professional and ethical commitments to accuracy as well as experienced staffs to ferret out the truth and fact-checkers to confirm it. ${ }^{128}$ In addition, the defendants as huge corporations that carried insurance could count on skilled lawyers to defend a defamation lawsuit and perhaps insurance coverage to pay a damages judgment. ${ }^{129}$ The Sullivan decisions desiccated the public-figure plaintiff's libel action against a media defendant. ${ }^{130}$

In the internet age of social media that this article examines, newspapers are not the defamation defendants. Print journalism has declined. Fewer newspapers and fewer professional journalists produce less printed news. ${ }^{131}$ "American journalism and freedom of expression have been radically recast over the past quarter-century by the tech revolution, greatly to the detriment of traditional hard-copy print media." ${ }^{132}$ Lay bloggers and other internet age denizen are the defendants. ${ }^{133}$ People who previously lacked access to widespread communication can now scream vitriol from their virtual rooftops. ${ }^{134}$

125. Rosenblatt v. Baer, 383 U.S. 75, 94 (1966) (Stewart, J., concurring).

126. See Ardia, supra note 1, at 4-5; Volokh, supra note 2 (manuscript at 3).

127. See Ardia, supra note 1, at 4-5.

128. See id.; Merrill Fabry, Here's How the First Fact-Checkers Were Able to Do Their Jobs Before the Internet, TIME (Aug. 24, 2017), http://time.com/4858683/fact-checkinghistory/ [https://perma.cc/ZKB5-XJ2L].

129. Anderson, Reforming, supra note 81, at 547-48.

130. See id. at 509-10; Anderson, Promises, supra note 87, at 2-3; Sack, supra note 85, at 288. As Professor Murchison has shown, lapses and mistakes continue to occur. See Murchison, supra note 96, at 60-61.

131. See KLUGER, supra note 120, at xvi.

132. Id.

133. See Ardia, supra note 1, at 5; Katherine Mangan, Blasted as Predators, Professors Are Fighting Back with Lawsuits, CHRON. HigHER EDUC. (July 12, 2018), https://www. chronicle.com/article/Blasted-as-Predators/243918/?key=Bj9VwqXvQvYd6fLOxLcWg3 MYGE7aGBtTtbIQbnsxuUDQqzg44d6L-GnhdT2ltQNzN1Vfc (last visited May 22, 2019, 7:10 PM).

134. See Lidsky \& Garcia, supra note 59, at 693-94. Other internet problem areas outside this study are hate crimes and revenge porn. 
Observers think that social media, like alcohol, is disinhibiting because it undermines judgment and exacerbates impulsive and emotional responses. ${ }^{135}$ In the course of granting a plaintiff an interlocutory injunction against ISPs, the Dublin, Ireland, High Court judge wrote that:

[T]he matter went "viral" as they say. All manner of nasty and seemingly idle minds got to work on the plaintiff, and as seems to happen with apparent impunity nowadays on social media sites, said whatever things first came into their vacant, idle and meddlesome heads, by posting statements and comments about the plaintiff, so vile and abusive that I ought not to repeat them here. ${ }^{136}$

Reenter Pam Lokki, Baldder's short-fused condo-dweller defendant. In addition to her hot temper and bad judgment, she lacks a trained journalist's professional education-including the benefit of Washington and Lee's course, JOUR 344 Ethics of Journalism. She also lacks ready access to a specialized lawyer. Her standard homeowners liability insurance policy requires the carrier to defend when an insured is sued and to indemnify, that is to pay a settlement or judgment. But we expect Lokki's insurance carrier to decline coverage under its policy exemption for an intentional tort.

As we said above, a defendant who criticizes a private-person plaintiff does not enjoy the Sullivan privileges that would shelter a defendant for inadvertent error. ${ }^{137}$ Although Lokki owns part of her condo, her assets will not satisfy a large money judgment. In Perez v. Dietz Development, $L L C,{ }^{138}$ our taking-off point, Jane Perez was able to sustain her appeal to the Virginia Supreme Court because the ACLU of Virginia and Public Citizen hoisted their cudgels on her behalf as a consumer critic. ${ }^{139}$ Some consider if a plaintiff's

135. See Anirudh Regidi, Social Media Addiction Is Real, Powerful and Worse than Alcohol, but You Can Fight It with the Right Tools, FirstPOST (Apr. 21, 2017, 9:51 AM), https://www.firstpost.com/tech/news-analysis/social-media-addiction-is-real-powerful-andworse-than-alcohol-but-you-can-fight-it-with-the-right-tools-3701495.html [https://perma.cc/ V3WT-3JZS] (discussing social media addiction).

136. Decision on Interlocutory Injunction Application at 3, McKeogh v. Doe [2012] IEHC 95 (H. Ct.) (Ir.), https://inforrm.files.wordpress.com/2013/05/141943409-mckeoghv-doe-and-others.pdf [https://perma.cc/A3YE-C8NP]. See generally Steven Seidenberg, Lies and Libel: Fake News Is Just False, but the Cure May Not Be So Simple, 103 A.B.A J. 48 (2017) (discussing the effects of social media).

137. See Gertz v. Robert Welch, Inc., 418 U.S. 323, 343-48 (1974); Ardia, supra note 1, at $13-14,13$ n. 41 .

138. No. 122157, 2012 WL 6761997 (Va. Dec. 28, 2012).

139. See Virginia Supreme Court Allows Online Critic's Speech, VA. LIBERTIES (ACLU of Va., Richmond, Va.), Spring 2013, at 1. 
judgment for money damages may be uncollectible from a tortfeasor defendant; this consideration supports the plaintiff's need for an injunction. ${ }^{140}$

\section{Prior Restraint, in the Meantime}

Between Near and Balboa, the prior restraint doctrine evolved and developed in many contexts. To begin, the Supreme Court has neither defined a prior restraint nor developed its exceptions. The prior restraint doctrine, Professor Wells concluded, is ad hoc, elastic, and unstable. ${ }^{141}$

Miscellaneous restrictions on expression that the Court has held to be prior restraints readily illustrate the point above that the prior restraint doctrines are illogical and incoherent. ${ }^{142}$ "The prior restraint doctrine," Professor Fiss wrote, "should not be seen as a full or coherent expression of free speech values, but rather as a strategic device capable of effectuating a compromise, the chief value of which is negative - to block a decision against speech."143

In our adversary system, a lawyer is interested in her client's success, not in convincing the court to develop and articulate coherent doctrine. ${ }^{144}$ A defendant's lawyer has an incentive to label any restriction on a client's expression a prior restraint because successfully pinning that disfavored label on a restriction on a client's expression is a major step toward upsetting it.

Precisely because of the cultural salience and social attractiveness of the very idea of the First Amendment, good advocates, whether in court or in public debate, will try to find a First Amendment hook on which to hang all varieties of claims having little connection with what we might think of as the core goals of the ideas of freedom of speech and freedom of the press. ${ }^{145}$

140. See Cornwell v. Sachs, 99 F. Supp. 2d 695, 707 (E.D. Va. 2000) (“[T]he inability to collect on a damage award may constitute irreparable injury.").

141. See Christina E. Wells, Bringing Structure to the Law of Injunctions Against Expression, 51 CASE W. RES. L. REV. 1, 34, 67 (2000).

142. See generally Riley v. Nat'l Fed'n of the Blind of N.C., Inc., 487 U.S. 781 (1988) (finding that regulations of charities that barred fees above a certain percentage were prior restraints); Smith v. Daily Mail Publ'g Co., 443 U.S. 97 (1979) (discussing a criminal statute that forbade publication of a juvenile offender's name); Se. Promotions, Ltd. v. Conrad, 420 U.S. 546 (1975) (evaluating a refusal to rent a municipal theatre to a production of Hair); Grosjean v. Am. Press Co., 297 U.S. 233 (1936) (deliberating over a gross receipts tax on newspapers). A dissent may stray even farther, see for example, the contractual "species of prior restraint" in Justice Stevens's dissent in Snepp v. United States, 444 U.S. 507, 526 (1980) (Stevens, J., dissenting).

143. Owen M. Fiss, Liberalism Divided: FreEdom of SPEECH AND the MANy Uses OF StATe Power 136 (1996).

144. S.F.C. Milsom, Historical Foundations of THE COMMON LAW 77 (2d ed. 1981).

145. Frederick Schauer, Fish's Five Theories, 9 Fla. InT'L U. L. REV. 21, 29 (2013). 
In litigation, a judge can name a restriction on the defendant's speech a prior restraint to strike it down without stating additional reasons. ${ }^{146}$ The prior restraint target is a desirable goal that is fuzzy at the edges. The Court has neglected Justice Cardozo's warning to guard against " $[t]$ he tendency of a principle to expand itself to the limit of its logic," and beyond. ${ }^{147}$ Even analogy to prior restraint is beneficial to an opponent of a restriction on expression. Witness the Court's analogy in Citizens United v. Federal Election Commission, which struck down statutory limits on corporate campaign contributions because they conflicted with the donor's free speech rights:

This regulatory scheme may not be a prior restraint on speech in the strict sense of
that term, for prospective speakers are not compelled by law to seek an advisory
opinion from the FEC before the speech takes place. As a practical matter, however,
given the complexity of the regulations and the deference courts show to
administrative determinations, a speaker who wants to avoid threats of criminal
liability and the heavy costs of defending against FEC enforcement must ask
a governmental agency for prior permission to speak. These onerous restrictions thus
function as the equivalent of prior restraint by giving the FEC power analogous to
licensing laws implemented in 16th- and 17th-century England, laws and governmental
practices of the sort that the First Amendment was drawn to prohibit. Because the
FEC's "business is to censor, there inheres the danger that it may well be less
responsive than a court-part of an independent branch of government- to the
constitutionally protected interests in free-expression."148

Not only have courts called restrictions prior restraints when prior restraint analysis does not fit, but also, some things that prior restraint analysis fits have evaded prior restraint's bite. ${ }^{149}$ A Rule 26(c) protective order forbids someone from disseminating discovery material that is speech; ${ }^{150}$ it threatens punishment, including contempt. ${ }^{151}$ It fits the definition of prior restraint. Yet courts have not favored protective orders with prior restraint analysis. ${ }^{152}$

146. See, e.g., Doug Rendleman, COMPlex Litigation: InJunCtions, Structural REMEDIES, AND CONTEMPT 1121 (2010); see also Frederick Schauer, The Boundaries of the First Amendment: A Preliminary Exploration of Constitutional Salience, 117 HARV. L. REV. 1765, 1787-1800 (2004) (positing that First Amendment "magnetism" attracts lawyers' opportunistic arguments, in short, the adversary system presses on boundaries).

147. Benjamin N. Cardozo, The Nature of the Judicial Process 51 (1921).

148. Citizens United v. Fed. Election Comm'n, 558 U.S. 310, 335 (2010) (quoting Freedman v. Maryland, 380 U.S. 51, 57-58 (1965))

149. See, e.g., Neb. Press Ass'n v. Stuart, 427 U.S. 539, 570 (1976).

150. See FeD. R. CiV. P. 26(c).

151. See, e.g., Mullally v. City of Los Angeles, 49 F. App'x 190 (9th Cir. 2002) (being unpublished, this case lacks precedential value). Disclosure: I helped draft Mullally's brief.

152. See, e.g., Seattle Times Co. v. Rhinehart, 467 U.S. 20, 33-34 (1984) (noting that a protective order is not a prior restraint). 
Far from naming a protective order a prior restraint, one influential scholar declined to apply any brand of First Amendment analysis to it. ${ }^{153}$ More recently, another scholar has advised courts to apply intermediate-scrutiny First Amendment doctrines to a protective order. ${ }^{154}$ But notably he did not advocate prior restraint's sudden and almost certain death sentence for this useful discovery technique. ${ }^{155}$

Prior restraint has its friends and defenders. ${ }^{156}$ Other scholars, however, suggest reform of this "needless bugaboo." "157 Professor Scordato would limit prior restraint to "physical interception" of speech, eliminating both injunctions and executive licensing from prior restraint. ${ }^{158}$ Professor Redish maintained that prior restraint is procedural only: "A speaker must be afforded an opportunity in a full and fair judicial hearing to contest any restraint before it is imposed. To prove the speech constitutionally unprotected, the government must show a truly compelling interest that outweighs the first amendment right." $" 159$ Fiss and Professor Barnett would distinguish the injunction from executive licensing and liberate the injunction from prior restraint analysis. ${ }^{160}$ Ms. Sarah Shyr, my former student, would allow an injunction under a statute, for example for employment discrimination, but ban that remedy in judgemade common law areas like this Article's topic, defamation. ${ }^{161}$ Professor Jeffries and Professor Mayton argued for abandoning prior restraint as a doctrine. ${ }^{162}$ While I am sympathetic to the abolitionist's outright ban, this

153. See Richard L. Marcus, The Discovery Confidentiality Controversy, 1991 U. ILL. L. REV. 457, 459, 461-62, 473-74 (1991).

154. See Dustin B. Benham, Dirty Secrets: The First Amendment in Protective-Order Litigation, 35 CARDOZO L. REV. 1781, 1783, 1811-13 (2014).

155. See id. at 1811-12.

156. See, e.g., THOMAS I. EMERSOn, THE SYSTEM OF FrEEDOM OF EXPRESSION $503-$ 12 (1970) (discussing some of the criticisms and shortcomings of prior restraint, but defending that the doctrine should not be abandoned all together); Blasi, supra note 61, at 92-93; Howard O. Hunter, Toward a Better Understanding of the Prior Restraint Doctrine: A Reply to Professor Mayton, 67 CoRNELL L. REV. 283, 292-96 (1982); Volokh, supra note 2 (manuscript at $16-17$ ).

157. William O. Bertelsman, Injunctions Against Speech and Writing: A Re-Evaluation, 59 KY. L.J. 319, 332 (1971).

158. Marin Scordato, Distinction Without a Difference: A Reappraisal of the Doctrine of Prior Restraint, 68 N.C. L. REV. 1, 30-31, 31 nn.102-03 (1989).

159. Martin H. Redish, The Proper Role of the Prior Restraint Doctrine in First Amendment Theory, 70 VA. L. REV. 53, 89 (1984).

160. See Owen M. Fiss, The Civil Rights Injunction 69 (1978); Stephen R. Barnett, The Puzzle of Prior Restraint, 29 STAN. L. REV. 539, 544, 548, 551 (1977).

161. Sarah Shyr, Note, Speech Regulation: Why an Injunction Should Be Permissible Under Workplace Discrimination but Is Problematic Under Defamation, 16 WASH. \& LEE J. Civ. RTS. \& Soc. Just. 195, 218, 221-24 (2009).

162. John Calvin Jeffries, Jr., Rethinking Prior Restraint, 92 YALE L.J. 409, 437 (1983); Mayton, supra note 61, at 280-81; see also Volokh, supra note 2 (manuscript at 16). 
Article's prescription is narrower - that under the proper circumstances, an injunction may be an appropriate remedy for a defendant's defamation.

This Article's working definition of a prior restraint is: A prior restraint occurs when the government forbids someone's protected speech before the person has disseminated that speech. ${ }^{163}$ That definition includes both the litigated orders this Article examines and their disreputable ancestor, executive censorship through licensing. It does not include the variations on prior restraint cited in the footnote above. This Article uses the term prior restraint in two separate ways: procedural prior restraint and substantive prior restraint.

\section{Procedural Prior Restraint}

"The settled rule is that a system of prior restraint 'avoids constitutional infirmity only if it takes place under procedural safeguards designed to obviate the dangers of a censorship system." 164 A procedural prior restraint occurs when the process that the authorities' followed to distinguish protected from unprotected expression falls below the First Amendment's procedural threshold. ${ }^{165}$ A court may condemn an order as an improper prior restraint because it forbids a person's speech without the authorities having followed a careful enough decision process to determine accurately whether the speech is protected expression. ${ }^{166}$

The Supreme Court's leading procedural prior restraint decision is Freedman v. Maryland. ${ }^{167}$ The Court dealt with Maryland's since-repealed executive or administrative motion-picture licensing. ${ }^{168}$ The Court required protective procedure for administrative censorship to evaluate material in the contested borderland between the protected sexually explicit and the proscribed obscene subject matter. ${ }^{169}$ An official administrative or executive censor, the Court held, must either grant the applicant permission or proceed

163. See Alexander v. United States, 509 U.S. 544, 544 (1993); Mayton, supra note 61 , at 281 (defining a prior restraint as "a restraint of speech imposed without the checks and examinations of judicial review").

164. Se. Promotions, Ltd. v. Conrad, 420 U.S. 546, 559 (1975) (quoting Freedman v. Maryland, 380 U.S. 51, 58 (1965)).

165. See Freedman, 380 U.S. at 57-58.

166. See, e.g., id. at 60 (holding that state licensing scheme of prior censorship was unconstitutional for lack of adequate procedural safeguards).

167. Freedman, 380 U.S. 51

168. See id. at 52-53.

169. Id. at 58 . 
to court promptly. ${ }^{170}$ The censor has the burden of proof in court. ${ }^{171}$ Permission to disseminate the publication cannot be denied until after a judge determines its obscenity. ${ }^{172}$ The Court, in effect, took the executive censor's ultimate licensing decision and gave it to the judge. ${ }^{173}$

The Freedman Court left ex parte interim orders in a muddled and cryptic state. The Court decided Freedman before it decided Carroll v. Princess Anne, ${ }^{174}$ which this Article examines below. In Carroll, the Court held that an ex parte temporary restraining order forbidding a political rally violated the First Amendment. ${ }^{175}$

\section{E. Substantive Prior Restraint}

This Article turns to what it names the substantive prior restraint. If the judge grants the plaintiff an injunction that regulates the defendant's expression or expression-related activity, the next step is characterization of the injunction as either a prior restraint or not. ${ }^{176}$ As Wells shows with a careful examination of the abortion-clinic injunction in Madsen $v$. Women's Health Center, Inc. ${ }^{177}$ the prior restraint/no prior restraint decision may be arbitrary and unprincipled. ${ }^{178}$ Chief Justice Rehnquist's characterization in Madsen rejects prior restraint analysis in a footnote and contests Justice Scalia's vigorous dissent. ${ }^{179}$ A Washington and Lee School of Law classroom, a proper place to take the temperature of conservative America, regularly rebuffs the Chief Justice and accepts Justice Scalia's outspoken dissent that favors the prior restraint analysis for an abortion-clinic injunction that his Chief rejected.

An injunction is a routine remedy when a defendant's expression has infringed a plaintiff's copyright. The Supreme Court also recognizes exceptions to the prior restraint doctrine. ${ }^{180}$ These are comprised of speech that is not protected expression: obscenity, fighting words, fraud, national security, and, our subject, defamation. ${ }^{181}$

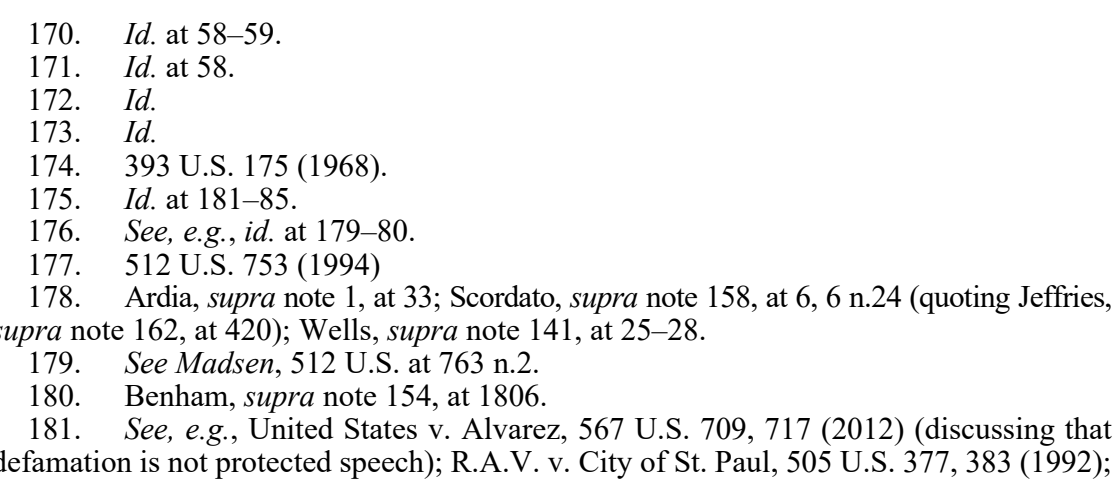


Two generations ago, before New York Times v. Sullivan, the Court said in Chaplinsky v. New Hampshire that libel is excluded from the First Amendment's shelter because it is speech that has "no essential part of any exposition of ideas, and [is] of such slight social value as a step to truth that any benefit that may be derived from [it] is clearly outweighed by the social interest in order and morality." 182

If the defendant's speech is defamatory, the plaintiff may ask the judge to abjure prior restraint analysis and grant an injunction. ${ }^{183}$ However, the Court's excision of defamation from protected expression occurs in the penumbra of the Sullivan privileges that protect a defendant's alleged defamation in the absence of knowledge of falsity or reckless disregard. ${ }^{184}$

If the exceptions do not exclude it, the plaintiff may move for an injunction. The defendant may call the plaintiff's proposed injunction a prior restraint. Then, if the court accepts the defendant's prior restraint characterization, its next step is to apply the rule from the Supreme Court's per curiam opinion in the Pentagon Papers case. ${ }^{185}$ "'Any system of prior restraints of expression comes to this Court bearing a heavy presumption against its constitutional validity.' The Government 'thus carries a heavy burden of showing justification for the imposition of such a restraint."'186 Then, typically, the court finds that the restriction or injunction fails to carry the "heavy burden of showing justification." 187

Between Near and Balboa, the prior restraint doctrine broke down into several subject-matter branches with differing emphasis and results. One branch is free press/fair trial, where the courts attempt to dispel the mist that

Brandenburg v. Ohio, 395 U.S. 444, 447-48 (1969); Buchhandler-Raphael, supra note 51, at 1671 .

182. Chaplinsky v. New Hampshire, 315 U.S. 568, 572 (1942) (citing ZECHARIAH Chafee, Jr., Free Speech in the United States 503 (Harvard Univ. Press 1967) (1941)). The Court reaffirmed this point ten years later in Beauharnais v. Illinois. 343 U.S. 250, 266 (1952) (writing that libel is not "within the area of constitutionally protected speech").

183. See, e.g., Balboa Island Vill. Inn, Inc. v. Lemen, 156 P.3d 339, 343 (Cal. 2007) ("[A]n injunction issued following a trial that determined that the defendant defamed the plaintiff that does no more than prohibit the defendant from repeating the defamation, is not a prior restraint and does not offend the First Amendment.").

184. Lidsky \& Garcia, supra note 59, at 716 n.130.

185. See N.Y. Times Co. v. United States, 403 U.S. 713 (1971) (per curiam).

186. Id. at 714 (first quoting Bantam Books, Inc. v. Sullivan, 372 U.S. 58, 70 (1963); then citing Near v. Minnesota ex rel. Olson, 283 U.S. 697, 718 (1931); and then quoting Org. for a Better Austin v. Keefe, 402 U.S. 415, 419 (1971)).

187. Id. (quoting Org. for a Better Austin, 402 U.S. at 419); see Scordato, supra note 158 , at 5,5 n. 14 . 
surrounds whether pre-trial publicity endangers a criminal defendant's fair trial enough to merit a court order. ${ }^{188}$

A second is obscenity. A generation ago, Professors Kauper, Emerson, and Schauer all classified the prior restraint doctrine as a division of the administrative control that authorities used to suppress obscene books and motion pictures. ${ }^{189}$ In the meantime, however, prior restraint analysis seems to have either faded or departed from contemporary obscenity control as advance licensing dropped into the sunset and as the rise of internet porn channeled the government's obscenity control into the criminal courts. ${ }^{190}$

In a third branch of prior restraints, parades and demonstrations, the prior restraint doctrine has been elbowed aside by executive licensing. Courts analyze executive licensing under the Legislature's and the Executive's decision-making power concerning time, place, and manner. ${ }^{191}$ " $[\mathrm{F}]$ or government to regulate speech activity before the fact, incident to a time, place, and manner scheme," Professor Ron Krotoszynski wrote, "is to say that government may enact prior restraints against speech that fails to meet the requirements of the regulatory rules." 192

Another branch of prior restraint, illustrated by New York Times Co. v. United States, known as the Pentagon Papers litigation in 1971, and United

188. See Neb. Press Ass'n. v. Stuart, 427 U.S. 539, 539-40 (1976) (holding that the trial court's order restraining media coverage leading up to a trial for multiple murders was unconstitutional under the First Amendment); In re Dan Farr Prods., 874 F.3d 590, 597 (9th Cir. 2017) (granting mandamus to reverse pretrial silence order in trademark infringement lawsuit); WPTA-TV v. State, 86 N.E.3d 442, 449 (Ind. Ct. App. 2017) (forbidding TV from broadcasting recording of sentencing was not a prior restraint or a violation of the First Amendment); Order at 1-2, United States v. Manafort, 897 F.3d 340 (D.C. Cir. 2018) (Crim. Action No. 17-0201). See Hunter, supra note 156, at 287-91 The headlines tell the story of a 2018 trial judge's mistaken silence order and his correction after learning of the error; Victoria Kim, Judge Lifts Controversial Order Requiring the L.A. Times to Alter Article About an Ex-Glendale Cop, L.A. TIMES (July 17, 2018, 6:20 PM), https:// www.latimes.com/local/lanow/la-me-ln-balian-order-lifted-20180717-story.html [https://perma. cc/4XDU-V25E]; Jennifer Medina, Judge Orders Los Angeles Times to Delete Part of Published Article, N.Y. Times (July 15, 2018) https://www.nytimes.com/2018/07/15/us/judge-losangeles-times-delete-article.html [https://perma.cc/F9XT-JYMR]; Debra Cassens Weiss, Federal Judge Issues Gag Order in Case Involving Manafort and Gates, A.B.A. J. (Nov. 8, 2017, 11:59 AM), http://www.abajournal.com/news/article/lawyers_comments_are_restricted in_manafort_case [https://perma.cc/Y3B4-XN3G].

189. See EMERSON, supra note 156, at 503-04, 507, 511; KAUPER, supra note 45, at 60-62, 82; FREDERICK F. SCHAUER, THE LAW OF OBSCENITY $§ 12.1$, at 230-32 (1976).

190. See generally United States v. Hashime, 734 F.3d 278 (4th Cir. 2013).

191. Ronald J. Krotoszynski, JR., Reclaiming the Petition Clause: Seditious Libel, “OFFEnSIVE” Protest, AND THE Right to PETITION the GovernMENT FOR A REDRESS OF GRIEVANCES 26 (2012).

192. Id. 
States v. Progressive, Inc. in 1978, is national security. ${ }^{193}$ The futility of an injunction to protect the government's secrets was apparent even then. ${ }^{194}$

In 2010, when WikiLeaks released sensitive national-security material, the authorities did not seriously consider an injunction. ${ }^{195}$ Edward Snowden turned National Security Agency (NSA) files over to newspapers, including to Barton Gellman at The Washington Post. ${ }^{196}$ Snowden is in Russia; if he returns to the United States, he is a candidate for a criminal prosecution for espionage. ${ }^{197}$ However, Gellman, who negotiated with the government as the material was published, told Terry Gross that his successful prosecution would require a broad interpretation of the espionage statute that lawyers think would violate free speech. ${ }^{198}$ Discussing another reporter, President Obama's Attorney General observed that "any journalist who's engaged in true journalistic activities is not going to be prosecuted by this Justice Department." 199 Apparently the government did not consider either an injunction or a criminal prosecution against either Gellman or The Washington Post. ${ }^{200}$ "The Internet's ability to cross national borders seamlessly and at a low cost concomitantly reduces the traditional power of nation-states to limit information distribution." ${ }^{201}$ Stay tuned. The Trump Administration, however, is hostile

193. N.Y. Times Co. v. United States, 403 U.S. 713, 713-14 (1971); United States v. Progressive, Inc., 467 F. Supp. 990, 990-91, 1000 (W.D. Wis. 1979).

194. See Bank Julius Baer \& Co. v. Wikileaks, 535 F. Supp. 2d 980, 982 (N.D. Cal. 2008); L.A. Powe, Jr., The H-Bomb Injunction, 61 U. CoLO. L. REV. 55, 71 (1990) (citing Howard Morland, The Secret that Exploded 202 (1981)).

195. Derek E. Bambauer, Consider the Censor, 1 WAKE Forest J.L. \& POL'Y 31, 37-38 (2011); Jerome A. Barron, The Pentagon Papers Case and the WikiLeaks Controversy: National Security and the First Amendment, 1 WAKE FOREST J.L. \& POL'Y 49, 67, 73 (2011).

196. Reporter Had to Decide if Snowden Leaks Were 'The Real Thing, 'NPR: FRESH AIR (Sept. 11, 2013), https://www.npr.org/templates/transcript/transcript.php?storyId=221 359323 [https://perma.cc/LT5K-QYLG].

197. Id.

198. Id.

199. Sari Horwitz, Justice Is Reviewing Criminal Cases that Used Surveillance Evidence Gathered Under FISA, WASH. POST (Nov. 15, 2013), https://www.washington post.com/world/national-security/justice-reviewing-criminal-cases-that-used-evidencegathered-under-fisa-act/2013/11/15/0aea6420-4e0d-11e3-9890-a1e0997fb0c0_story.html? noredirect $=$ on\&utm_term $=.0 \mathrm{bf} 36 \mathrm{bf} 7 \mathrm{fea} 5$ [https://perma.cc/W2VH-ADAV]. Attorney General Holder later said that "[a]s long as I'm attorney general, no reporter who is doing his job is going to jail." Charlie Savage, Holder Hints Reporter May be Spared Jail in Leak, N.Y. TIMES (May 27, 2014), https://www.nytimes.com/2014/05/28/us/holder-hints-reportermay-be-spared-jail-in-leak.html [http://perma.cc/9LK5-9MC7].

200. See David D. Cole, Assessing the Leakers: Criminals or Heroes?, 8 J. NAT'L SECURITY L. \& POL'y 107, 107-08 (2015).

201. Bambauer, supra note 195, at 35. 
to the press and reversing many of its predecessor's policies. ${ }^{202}$ As this Article was in the final stages of being prepared for publication, the Trump administration's indictment of Julian Assange for violation of the Espionage Act was a prosecution the Obama administration had declined because of free press concerns. ${ }^{203}$ Related areas include domestic and international cyberbullying, revenge porn, hate speech, privacy rights including data breaches, and sex trafficking online. Websites develop and refine measures to stop or delete improper contributions. ${ }^{204}$ Internet defamation removal is an industry and a law firm sub-specialty as a web-searcher learns quickly; it includes charlatans who sue impostor defendants to obtain improper orders to remove. ${ }^{205}$

These developments in hand, we can return to the defamation injunction as a prior restraint.

\section{THE CONTEMPORARY DEBATE: BALBOA ISLAND VILLAGE INN, INC. V. LEMEN AND KINNEY V. BARNES}

Like Jay Near, Anne Lemen was a pest. ${ }^{206}$ Distressed by her restaurantbar neighbor, the Balboa Island Village Inn, she referred to its employees and customers as "whores" and its food as "shitty."207 She publicly accused the Inn of closing hours, immigration violations, fostering child porn, prostitution, and lesbian activity. ${ }^{208}$ The Inn sued her for several substantive breaches, including defamation. ${ }^{209}$ The Inn sought an injunction. ${ }^{210}$ After a trial, the judge granted the Inn an injunction that, among other things, forbade Lemen from repeating several defamatory statements. ${ }^{211}$

202. See Margaret Sullivan, Shocked by Trump Aggression Against Reporters and Sources? The Blueprint Was Drawn by Obama, WASH. POST (June 8, 2018), https://www. washingtonpost.com/lifestyle/style/shocked-by-the-trump-aggression-against-reportersand-sources-the-blueprint-was-made-by-obama/2018/06/08/c0b84d88-6b06-11e8-9e3824e693b38637_story.html?utm_term=.cd2698bf7cd0 [https://perma.cc/NFT6-5KKC].

203. Charlie Savage, Assange Indicted Under Espionage Act, Raising First Amendment Issues, N.Y. TIMES (May 23, 2019), https://www.nytimes.com/2019/05/23/us/politics/ assange-indictment.html [https://perma.cc/54LT-35B9].

204. See, e.g., Community Guidelines, InSTAGRAM, https://help.instagram.com/477 434105621119 [http://perma.cc/2AFG-U9AJ].

205. Eugene Volokh \& Paul Alan Levy, Opinion, Dozens of Suspicious Court Cases, with Missing Defendants, Aim at Getting Web Pages Taken Down or Deindexed, WASH. POST (Oct. 10, 2016), https://www.washingtonpost.com/news/volokh-conspiracy/wp/2016/ 10/10/dozens-of-suspicious-court-cases-with-missing-defendants-aim-at-getting-web-pagestaken-down-or-deindexed/?utm term=.41d5510caa43 [https://perma.cc/MXX9-ZU2L].

206. See Balboa Island Vill. Inn, Inc. v. Lemen, 156 P.3d 339, 341 (Cal. 2007)

207. Id.

208. Id. at $341-42$.

209. Id. at 342

210. Id.

211. Id. 
The California Supreme Court held that the trial judge's injunction was too broad and dissolved it. ${ }^{212}$ "[B] ut," the majority wrote, "a properly limited injunction prohibiting defendant from repeating to third persons statements about the Village Inn that were determined at trial to be defamatory would not violate defendant's right to free speech." 213

The Texas Supreme Court's 2014 decision in Kinney v. Barnes is an important contrary opinion that rejects the California court's reasoning. ${ }^{214}$ The Texas Supreme Court held that damages are the appropriate remedy for defamation in that state. ${ }^{215}$ A plaintiff's damages judgment for defamation is the prior restraint doctrine's favored subsequent punishment. ${ }^{216}$

Kinney sued his former employer, Barnes, for defamation after the Barnes allegedly defamed him on the internet by accusing him of paying bribes. ${ }^{217}$ The injunction Kinney sought had two features: first, to remove the alleged defamation, a take-down order; and, second, to forbid Barnes from repeating it. $^{218}$ Kinney argued that the court should treat defamation as unprotected expression that is subject to an injunction like obscenity and commercial speech. $^{219}$

Although the lower Texas courts had dismissed Kinney's complaint, the state's Supreme Court reinstated it. ${ }^{20}$ The take-down order was not, the court held, a prior restraint; if Kinney proved his case, the judge could employ it. ${ }^{221}$ However, an injunction to forbid defendant's future defamation fell under the no-injunction Maxim that the court located in the Texas State Constitution. ${ }^{222}$ The judge should not grant an injunction against unprotected speech - defamation - if that injunction would chill future protected speech. ${ }^{223}$ A judge may grant an injunction that is a prior restraint only to avoid danger. ${ }^{224}$ Finding that the changes wrought by the internet did not alter the

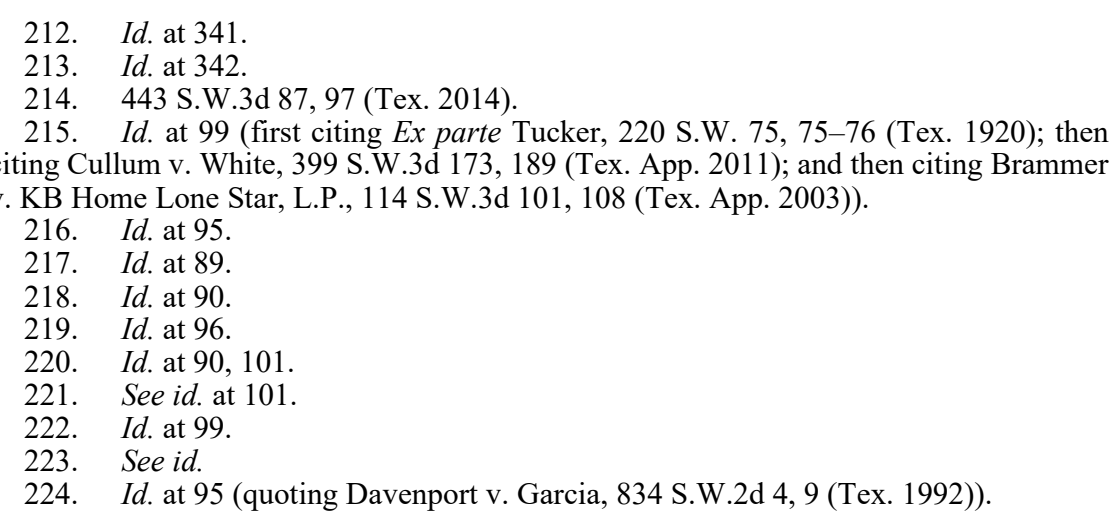


level of protection afforded to speech, the Texas Supreme Court retained the Maxim that "Equity will not enjoin libel." 225 As the Texas court held, prior restraint rubric and the no-injunction Maxim counsel the court to prefer damages, the putative subsequent punishment, to the prior restraint, the injunction. 226 In short, the Texas court disapproved the identical injunction that the California court had approved.

The Balboa court's and the Kinny court's reasoning will emerge below as this Article continues its principal inquiry: What deference should the judge extend to the defendant's expression when the plaintiff seeks an injunction to forbid the defendant's defamation?

\section{DAMAGES AND INJUNCTIONS}

Setting aside executive licensing and a criminal prosecution for libel because they are, as we observed above, unlikely, this Article will analyze whether the time is ripe for other courts to pick up the Balboa court's cue and grant an injunction to protect a successful defamation plaintiff.

An injunction is the prior restraint; a damages judgment is the subsequent punishment.

\section{A. Defamation Damages}

We begin with the murky subject of defamation damages. This subject is complex and contradictory because of several variables and distinctions in federal constitutional law, state common law, and state constitutional law. ${ }^{227}$ In defamation, presumed general damages are compensatory damages for the plaintiff's non-pecuniary general losses of reputation, shame, mortification, humiliation, loss of standing in the community, emotional distress, and mental suffering. ${ }^{228}$ The jury may presume these damages and award them to the plaintiff without the plaintiff presenting any evidence. ${ }^{229}$

225. See id. at $95,101$.

226. Id. at 100 (quoting Milkovich v. Lorain Journal Co., 497 U.S. 1, 22-23 (1990)); see Chevaldina v. R.K./FL Mgmt., Inc., 133 So. 3d 1086, 1090 (Fla. Dist. Ct. App. 2014) (declining to issue an injunction for defamation unless the defamation was made in furtherance of another intentional tort).

227. See Mike Steenson, Presumed Damages in Defamation Law, 40 WM. Mitchell L. REV. 1492, 1494 (2014).

228. See id. at 1502-03 (quoting Judicial Council of California Civil Jury INSTRUCTIONS 1704 (2018)).

229. Bierman v. Weier, 826 N.W.2d 436, 454 (Iowa 2013) (quoting Dun \& Bradstreet, Inc. v. Greenmoss Builders, Inc., 472 U.S. 749, 760-61 (1985)); RESTATEMENT (SECOND) OF TORTS $\S 559 \mathrm{cmt}$. d (AM. LAW INST. 1977) (stating that no actual harm is necessary to state a cause of action for defamation); id. $\S 570$ (discussing recovery without proving actual injury). A state may go beyond the Sullivan decisions and abolish the doctrine of presumed damages. 3 DOBBS, HAYDEN \& BUBLICK, supra note 7, $\S 574$, at 336 . For example, 
Second, the plaintiff may recover proved injury to his reputation plus emotional distress. ${ }^{230}$ If people believed the defendant's falsehood and shunned the plaintiff's business, the plaintiff may recover compensatory damages for pecuniary losses like lost employment or lost business. ${ }^{231}$ The plaintiff may recover for the expense of defending his or her reputation with, for example, corrective advertising. ${ }^{232}$

Third, the plaintiff may recover punitive damages if the defendant's misconduct exceeds the jurisdiction's misconduct threshold, reckless disregard, implied malice, or actual malice. ${ }^{233}$ The defendant's knowing or reckless falsehood may trigger a punitive damages judgment to punish and deter the behavior. ${ }^{234}$

The Supreme Court has blended the Sullivan principles with the damages measures. In a private plaintiff's libel action, the United States Constitution does not bar punitive damages or presumed damages. ${ }^{235}$ If the plaintiffs prove that their defendants knowingly or recklessly published a falsehood, the plaintiffs may recover presumed general damages to their reputation plus punitive damages. ${ }^{236}$ The result is complex and subtle. A private plaintiff defamed on a matter of private or no-public concern may recover presumed general damages to reputation and punitive damages. ${ }^{237}$ A private plaintiff defamed on a matter of public concern must show defendant's negligence or more serious fault to recover compensatory damages. ${ }^{238}$ A court may impose damages liability for a defendant's defamatory falsehood about a private individual regarding a matter of public concern if the defendant made

in New Mexico, a plaintiff's prima facie case for defamation must include proof of actual injury to reputation, proof of humiliation, and anguish. Smith v. Durden, 276 P.3d 943, 951 (N.M. 2012); see also Steenson, supra note 227, at 1492.

230. Kinney, 443 S.W.3d at 99 (citing Hancock v. Variyam, 400 S.W.3d 59, 65-66 (Tex. 2013)).

231. See Hancock, 400 S.W.3d at 65-66.

232. See 3 DOBBS, HAYDEN \& BUBLICK, supra note $7, \S 574$, at 338.

233. Kinney, 443 S.W.3d at 99 (citing Hancock, 400 S.W.3d at 65-66); 3 DobBS, HAYDEN \& BUBLICK, supra note 7, § 574, at 338-41 (first citing Den Norske Ameriekalinje Actiesselskabet v. Sun Printing \& Publ'g Ass'n, 122 N.E. 463, 464 (N.Y. 1919); and then citing Prozeralik v. Capital Cities Commc'ns, Inc., 626 N.E.2d 34, 48 (N.Y. 1993)); see 1 Robert D. SAck, Sack On Defamation: Libel, Slander, AND Related Problems $\S$ 10:3.5, at 10-24 to -25 (5th ed. 2018); Anderson, Tortious, supra note 64, at 77-79.

234. See, e.g., Dun \& Bradstreet, 472 U.S. at 751; Gertz v. Robert Welch, Inc., 418

U.S. 323, 349 (1974); Volokh, supra note 2 (manuscript at 8 n.20).

235. See, e.g., Kinney, 443 S.W.3d at 99.

236. Gertz, 418 U.S. at 349.

237. See Herbert v. Lando, 441 U.S. 153, 160 (1979).

238. See id. 
the statement negligently and it caused actual injury to the plaintiff's reputation or if defendant made it with "knowledge of [its] falsity or reckless disregard for the truth." ${ }^{239}$ A plaintiff who proves only the defendant's negligence may recover neither presumed general damages to his reputation nor punitive damages. ${ }^{240}$

Justice Brennan expressed the policy base in a two-metaphor phrased Defamation law affords "breathing space" to a defendant's falsity to prevent "chilling" other later potential speakers. ${ }^{241}$

Some policy and some clarity emerge from one court's response to a defendant's argument that the plaintiff's presumed damages for "mental suffering, personal humiliation, and impairment of personal and professional reputation and standing in the community without evidence assigning a monetary value to the injury" bar punitive damages because presumed damages plus punitive damages comprise an impermissible double recovery. ${ }^{242}$ Both, defendant reasoned, consist of "unquantifiable elements resulting from damaged reputation." 243

The court rejected the defendant's argument, in effect, that presumed damages, general damages to reputation, are punitive. ${ }^{244}$

[I]t is often extremely difficult, if not impossible, for the average plaintiff in such an action to present evidence which would support an award of compensatory damages based upon the actual harm sustained. Presumed damages are similar to the general damages awarded a personal injury plaintiff for the pain, suffering and disability resulting from an injury. ${ }^{245}$

From the fact that the plaintiff was injured by the defendant's tort, the judge lets the jury assume that presumed general damages or pain and suffering occurred.

"[C]ompensation," moreover, the court continued, "is not the purpose of punitive damages." 446 Punitive damages punish and deter wrongdoers, but presumed damages compensate victims. The defendant's misconduct may call for punishment over and above an award of compensatory damages.

239. Gertz, 418 U.S. at 348-49; see Herbert, 441 U.S. at 160; FREDERICK SCHAUER, Free SPEeCH: A PHILOSOPHICAL ENQUIRY 171 (1982).

240. Anderson, Tortious, supra note 64, at 78 .

241. McDonald v. Smith, 472 U.S. 479, 486-87 (1985) (Brennan, J., concurring); N.Y. Times Co. v. Sullivan, 376 U.S. 254, 271-72 (1964) (quoting NAACP v. Button, 371 U.S. 415, 433 (1963)).

242. Winters v. Greeley, 545 N.E.2d 422, 427 (Ill. App. Ct. 1989).

243. Id.

244. Id. at 427-28.

245. Id.

246. Id. at 428 . 
Punitive damages in addition to compensatory damages do not "constitute an impermissible double recovery."247

A major part of many defamation plaintiffs' compensatory damages comprises of damages for emotional distress and lost reputation. A defamation plaintiff may recover punitive damages, which are explicitly based on policies of punishment and deterrence. ${ }^{248}$ How accurate is it to call defamation damages punishment to qualify as subsequent punishment under the prior restraint rule? Compensatory damages compensate and deter, but they are not called punishment. If the preferred alternative to the prior restraint of an injunction is the subsequent punishment of damages, then only punitive damages are purely punishment. The other forms of damages recovery are compensatory damages with, at best, a shaky claim to be punishment.

Defamation damages have been controversial. ${ }^{249}$ In a movement called tort reform, actual and potential tort defendants favor measures that eliminate their potential liability or reduce its consequences. ${ }^{250}$ Quite a bit of tort reform is damages reform. Under the banner of free speech and the First Amendment, the arguments that assail defamation damages include a lot of standard tort-reform rhetoric: There is too much liability. Damages are too high. And juries are out of control. ${ }^{251}$

Critics assert that defamation damages are surrogate punitive damages: "Compensatory damages for defamation are already highly subjective and may even contain a hidden punitive component. To permit additional punitive damages, therefore, may punish the defendant twice and provide the plaintiff with a windfall grossly out of proportion to actual injury." 252

Just as modern-day tort reformers attack personal injury plaintiffs' damages for pain and suffering, defamation reformers assail non-pecuniary compensatory damages for defamation as imprecise, unpredictable, and potentially crushing.

247. Id. at 429 .

248. See Anderson, Reforming, supra note 81, at 522-23.

249. See generally, Sheldon W. Halpern, Values and Value: An Essay on Libel Reform, 47 WASH. \& LEE L. REV. 227 (1990) (arguing that this controversy stems in part from the actions of juries awarding damages).

250. See e.g., Michael L. Rustad \& Thomas H. Koenig, Taming the Tort Monster: The American Civil Justice System as a Battleground of Social Theory, 68 BROOK. L. REV. 1, 3-4, 7 (2002).

251. See generally id.

252. Rodney A. Smolla et al., Annenberg Wash. Program, Proposal for the Reform of Libel Law: The Report of the Libel Reform Project OF the ANNENBERG WASHINGTON PROGRAM 25 (1988). 
State tort-reform capping statutes apply to defamation damages. ${ }^{253}$ Justice White concurring in Dun \& Bradstreet, Inc. v. Greenmoss Builders, Inc. wrote that limiting the damages that the plaintiff could recover may be wiser because presumed damages to reputation and punitive damages are particularly questionable. ${ }^{254}$ Dissenting in Rosenbloom v. Metromedia, Justice Marshall favored limiting a private-figure libel plaintiff to only actual damages. ${ }^{255}$

Anderson's proposal to reform defamation damages maintained that presumed general damages should be eliminated completely. ${ }^{256}$ A defamation plaintiff could recover for an injured reputation or emotional harm only if the plaintiff proved an actual loss. ${ }^{257}$ Another defamation reformer, Professor Halpern, maintained that "although equipped to deal with life and liberty, the jury's hands are too indelicate to be entrusted with matter touching on a fragile [F]irst [A]mendment."258 Plaintiffs' recoveries of "apparently openended and unstructured awards of presumed damages are at the center of the antipathy toward the jury." 259 He argued that presumed damages and punitive damages should be eliminated in defamation, except to allow punitive damages based on clear and convincing evidence of intent to harm. ${ }^{260}$

Van Alstyne argued that the threat of punitive damages chills expression so much that they should be abolished. ${ }^{261}$ Professor Barron responded that the possibility of punitive damages empowers the "individual plaintiff to transform himself from David to Goliath." 262

Punitive damages, it was said, are "an excessive chill on free expression and may be devastating to defendant." 263 They "bear no relation to reality, sometimes serving to vent distaste for the nature or character of the defendant

253. See, e.g., Anderson v. Hebert, 830 N.W.2d 704, 704, 710 (Wis. Ct. App. 2013) (citing Wis. STAT. ANN. § 893.80(3) (West 2019)) (capping judgment against a government employee).

254. 472 U.S. 749, 771-72 (1985) (White, J., concurring).

255. Rosenbloom v. Metromedia, Inc., 403 U.S. 29, 84 (1971) (Marshall, J., dissenting).

256. See Anderson, Reforming, supra note 81, at 490.

257. See id. at 542-43, 547; David A. Anderson, Reputation, Compensation, and Proof, 25 WM. \& MARY L. REV. 747, 774-75 (1984); Anderson, Tortious, supra note 64, at $79-82$.

258. Halpern, supra note 249, at 247.

259. Id. at 243

260. Id. at $245,247,249$.

261. Van Alstyne, supra note 66, at 808-09; see Anderson, Reforming, supra note 81, at $542-43$.

262. Jerome A. Barron, Punitive Damages in Libel Cases—First Amendment Equalizer?, 47 WASH. \& LEE L. REV. 105, 122 (1990).

263. Id. at 115 (quoting SMOLLA ET AL., supra note 252, at 25). 
instead of fulfilling any rational interest in deterrence."264 Punitive damages may be abolished by a state constitution ${ }^{265}$ or statute. ${ }^{266}$

Judicial tort reform through the Sullivan line of decisions was the most important defamation reform. ${ }^{267}$ Judge Sack, the author of the leading book on defamation, asked whether the Sullivan rules "worked":

My impression, and it is no more than that - albeit in light of my reading of many, many appellate cases in this area decided since Sullivan - is that, overall and with some remarkable exceptions, it has. The press's reporting on public figures appears to be largely free from intimidation by the threat of defamation lawsuits. 268

The reforms eventually succeeded. ${ }^{269}$ Also, beginning in the 1990 s, the Supreme Court began judicial tort reform of punitive damages under the United States Constitution's Fourteenth Amendment's Due Process Clause. ${ }^{270}$

Baldder is a private, not a public, plaintiff. He is suing Lokki, a private defendant. The subject of Lokki's liability is either her intentional private criticism or the "public" issue of consumer protection. ${ }^{271}$ If Baldder makes it to the end of the libel litigation labyrinth, Lokki's intentional, perhaps malicious, libel will likely qualify Baldder to recover his pecuniary losses, presumed general compensatory damages to his reputation, and perhaps punitive damages to punish Lokki.

264. SMOLLA ET AL., supra note 252, at 25.

265. E.g., Stone v. Essex Cty. Newspaper, Inc., 330 N.E.2d 161, 169 (Mass. 1975) (citing Gertz v. Robert Welch, Inc., 418 U.S. 323, 349 (1974)); Wheeler v. Green, 593 P.2d 777, 788-89 (Or. 1979).

266. Brantley v. Zantop Int'l Airlines, Inc., 617 F. Supp. 1032, 1035-36 (E.D. Mich. $1985)$.

267. 3 DoBBS, HAYDEN \& BUBLICK, supra note 7, § 577, at 349.

268. Sack, supra note 85, at 288.

269. Ardia, supra note 1, at 11 \& nn.31-32 (first citing John Koblin, The End of Libel?, OBSERVER (June 9, 2010, 1:23 AM), https://observer.com/2010/06/the-end-of-libel/ [https://perma.cc/GGV3-FALD]; and then citing Eric P. Robinson, The End of Libel? Or Just Libel Trials?, BLOG L. ONLINE (June 22, 2010), https://bloglawonline.blogspot.com/ 2010/06/end-of-libel-or-just-libel-trials.html [https://perma.cc/ZX4J-GAS4]).

270. See, e.g., Exxon Shipping Co. v. Baker, 554 U.S. 471, 499-502, 506 (2008); Philip Morris USA v. Williams, 549 U.S. 346, 349-53 (2007); BMW of N. Am., Inc. v. Gore, 517 U.S. 559, 559 (1996); see also Doug Rendleman, A Plea to Reject the United States Supreme Court's Due-Process Review of Punitive Damages, in THE LAW OF REMEDIES: New Directions in the Common Law 533, 534-36 (Jeff Berryman \& Rick Bigwood eds., 2010); Doug Rendleman, Common Law Punitive Damages: Something for Everyone?, 7 U. St. Thomas L.J. 1, 9-15 (2009).

271. See Turf Lawnmower Repair, Inc. v. Bergen Record Corp., 655 A.2d 417, 428 (N.J. 1995) (finding that consumer fraud is a public issue). 
Do the differences between an injunction and damages mean that a court should favor the plaintiff's damages recovery and disfavor his injunction? This Article turns to the ways the injunction remedy differs from the damages remedy. ${ }^{272}$ It will discuss several ways an injunction differs from damages: the inadequacy prerequisite, preventive relief, interlocutory relief, juryless procedure, drafting an injunction, motions to modify-dissolve an injunction, and contempt. In a little more detail, a judge's decision to grant a plaintiff an injunction differs from the decision to award a plaintiff damages: To receive an injunction, first, the plaintiff must show inadequacy-irreparability. ${ }^{273}$ Second, a successful plaintiff receives an injunction that is preventive relief. Third, the judge may grant a deserving plaintiff an interlocutory injunction before the plenary trial. ${ }^{274}$ Fourth, the process leading to an injunction will not include a jury. ${ }^{275}$ Fifth, the judge must draft an injunction. After drafting and entering an injunction, the judge must administer it, which takes two paths. ${ }^{276}$ Sixth, when an injunction is in effect, either the defendant or the plaintiff may move to modify or dissolve it. ${ }^{277}$ Seventh, when the defendant violates an injunction, contempt will be the remedy. ${ }^{278}$ A plaintiff's damages judgment for a sum of money, on the other hand, enables the plaintiff to collect from the defendant's assets, in the absence of voluntary payment, through the impersonal techniques of execution, garnishment, and judgment lien. ${ }^{279}$ The judge ought to grant a defamation plaintiff an injunction with the differences and consequences in mind.

\section{B. Inadequacy-Irreparability}

One prerequisite for granting a plaintiff an injunction is the plaintiff's demonstration that the remedy at law, here damages, will be inadequate and that without an injunction, the defendant's wrong will cause him irreparable injury. ${ }^{280}$ The judge grants the plaintiff an injunction to shield the plaintiff's interests that he ought to be able to enjoy in fact because money will be an inadequate substitute for those rights.

272. First Amendment scholars may refer to the difference between the damages and injunction remedies as a difference in form. See EMERSON, supra note 156, at 504. This Article uses more specific and descriptive remedies vocabulary.

273. eBay Inc. v. MercExchange, L.L.C., 547 U.S. 388, 391 (2006).

274. E.g., Zant v. Dick, 249 S.E.2d. 508, 509 (Ga. 1982).

275. See infra Section IV.E.

276. See infra Section IV.D.

277. See Fed. R. Civ. P. 65(b)(4).

278. See generally RENDLEMAN, supra note 146, at chs. 8-12.

279. See generally Doug RENDLEMAn, ENFORCEMENT OF JUDGMENTS AND LIENS IN VIRGINIA chs. 3-5 (3d ed. 2014).

280. eBay Inc. v. MercExchange, L.L.C., 547 U.S. 388, 391 (2006). 
In eBay v. MercExchange, the Supreme Court established what it called a traditional four-point test. ${ }^{281}$

The first two of the eBay Court's four points are that plaintiffs must show that they are at risk of an irreparable injury and that damages will be an inadequate remedy. ${ }^{282}$ This Article combines the two tests that the Court stated separately because, as a practical matter, the two tests are similar, if not identical. Unfortunately, the Court left lawyers and trial judges at large by not giving any context to the eBay test. As the eBay test works its way through the process, however, its consequences have been deleterious to plaintiffs seeking injunctions. ${ }^{283}$

To some extent, contemporary courts' preference for money damages "persists today." 284 The reason the Virginia Supreme Court gave to disapprove the plaintiff's interlocutory injunction in Perez v. Dietz Development, LLC was that damages were an adequate remedy. ${ }^{285}$

But are damages really a satisfactory and adequate remedy for a defamation plaintiff? A defamation plaintiff, like our hypothetical Baldder, will likely undergo emotional distress, lost business, and general damages to reputation. ${ }^{286}$ Since a defamation plaintiff does not encounter lost reputation or emotional distress in money, a jury or a judge will be challenged to value the plaintiff's loss and to convert it to money. A business plaintiff's impaired reputation

281. Id. at 394. With respect, many remedies scholars, including this author, maintain that the Court ignored more than a generation of cogent scholarly criticism of the irreparable injury rule. See Fiss, supra note 160; Douglas Laycock, The Death of THE IrREPARABLE INJURY RUle (1991); Doug Rendleman, Irreparability Resurrected?: Does a Recalibrated Irreparable Injury Rule Threaten the Warren Court's Establishment Clause Legacy?, 59 WASH. \& LEE L. REV. 1343 (2002) [hereinafter Rendleman, Irreparability]. For criticism, see RENDLEMAN, supra note 146, at 86; Mark P. Gergen, John M. Golden \& Henry E. Smith, The Supreme Court's Accidental Revolution? The Test for Permanent Injunctions, 112 COLUM. L. Rev. 203, 204 (2012).

282. eBay Inc., 547 U.S. at 391. The other two points that the eBay Court tells an injunction plaintiff to demonstrate are that the balance of hardships and the public interest favor granting him an injunction. $I d$.

283. See Thomas F. CotTer, Comparative Patent Remedies: A Legal AND ECONOMIC ANALYSIS 102-03 (2013); Gergen, Golden \& Smith, supra note 281, at 234; Christopher B. Seaman, Permanent Injunctions in Patent Litigation After eBay: An Empirical Study, 101 IowA L. REV. 1949, 1983-84 (2016).

284. Ardia, supra note 1, at 24-25; see Kinney v. Barnes, 443 S.W.3d 87, 99, 101 (Tex. 2014).

285. No. 122157, 2012 WL 6761997, at*1 (Va. Dec. 28, 2012); see also Metro. Opera Ass'n v. Local 100, Hotel Emps. \& Rest. Emps. Int'l Union, 239 F.3d 172, 177 (2d Cir. 2001) ("[I]njunctions are limited to rights that are without an adequate remedy at law ....").

286. 3 DoBBS, HAYDEN \& BUBLICK, supra note 7, § 574, at 336-40. 
may generate business losses, but a plaintiff's lost future business profits are notoriously difficult to prove and recover. ${ }^{287}$ Money does not restore, an injunction prevents. "Glass, China, and Reputation, are easily crack'd, and never well mended," observed Poor Richard. ${ }^{28}$ " [T] he [object of defamation's] ability to respond through the media will depend on the same complex factor on which the ability of a private individual depends: the unpredictable event of the media's continuing interest in the story," Justice Brennan wrote. ${ }^{289}$ In the legal profession's modern jargon, a court cannot monetize a plaintiff's interest in reputation because the values are incommensurable. ${ }^{290}$

The defendant may be insolvent, unable to pay damages, a factor that observers consider to support a court's decision to grant the plaintiff an injunction. ${ }^{291}$ The majority in Balboa maintained that damages do not affect either a pauper or a millionaire because the pauper cannot pay at all and the millionaire can pay without any deterrent effect. ${ }^{292}$ The Texas court explicitly rejected that point; it maintained that the defendant's economic status should not change the plaintiff's remedy. ${ }^{293}$

The inadequacy of damages and the irreparability of the plaintiff's injury from a defendant's defamation are palpable under Professor Laycock's view that the judge should grant the plaintiff an injunction unless he could take the money-damages judgment and buy the equivalent of his impaired interest. ${ }^{294}$ A plaintiff's reputation and emotional distress are not for sale. Neither the plaintiff's reputation nor the plaintiff's emotional distress is impaired in money terms. Neither can be replaced by money.

If the factfinder does measure damages to reputation and emotional distress in money, both are uncertain and speculative. "Both because the thing lost is

287. See, e.g., Mindgames, Inc. v. W. Publ'g Co., 218 F.3d 652, 654-55, 658 (7th Cir. 2000); Balboa Island Vill. Inn, Inc. v. Lemen, 156 P.3d 339, 358 (Cal. 2007); Saks Fifth Ave., Inc. v. James, Ltd., 630 S.E.2d 304, 310-13 (Va. 2006); see also Erwin Chemerinsky, Injunctions in Defamation Cases, 57 SYRACUSE L. REV. 157, 170 (2007) (identifying the plaintiff's difficulty of measuring and proving damages from defamation).

288. BENJAMIN Franklin, PoOR RichaRD's Almanack 51 (Peter Pauper Press, Inc., 1986).

289. Rosenbloom v. Metromedia, Inc., 403 U.S. 29, 46 (1971).

290. Margaret JeAn Radin, Contested Commodities 184-206 (1996).

291. See Cornwell v. Sachs, 99 F. Supp. 2d 695, 703 (E.D. Va. 2000); LAYCOCK, supra note 281, at 75-76; Ardia, supra note 1, at 26 \& n.105 (first citing Willis v. O'Connell, $231 \mathrm{~F}$. 1004, 1014 (S.D. Ala. 1916); and then citing Willing v. Mazzocone, 393 A.2d 1155, 1159 (Pa. 1978)); Chemerinsky, supra note 287, at 170. But see Willing, 393 A.2d at 1158 (deciding not to issue an injunction against an insolvent defendant's defamation because damages were an adequate remedy).

292. See Balboa Island Vill. Inn, 156 P.3d at 358.

293. Kinney v. Barnes, 443 S.W.3d 87, 100 (Tex. 2014) (quoting Willing, 393 A.2d at 1158).

294. LAYCOCK, supra note 281, at 37. 
irreplaceable and because the loss is hard to measure," Laycock wrote, "damages are a seriously inadequate remedy for defamation.",295

Under any irreparability-inadequacy test, the judge must decide whether to stand aside and watch the defendant inflict harm on the plaintiff's reputation, only to award the plaintiff a money substitute later. Bringing the inquiry into the wireless world, Professor Ardia asks whether a defamation plaintiff needs an injunction even more in the internet age. ${ }^{296}$ A negative answer came from the Texas court: The internet doesn't change the plaintiff's preferred money-damages remedy for defendant's defamation. ${ }^{297}$

Money damages will usually be inadequate to compensate a defamation plaintiff's unpredictable lost reputation and emotional distress, as well as an unprovable future lost business. ${ }^{298}$ The plaintiff will not encounter lost reputation and emotional distress in money. These damages are difficult for a court to convert to money, showing that money will normally be an inadequate remedy. ${ }^{299}$ By the usual standards, a defamation plaintiff's damages remedy is inadequate. Without an injunction, a plaintiff will encounter irreparable injury. ${ }^{300}$

\section{Preventive Relief}

To safeguard the plaintiff's perishable rights, the judge grants the preventive remedy of an injunction that looks to the future to halt or forbid the defendant from harming the plaintiff. ${ }^{301}$ In contrast, money damages are retrospective. ${ }^{302}$ They compensate the plaintiff after an injury by substituting money for the defendant's past harm to the plaintiff's interest. ${ }^{303}$

The defendants' side of the plaintiffs' preventive coin is that an injunction, even one to refrain, circumscribes her liberty, range of possible conduct, activity, or like here, expression. In our hypothetical, the judge's injunction will limit Lokki's ability to excoriate Baldder with falsehoods.

295. Id. at 165 .

296. Ardia, supra note 1, at 4-6.

297. Kinney, 443 S.W.3d at 100-01.

298. See Mindgames, Inc. v. W. Publ'g Co., 218 F.3d 652, 658 (7th Cir. 2000);

LAYCOCK, supra note 281, at 165.

299. See LAYCOCK, supra note 281, at 165.

300. See Bertelsman, supra note 157, at 322; Estella Gold, Does Equity Still Lack Jurisdiction to Enjoin a Libel or Slander?, 48 BROOK. L. REV. 231, 259 (1982).

301. See IT Corp. v. Cty. of Imperial, 672 P.2d 121, 125 (Cal. 1983).

302. Republic of Para. v. Allen, 134 F.3d 622, 628 (4th Cir. 1998).

303. See id. 
A preventive injunction is not punishment. ${ }^{304}$ Ardia wrote that an injunction is a "coercive sanction." 305 Coercive is correct because an injunction's threat of contempt will structure its defendant's incentive to respect the plaintiff's rights. ${ }^{306}$ An injunction forbids a defendant's future activity at peril of contempt for a breach, to say it is a sanction is, however, premature. The sanction will be contempt, perhaps criminal contempt, which comes later after the defendant violates the injunction. ${ }^{307}$ The judge will not punish injunction defendants unless they are convicted of criminal contempt. ${ }^{308}$

Defamation victims cannot rely on counter speech to repair the damages a false statement causes to their reputation. "A lie gets half way around the world before the truth has a chance to get its pants on," is sometimes attributed to Winston Churchill. ${ }^{309}$ If the plaintiff's damages remedy is inadequate, the plaintiff needs an injunction's preventive relief.

\section{Interlocutory Relief}

A plaintiff's interlocutory injunction counters the axiom of litigation that delay is the defendant's friend. To protect the plaintiff expeditiously from irreparable injury, the judge follows incomplete procedure short of a plenary trial. $^{310}$

To persuade the judge to grant an interlocutory preventive relief, an injunction, plaintiff alleges the defendant's imminent or ongoing irreparable injury to an interest that the plaintiff alleges he has a right to enjoy in fact and that cannot be compensated with money. ${ }^{311}$ If the judge finds that damages are an inadequate remedy, the judge may take procedural shortcuts to hasten to protect the plaintiff's interest with an interlocutory order before a full hearing. ${ }^{312}$ The judge suspends the procedural stages of pleading and discovery to protect the plaintiff from the defendant's course of interlocutory irreparable injury. ${ }^{313}$

304. Hecht Co. v. Bowles, 321 U.S. 321, 329 (1944) (saying that an injunction deters, prevents future violations, but does not punish).

305. Ardia, supra note 1, at 61 .

306. See id.

307. See United States v. United Mine Workers of Am., 330 U.S. 258, 295 (1947).

308. Id. at 295-97.

309. Marianne M. Jennings, The Role of the Teaching Scholar in Politically Charged Times, 3 U. PA. J.L. \& PUB. AfF. 191, 203 \& n.37 (2018). Professor Anderson refers to a public figure's self help or reply as an unsatisfactory alternative. See Anderson, Reforming, supra note 81 , at 526 .

310. See Merrill Lynch, Pierce, Fenner \& Smith v. Bennert, 980 F. Supp. 73, 76 (D. Me. 1997).

311. See eBay Inc. v. MercExchange, L.L.C., 547 U.S. 388, 391 (2006).

312. See, e.g., Doug Rendleman \& CAPrice L. Roberts, Remedies: Cases AND MATERIALS 360 (9th ed. 2018).

313. RENDLEMAN \& ROBERTS, supra note 312, at 319, 360. 
Although the inadequacy-irreparability tests for interlocutory and final injunctive relief use the same words, the prerequisite that courts actually administer to consider a plaintiff's motion for an interlocutory order is more demanding. ${ }^{314}$ Judges are stingy with injunctions at the interlocutory stage, yet they are more generous at the final stage. "[C]ourts at the preliminary [injunction] stage routinely find that damages will be an adequate remedy for injuries they would consider irreparable after a full trial." 315 Because the judge grants an interlocutory injunction after incomplete procedure that risks error, judges may find lack of irreparable injury to reject an interlocutory injunction that they would be quite likely to grant as a final injunction after plenary trial. ${ }^{316}$

The federal procedural system and the states that have adopted the federal rules know two kinds of interlocutory orders: the temporary restraining order (TRO) and the preliminary injunction. ${ }^{317}$ Plaintiffs will file many, if not most, internet defamation lawsuits in state courts. ${ }^{318}$ Defamation is a state common law tort. ${ }^{319}$ If the defendant and the plaintiff live in the same state, diversity of citizenship to file in, or remove to, federal court will be absent. ${ }^{320}$ The defendant's federal defense, that the plaintiff's injunction would be a prior restraint that violates the First Amendment, does not create a federal question for federal jurisdiction. ${ }^{321}$ The plaintiff may file suit in the federal court's diversity jurisdiction, or the defendant may remove a state lawsuit to federal court; if so, the federal court should follow federal procedure, including Rule 65 , respect the state substantive defamation law, and decide the defendant's federal First Amendment defense. ${ }^{322}$

314. See 14859 Moorpark Homeowner's Ass'n v. VRT Corp., 74 Cal. Rptr. 2d 712, 715-16 (Ct. App. 1998).

315. LAYCOCK, supra note 281, at 113; see JAMES M. FISCHER, UNDERSTANDING REMEDIES $\$ 33.2$, at 288 (3d ed. 2014).

316. See Merrill Lynch, Pierce, Fenner \& Smith v. Bennert, 980 F. Supp. 73, 75-76

(D. Me. 1997); LAYCOCK, supra note 281, at 111-14, 117.

317. See FED. R. CIV. P. 65.

318. See generally Gertz v. Robert Welch, Inc., 418 U.S. 323, 369-70 (1974) (White, J., dissenting).

319. Organovo Holdings, Inc. v. Dimitrov, 162 A.3d 102, 114 (Del. Ch. 2017).

320. See 28 U.S.C. $\$ 1332$ (2012).

321. See id. $§ 1331$ (2012); Geofrrey C. Hazard, JR., John LeubSDORF \& DeBra Lyn Bassett, Civil Procedure $§ 2.4$, at 65 (6th ed. 2011); Charles Alan Wright \& Mary Kay Kane, LAW OF Federal Courts $\S 18$, at 111 (8th ed. 2017).

322. See generally McKee v. Cosby, 236 F. Supp. 3d 427 (D. Mass. 2017), aff'd, 874 F.3d 54 (1st Cir. 2017); Hanna v. Plumer, 380 U.S. 460 (1965). 
Although many states have adopted the federal rules, some states' interlocutory injunction terminology varies. ${ }^{323}$ The points and citations herein employ the federal terms but apply also to state courts with appropriately adjusted terminology. Lex, the forum for Baldder v. Lokki, has adopted the Federal Rules of Civil Procedure for its state courts.

Ex parte procedure, where the judge grants the plaintiff a TRO based on only the plaintiff's verified allegations and affidavits or declarations, is contemplated under state systems and the federal rule. ${ }^{324}$ However, the Supreme Court has required more procedural protection when the defendant's activity is speech- or expression-related. ${ }^{325}$

In Carroll v. Princess Anne, the Supreme Court struck down a Maryland state judge's ex parte order against the defendants' rally or public meeting in stating:

The 10-day order here must be set aside because of a basic infirmity in the procedure by which it was obtained. It was issued ex parte, without notice to [defendants] and without any effort, however informal, to invite or permit their participation in the proceedings. ... [T] here is no place within the area of basic freedoms guaranteed by the First Amendment for such orders where no showing is made that it is impossible to serve or to notify the opposing parties and to give them an opportunity to participate. ${ }^{326}$

If the Maryland judge cannot forbid those defendants' public meeting without notice, then, a fortiori, another judge cannot grant a plaintiff like Baldder an ex parte order suppressing a defendant like Lokki's internet activity. For, in the latter, the noise and traffic considerations in public meetings and street demonstrations are absent. Also, the ex parte order that the Minnesota judge granted against Jay Near would be an unconstitutional violation of proper First Amendment procedure today following Carroll.

The federal rule for a TRO anticipates that some TROs will follow attenuated adversary procedure. ${ }^{327}$ Federal procedure contemplates a second interlocutory order, the preliminary injunction. ${ }^{328}$ A judge will grant a plaintiff a preliminary injunction after notice to the defendant and an unspecified amount of adversary procedure. $^{329}$

323. See 28 U.S.C. $\S 1292(a)(1)$. But see CAL. Civ. Proc. CodE $\S$ 904.1(a)(1) (West 2018).

324. See FED. R. CIV. P. 65(b).

325. See, e.g., Carroll v. President \& Comm'rs of Princess Anne, 393 U.S. 175, 180

(1968). Ex parte temporary orders may be constitutional but are not wise and should not be granted. See Volokh, supra note 2 (manuscript at 44).

326. Carroll, 393 U.S. at 180.

327. See FED. R. CIV. P. 65(b).

328. See FeD. R. CIV. P. 65(a).

329. See RendLeman, supra note 146, at 333-41. 
In addition to notice, what procedure must a judge follow to grant a plaintiff an interlocutory injunction that affects the defendant's speech, which may or may not be protected expression? There are two techniques to reduce or eliminate error in interlocutory injunction procedure. First, there is the preliminary injunction standard, a test that includes a calculation of how likely the plaintiff's claim is to succeed on plenary hearing. ${ }^{330}$ Second, there is the injunction bond. ${ }^{331}$

May a judge grant a plaintiff an interlocutory injunction that forbids a defendant's defamation following adversary, but less than plenary, procedure? "No" answer two prominent scholars, Redish, a generation ago, and Ardia in 2013; these scholars disapprove of all interlocutory defamation injunctions. ${ }^{332}$

"Full adjudication" is required, wrote Ardia. ${ }^{333}$ Since the judge at this point in the litigation process has not conducted the plenary hearing, in this view, the decision on the merits is tentative. ${ }^{334}$ Under one formulation of the preliminary injunction standard, the judge must find that the plaintiff's ultimate success on the merits is likely. ${ }^{335}$ This is not sufficient for Ardia who insists that the judge should not forbid a defendant's expression after a finding of the plaintiff's "likelihood of success" on the merits. ${ }^{336}$ The California court in Balboa and a New Jersey court in Chambers v. Scutieri required a trial as a prerequisite for an anti-defamation injunction. ${ }^{337}$

I am unable to accede fully because, for me, waiting that long to enjoin favors the defendant more than necessary. A wily defendant can use pleading, discovery, and a motion for summary judgment to delay a plenary hearing for a year or more leaving the defendant's defamation hanging in the air. The judge, in my view, should require a defamation plaintiff seeking a

330. See id. at 333; see also FED. R. CIV. P. 65(c).

331. See id. at 333-34.

332. See Ardia, supra note 1, at 38-41; Redish, supra note 159, at 87-89; see also Salinger v. Colting, 607 F.3d 68, 82 (2d Cir. 2010) ("Every injunction issued before a final adjudication on the merits risks enjoining speech protected by the First Amendment."). But see Wells, supra note 141, at 64-66.

333. Ardia, supra note 1, at 38-41, 59 n.256.

334. See RENDLEMAN, supra note 146, at 334.

335. See id. at $333,339$.

336. Ardia, supra note 1, at 59; see also Bertelsman, supra note 157, at 337 (arguing that there is no reason not to issue an injunction after a plenary hearing).

337. Balboa Island Vill. Inn, Inc. v. Lemen, 156 P.3d 339, 343 (Cal. 2007); Chambers v. Scutieri, No. A-4831-10T1, 2013 WL 1337935, at*1 (N.J. Super. Ct. App. Div. Apr. 4, 2013). 
preliminary injunction either to show that success on the merits is $51 \%$ likely, or consolidate the preliminary injunction hearing with the merits. ${ }^{338}$

Other scholars would require some judicial finding before a judge could forbid a defendant's speech. ${ }^{339}$ Under a sliding-scale preliminary-injunction standard, the judge may grant a plaintiff a preliminary injunction after finding "sufficiently serious questions going to the merits to make them a fair ground for litigation and a balance of hardships tipping decidedly toward the" plaintiff. $^{340}$

Whether a judge should enjoin a defendant's expression after finding that the plaintiff showed a "fair ground of litigation" remains an open question. ${ }^{341}$ The Dublin High Court, following that standard, granted the plaintiff an interim injunction against the ISPs where the third parties' defamation was lodged. ${ }^{342}$ The judge, in my view, should not grant an anti-defamation preliminary injunction based on a less than $50 \%$ "fair ground of litigation." This position eliminates the second branch of the Second Circuit Court of Appeals' slidingscale preliminary injunction standard. ${ }^{343}$ A court should adopt a variablethreshold test that requires the plaintiff to demonstrate a strong probability of success on the merits for a preliminary injunction in a free speech case. ${ }^{344}$

Observers use imprecise language to describe appropriate prior restraint procedure because they are discussing executive and administrative systems as well as criminal and civil procedure. For the civil procedure we are discussing, the more balanced approach to a plaintiff's interlocutory relief against a defendant's defamation, and the one I favor, is Schauer's for obscenity. ${ }^{345}$ Schauer read Carroll v. President and Commissioners of Princess Anne with Freedman v. Maryland to disapprove ex parte procedure altogether and to require adversary procedure before restricting a defendant's expression

338. FeD. R. CIV. P. 65(a); see also Morton Denlow, The Motion for a Preliminary Injunction: Time for a Uniform Federal Standard, 22 REV. LiTIG. 495, 532 (2003) (arguing that courts should eschew a preliminary injunction for an early trial on the merits).

339. Wells, supra note 141, at 64-66. Volokh's article agrees on the central point of approving an anti-libel injunction if the court follows adequate procedure. See Volokh, supra note 2 (manuscript at 42-43).

340. Sonesta Int'l Hotels Corp. v. Wellington Assocs., 483 F.2d 247, 250 (2d Cir. 1973). The question of whether the sliding scale preliminary injunction standard survives the Supreme Court's decision in Winter v. Nat'l Res. Def. Council, 555 U.S. 7, 24, 51 (2008), seems to have been decided, at least at the Court of Appeals level, in favor of the sliding scale. See Salinger v. Colting, 607 F.3d 68, 76-80 (2d Cir. 2010); Cornwell v. Sachs, 99 F. Supp. 2d 695, 702, 714 (E.D. Va. 2000) (enjoining defamation preliminarily as false advertising); Jean C. Love, Teaching Preliminary Injunctions After Winter, 57 ST. LOUIS U. L.J. 689, 689 (2013).

341. Sonesta Int'l Hotels, 483 F.2d at 250.

342. McKeogh v. Doe [2012] IEHC 95 (H.Ct.) (Ir.).

343. Salinger, 607 F.3d at 76-80.

344. R. Grant Hammond, Interlocutory Injunctions: Time for a New Model?, $30 \mathrm{U}$. TORONTO L.J. 240, 278, 280 (1980).

345. SCHAUER, supra note $189, \S \S 12.1-.7$, at 228-46. 
with a temporary restraining order or preliminary injunction. ${ }^{346}$ Factual evidence should, if possible, be tested by cross-examination.

As examined below, in almost all states and the federal system, there will be no jury at the plenary trial for an injunction. ${ }^{347}$ An adversary bench hearing with cross-examination of factual evidence followed by a judicial finding of the defendant's fault and the plaintiff's likely success on the merits that the defendant's statement was defamatory and false should suffice. ${ }^{348}$

For a preliminary injunction ...., the court must hold an adversarial hearing that resembles, as closely as possible, a full trial, including adherence to evidentiary rules, live testimony in addition to documents and affidavits, and an opportunity for cross-examination.... [P]rocedural protections and aggressive appellate review ... must also be available, as well. ${ }^{349}$

Courts have recognized that withdrawing the injunction remedy for libel is primarily based on concern about incomplete interlocutory procedure that may not apply to injunctions granted after adversary procedure. ${ }^{350}$

Professor Leubsdorf asked, could a plaintiff "get a preliminary injunction against defamation without [the judge's] consideration of the merits, and would this amount to a prior restraint forbidden by the First Amendment?"351 This article answers Leubsdorf's first question: a judge should not grant a plaintiff a preliminary injunction without considering the merits. If the judge did, the order would fail as a procedural prior restraint.

A plaintiff who receives an interlocutory injunction will post an injunction bond. ${ }^{352}$ The bond requirement cautions a plaintiff against a hasty and illconsidered application for interlocutory relief. ${ }^{353}$ And if an interlocutory injunction turns out to be incorrect, the bond is available to compensate

346. Id. at $\S 12.1$, at 231, 232 n.21 (first citing Freedman v. Maryland, 380 U.S. 51 (1965); then citing Carroll v. President \& Comm'rs of Princess Anne, 393 U.S. 175 (1968); then citing Marcus v. Search Warrants, 367 U.S, 717 (1961); and then citing Tenney v. Liberty News Distribs., Inc., 215 N.Y.S.2d 663 (App. Div. 1961)).

347. See infra note 359 and accompanying text.

348. See Wells, supra note 141 , at 66.

349. Id. at 66 \& n.326; see Ardia, supra note 1, at 38-41, 59.

350. See, e.g., Alsworth v. Seybert, 323 P.3d 47, 56 (Alaska 2014); CapStack Nashville 3, LLC v. MACC Venture Partners, No. 2018-0552-SG, 2018 WL 3949274, *3-5 (Del. Ch. Aug. 16, 2018).

351. John Leubsdorf, Preliminary Injunctions: In Defense of the Merits, 76 FORDHAM L. REV. 33, 40 (2007) (first citing Vance v. Universal Amusement Co., 445 U.S. 308 (1980); and then citing Neb. Press Ass'n v. Stuart, 427 U.S. 539 (1976)).

352. FED. R. CIV. P. 65(c).

353. See RENDLEMAN \& RoBERTs, supra note 312 , at 480-82. 
the defendant for her losses while the incorrect interlocutory order circumscribed her conduct. ${ }^{354}$

The American litigation system does not have much experience with injunction bonds in defamation litigation. The judge, it seems to me, ought to set the bond after carefully evaluating the defendant's potential loss from an incorrect interlocutory injunction. A judge calculating a defendant's recovery of damages from a plaintiff's injunction bond should consider and evaluate that an incorrect order impinges on the defendant's First Amendment right to free expression.

An example: After a disappointed car buyer excoriated the automobile dealer on a website, he was preliminarily enjoined to stop. ${ }^{355}$ During the preliminary injunction period, the dealer's lawyer threatened to have the customer-defendant "jailed or fined for contempt." ${ }^{356}$ After finding that the preliminary injunction was improper and dissolving it, the judge, in addition to $\$ 766.45$ of out-of-pocket defense costs, awarded the car buyer $\$ 4,000$ for mental anguish and $\$ 2,000$ for loss of free speech rights from the dealer's injunction bond. ${ }^{357}$

\section{E. The Absence of a Jury}

An injunction is an equitable remedy that is not included under most constitutional guarantees of a jury trial. ${ }^{358}$ Except in the state courts of Texas and North Carolina, an injunction defendant is not entitled to a jury for either an interlocutory or a final injunction. ${ }^{359}$ The Supreme Court held in Alexander v. Virginia that a jury trial is not required for civil obscenity, a close relative of defamation. ${ }^{360}$ The plaintiffs in three of the defamation decisions this Article examines, Tory v. Cochran, Kinneyv. Barnes, and Balboa Island Village Inn, Inc. v. Lemen, forwent damages and sued for injunctions only. ${ }^{361}$

354. See FeD. R. Civ. P. 65(c); RendLEMAN, supra note 146, at 360-61, 365; see also Cornwell v. Sachs, 99 F. Supp. 2d 695, 714 (E.D. Va. 2000) (requiring a $\$ 50,000$ bond); RENDLEMAN \& ROBERTS, supra note 312, at 480-82.

355. Crown Pontiac, Inc. v. Ballock, 287 F. Supp. 2d 1256, 1256 (N.D. Ala. 2003).

356. Id. at $1256-57$.

357. Id. at $1258-59$

358. See, e.g., 1 Dan B. Dobbs, Dobbs Law of Remedies: Damages-EQuityRESTITUTION 70 (2d ed. 1993).

359. Eric J. Hamilton, Note, Federalism and the State Civil Jury Rights, 65 StAN. L. REV. 851, 857-58, 885-86 (2013).

360. 413 U.S. 836, 836 (1973) (per curiam).

361. Tory v. Cochran, 544 U.S. 734, 735-36 (2005); Balboa Island Vill. Inn, Inc. v. Lemen, 156 P.3d 339, 342 (Cal. 2007); Kinney v. Barnes, 443 S.W.3d 87, 90 (Tex. 2014); see also Chambers v. Scutieri, No. A-4831-10T1, 2013 WL 1337935, at*5 (N.J. Super. Ct. App. Div. Apr. 4, 2013) (adjudicating a case in which the plaintiff sued for injunction only, not damages). 
In Tory and Balboa, the California lawsuits, if the defamation plaintiff's demand for an injunction succeeds through pleading and discovery to plenary trial, neither the plaintiff nor the defendant would be entitled to a jury. ${ }^{362}$ The judge will find the facts. The absence of a jury at the plenary trial for an injunction is one reason not to disapprove an interlocutory antidefamation injunction that followed the adversary procedure discussed above. In Kinney, in the Texas state court, there would be a jury right. ${ }^{363}$

If a defamation plaintiff demands both damages and an injunction, as hypothetical plaintiff Baldder does, his demand for damages is one at common law that, with the exceptions above, brings a constitutional jury right in its train. ${ }^{364}$ In the federal system and many of the states, the jury will find the facts leading to the defendant's liability for damages and then, on the plaintiff's motion, the judge may grant or deny the plaintiff a final injunction that is consistent with the jury's findings of fact. ${ }^{365}$ The jury will determine whether the defendant said or wrote the statements that the plaintiff alleges to be defamatory, but the question of whether the First Amendment protects the defendant's expression is a question of law for the judge. ${ }^{366}$ The jury will play no role in that constitutional decision.

"Equitable cleanup" is another approach to the jury trial that may be available in some state systems. ${ }^{367}$ Once a plaintiff's case is properly filed for an equitable remedy, an injunction, the Equity judge will clean the case up by conducting a bench trial and also ruling on the plaintiff's demand for damages. ${ }^{368}$

Many First Amendment and defamation scholars disfavor the jury in free speech and defamation litigation because they think that jurors lack sensitivity to free speech values. ${ }^{369}$ In the words of libel-reformer Professor

362. See Tory, 544 U.S. at 736; Balboa Island Vill. Inn, 156 P.3d at 341-42.

363. See Ex parte Tucci, 859 S.W.2d 1, 2 n.4 (Tex. 1993); Hamilton, supra note 359, at $857-58,885-86$.

364. RENDLEMAN \& ROBERTS, supra note 312 , at 382-85.

365. See Beacon Theatres, Inc., v. Westover, 359 U.S. 500, 501-11 (1959); Chambers, 2013 WL 1337935, at *8 (finding that no jury trial is required for an injunction against defendant's defamation); Hamilton, supra note 359, at 869 fig.1.

366. See Redish, supra note 159, at 64-65.

367. Hamilton, supra note 359, at 864, 890-91, 895-96.

368. Leman v. Krentler-Arnold Hinge Last Co., 284 U.S. 448, 456-57 (1932); Hamilton, supra note 359 , at $856,864,869$ fig. 1 .

369. See Anderson, Reforming, supra note 81, at 540-41; Jeffries, supra note 162, at 428 n.60 (quoting Henry P. Monaghan, First Amendment "Due Process," 83 Harv. L. REV. 518, 528-29 (1970)); see also Monaghan, supra, at 527. But see CHAFEE, supra note 182, at 503; Ardia, supra note 1, at 63-65; Redish, supra note 159, at 65-66. 
Halpren, "exposure to the vicissitudes of capricious juries" leads to "inflated demands and verdicts" and "apparently open-ended and unstructured awards of presumed damages [that] are at the center of the antipathy toward the jury." 370

However, Ardia and Professor Siegel disapprove of the judge granting an injunction before a jury finds the elements of defamation. ${ }^{371}$ Their requirement of full adjudication and a jury finding of defamation is consistent with their disapproval of an interlocutory injunction that forbids defamation. ${ }^{372}$ However, the professors' prerequisite of a jury finding of defamation changes the traditional jury doctrines and departs from the typical practice that the judge may grant an injunction. ${ }^{373}$

The First Amendment is a non-majoritarian protection for minority rights. ${ }^{374}$ It shields people who expresses unpopular ideas from a majority's decision to suppress their expression. ${ }^{375}$ "A common passion or interest," James Madison wrote in Federalist 10, "[will] be felt by a majority[,] . . and there is nothing to check the inducements to sacrifice the weaker party." ${ }^{376}$ A jury that represents the community consensus may implement the majority's impulse to suppress speech instead of protecting a weird or eccentric defendant with splinter views. In addition, a judge who should be better versed in First Amendment lore will also be subject to appellate review. Plaintiffs Cochran, Kinney, and the Balboa Island Village Inn spurned damages and sued their defendants for an injunction only. ${ }^{377}$ In addition to probably not expecting to collect damages judgments from their defendants, they may have known something about the jury in free speech and defamation adjudication. ${ }^{378}$

370. Halpern, supra note 249, at 232, 240, 243.

371. Ardia, supra note 1, at 39-41, 64 \& n.278 (citing RANDOLPH N. JONAKAIT, THE AMERICAN JURY SYSTEM 27 (2003)); Stephen A. Siegel, Injunctions for Defamation, Juries, and the Clarifying Lens of 1868, 56 BUfF. L. REv. 655, 726-35 (2008). Judge Becker, who favored an injunction after a jury decision against the defendant, was constrained by Pennsylvania precedent that forbids an injunction against defamation. See Kramer v. Thompson, 947 F.2d 666, 678-79 (3d Cir. 1991).

372. Ardia, supra note 1, at 38-41.

373. See Chambers v. Scutieri, No. A-4831-10T1, 2013 WL 1337935, at *7-8 (N.J. Super. Ct. App. Div. Apr. 4, 2013) (finding that no jury trial is required for an injunction against defendant's defamation); Ardia, supra note 1, at 63-65.

374. See Terrence Sandalow, Judicial Protection of Minorities, 75 Mich. L. REv. 1162, 1164 (1977).

375. Id.

376. The Federalist No. 10, at 70 (James Madison) (Floating Press 2011) (1787).

377. Tory v. Cochran, 544 U.S. 734, 736 (2005); Kinney v. Barnes, 443 S.W.3d 87, 87 (Tex. 2014); Balboa Island Vill. Inn, Inc. v. Lemen, 156 P.3d 339, 342 (Cal. 2007).

378. If a plaintiff sues for defamation and demands an injunction, but not damages, the judge may decline an injunction and award him damages instead under Fed. R. Civ. P. 54(c). 
In addition, requiring plenary jury procedure seems to me to underprotect a defamation plaintiff. If, as in Baldder v. Lokki, someone is using a gripe-site to excoriate a home-improvement contractor falsely as a thief, that contractor's business will decline or disappear almost immediately. Because delay favors the defendant, a defendant's skillful lawyer may be able to protract pleading, discovery, and summary judgment for a year or more while the plaintiff's business dries up. ${ }^{379}$

A jury finding of defamation should not be a prerequisite for an injunction. A plaintiff like Johnnie Cochran or the Balboa Island Village Inn should be able to spurn the gold and sue a defendant for only an injunction. If a plaintiff sues a defendant for both damages and an injunction, a judge should be able, after the adversary procedure discussed above, to grant him an interlocutory injunction. If one litigant demands a jury, the judge should be able to grant an appropriate final injunction following a jury trial and a plaintiff's verdict.

Before taking up an injunction, we will detour slightly to consider a defamation plaintiff's alternatives, non-monetary remedies short of an injunction.

\section{AlternAtive REMEDIAL APPROACHES}

Below this Article examines a plaintiff's remedies for the defendant's defamation: a declaratory judgment, nominal damages, a special verdict, an apology, a retraction, and a private settlement. Restitution, monetary relief based on defendant's benefit, instead of plaintiff's loss, has not generated much interest in defamation. Professor Dobbs speculated that may be because libel plaintiffs "are much better off with the vague general or presumed damages and the unmeasurable emotional distress damages." 380

\section{A. Declaratory Judgment}

Does the plaintiff really need an injunction? A declaratory judgment is a litigated judicial order that defines the parties' rights under the applicable

379. See Nat'l Ctr. for State Courts, Civil Justice Initiative: The LandSCAPE of Civil Litigation in State CourTs, at v (2013).

380. 2 DoBBS, supra note $358, \S 7.2$, at 297. 
law. ${ }^{381}$ Some maintain that a declaratory judgment will suffice instead of an injunction. ${ }^{382}$

A declaratory judgment does resemble an injunction in the sense that defendants usually obey both. ${ }^{383}$ An important difference, however, between an injunction and a declaratory judgment is that the judge may enforce an injunction, but not a declaratory judgment, with contempt. ${ }^{384}$

A declaratory judgment may be a foundation for an injunction. ${ }^{385}$ For a mixed example, an inventor who wonders whether her idea might, if commercially developed, induce a patent owner to sue her for infringement may seek a declaratory judgment that the patent-owner defendant's patent is invalid and that her proposed product does not infringe any of the defendant's valid patents. ${ }^{386}$ Based on a declaration, the inventor might, or might not, move for an injunction that forbids the defendant from suing her on its patent. Sometimes a declaration suffices. A judge applying equitable discretion could make a contextual decision that a declaratory judgment will fit the plaintiff's needs because the contempt sanction is not needed for a particular defamation defendant. ${ }^{387}$

The Court in Sullivan held that the Constitution limits state authority to award damages for libel. ${ }^{388}$ Libel-reform scholars asserted that declaratory judgments would protect the press from pesky plaintiffs' libel actions. ${ }^{389}$ They argued that few libel plaintiffs recover anything, since most of their lawsuits fail because the defendants lack Sullivan malice. ${ }^{390}$ Their research showed that most libel plaintiffs really only wanted to clear the public record and restore their impaired reputations. ${ }^{391}$ Libel-reformers' proposals eliminated money damages in favor of a terminal declaratory judgment of falsity that is not a foundation for damages. ${ }^{392}$

381. Doug Rendleman, Prospective Remedies in Constitutional Adjudication, $78 \mathrm{~W}$. VA. L. REV. 155, 167 (1976).

382. See Samuel L. Bray, The Myth of the Mild Declaratory Judgment, 63 DuKE L.J.

1091, 1109, 1113 (2014).

383. See id. at 1112

384. See id. at 1093-94, 1102-04.

385. See id. at $1111 \&$ n.102 (first quoting 28 U.S.C. $\$ 2202$ (2012); and then citing

Unif. DeClaratory Judgments ACTS $\S 8$ (1922), 12A U.L.A. 528 (2011)).

386. See id. at $1105,1111 \&$ n.102 (first quoting 28 U.S.C. $\S 2202$; and then citing

UNIF. DECLARATORY JudgmeNTS ACTS $\S 8$ (1922), 12A U.L.A. 528 (2011)).

387. See id. at 1110.

388. N.Y. Times Co. v. Sullivan, 376 U.S. 254, 283 (1964).

389. See Randall P. Bezanson, Gilbert Cranberg \& John Soloski, Libel Law AND THE PRESS: MYTH AND REALITY 224 (1987).

390. See id. at 180.

391. Id. at $177,213$.

392. Id. at $211,224$. 
In Gertz v. Robert Welch, Inc., Justice Brennan advocated declaratory judgment statutes to lead to declarations of falsity. ${ }^{393}$ Judge Pierre Leval suggested a libel action for a declaratory judgment of falsity without examining Sullivan malice and without awarding damages. ${ }^{394}$ Professor Bezanson developed the idea that if no money damages were awarded, then there should be no Sullivan privilege bars for a plaintiff's declaratory judgment of falsity against a defendant's libel. ${ }^{395}$

Representative Charles Schumer introduced a bill in Congress that provided for a no-fault, no-damages declaratory judgment of falsity-defamation, which included the defendant's option to convert a plaintiff's damages action into a no-damages declaratory judgment. ${ }^{396}$ Potential defendants in mediadominated or media-influenced bodies developed legislative defamationreform statutory proposals. ${ }^{397}$

The Annenberg Washington Program's Libel Reform Project proposed a comprehensive proposal similar to Schumer's bill. ${ }^{398}$ First, the alleged libel victim must demand a retraction. ${ }^{399}$ The potential defendant's retraction or opportunity to reply precludes the victim's suit. ${ }^{400}$ Second, if the victim does file a libel suit, either the plaintiff or the defendant can convert it into a no-fault no-damages declaratory judgment action of falsity or not. ${ }^{401}$ The judge would try the declaratory judgment promptly. No money damages would be permitted except attorney fees. ${ }^{402}$ Third, if neither party chooses a declaratory judgment, which seems unlikely, the prevailing plaintiff's damages recovery is limited to pecuniary loss, harm to reputation and personal

393. 418 U.S. 323, 365-66 (1974).

394. Pierre N. Leval, Commentary, The No-Money, No-Fault Libel Suit: Keeping Sullivan in Its Proper Place, 101 HARV. L. REV. 1287, 1288 (1988); see also Michael Kent Curtis, Monkey Trials: Science, Defamation, and the Suppression of Dissent, 4 WM. \& MARY BILL RTS. J. 507, 562 \& n.314 (1995) (arguing to eliminate damages, try truth versus falsity, and for the loser to pay the winner's attorney fee).

395. See BeZANSON, Cranberg \& Soloski, supra note 389, at 221-24.

396. H.R. 2846, 99th Cong. (1985), 131 CONG. REC. 16,942 (1985).

397. See NAT'L CONFERENCE OF COMM'RS ON UNIF. STATE LAWS, UNiform Correction or Clarification of Defamation Act 1 (1993); SMOlla ET Al., supra note 252, at 7.

398. Rodney A. Smolla \& Michael J. Gaertner, The Annenberg Libel Reform Proposal: The Case for Enactment, 31 WM. \& MARY L. REV. 25, 32-34 (1989).

399. Id. at 32.

400. Id. at 33 .

401. Id.

402. See BeZANSON, CranBerg \& Soloski, supra note 389, at 211. 
suffering and anguish, and excludes recovery of both presumed general damages and punitive damages. ${ }^{403}$

First Amendment protected free speech is not free. Sheltering someone's injurious and tortious speech has harmful consequences to third persons, harm that is neither borne equally nor distributed fairly. ${ }^{404}$ Recognition of the argument that "many libel plaintiffs $d o$ want money" and that, for a plaintiff's actual damages, "money provides vital compensation" has militated against converting the traditional defamation tort into a no-fault, no-damages declaratory judgment system in the interest of warming the "chilling effects" of successful defamation lawsuits against media defendants. ${ }^{405}$ "[F]rom the defendant's point of view, a declaration of falsity would not mean very much." 406

As an exclusive remedy, the symbolic victory of a declaratory judgment falls short of the compensatory and deterrence goals the tort system seeks in the libel tort. The libel-reformers' legislative proposals "fizzled out."407

403. Smolla \& Gaertner, supra note 398, at 32; see SMOLLA ET AL., supra note 252, at 12; see also NAT'L CONFERENCE OF COMM'RS ON UNIF. STATE LAWS, supra note 397, at 3. North Dakota adopted the Uniform Act. Uniform Correction or Clarification of Defamation Act, N.D. CenT. Code ANN. § 32-43-01 to -10 (West 2010). The Commission on Obscenity and Pornography recommended greater use of civil declaratory procedures to avoid the effect of subsequent criminal punishment on future speech. See COMM'N ON OBSCENITY \& PORNOGRAPHy, The REPORT OF THE COMMISSION ON OBSCENITY AND PORNOGRAPHY 63 (1970). The Commission's report states that:

A declaratory judgement procedure ... would permit prosecutors to proceed civilly, rather than through the criminal process, against suspected violations of obscenity prohibition. If such civil procedures are utilized, penalties would be imposed for violation of the law only with respect to conduct occurring after a civil declaration is obtained. The Commission believes this course of action to be appropriate whenever there is any existing doubt regarding the legal status of materials; where other alternatives are available, the criminal process should not ordinarily be invoked against persons who might have reasonably believed, in good faith, that the books or films they distributed were entitled to constitutional protection, for the threat of criminal sanctions might otherwise deter the free Id. distribution of constitutionally protected material.

404. See, e.g., Frederick Schauer, Harm(s) and the First Amendment, 2011 SuP. CT. REV. 81, 88-90 (2012). Professor Schauer gives the example of the tortious speech in Snyder v. Phelps, 562 U.S. 443 (2011), that the Supreme Court exonerated from damages liability. See David S. Han, Rethinking Speech-Tort Remedies, 2014 WIS. L. REV. 1135, $1137-38$.

405. C. Thomas Dienes, Libel Reform: An Appraisal, 23 U. Mich. J.L. REFORM 1, 15-17 (1989) (citing BEZANSON, CRANBERG \& SOlOSKI, supra note 389, at 93); see 3 DOBBS, HAYDEN \& BuBLICK, supra note 7, § 577, at 347-48; see also Donald L. Magnetti, "In the End, Truth Will Out," . . Or Will It?, 52 Mo. L. REv. 299, 349-51 (1987) (stating that the Schumer bill is "not a viable solution").

406. Halpern, supra note 249, at 237. But see Anderson, Reforming, supra note 81, at $545,548$.

407. Han, supra note 404, at 1140, 1154-56. 
Professor Han published a proposal in 2014 in the Wisconsin Law Review. ${ }^{408}$ Han maintains that either legislatures or courts ought to remake the law by dropping as blunt and rigid the all-or-nothing binary approach to a plaintiff's recovery of defamation damages and replacing it with a flexible, nuanced, and complex approach that balances and adjusts plaintiff's damages by considering free speech principles and tort principles. ${ }^{409}$ With the respect due to his thoughtful and thoroughly researched proposal, it is dead on arrival.

The declaratory judgment as an alternative or foundation remedy is potentially useful. Many websites will remove material following a declaratory judgment that it is defamatory. ${ }^{410}$ Moreover, some libel plaintiffs might prefer the reputation-restoring value of a declaratory judgment of falsity or a public retraction over losing a damages action outright because they had failed to prove Sullivan malice.

\section{B. Nominal Damages and Special Verdicts}

The litigation system provides possible solutions that are variations on the declaratory judgment.

First, a plaintiff's verdict and a recovery of nominal damages may resemble a declaratory judgment because it labels the defendant's publication as false and vindicates the plaintiff. ${ }^{411}$ Professor LeBel wondered, however, whether nominal-damages litigation was an efficient way to use the court system. ${ }^{412}$

Second, in Ariel Sharon's libel suit against Time Magazine ${ }^{413}$ the trial judge instructed the jury to return special verdicts on the separate questions of falsity, libel, and Sullivan malice. ${ }^{414}$ The jury found that the magazine's statements were false and defamatory, but it insulated the magazine from liability to Sharon for damages because Time's Sullivan malice was lacking. ${ }^{415}$

408. Id. at $1135-99$.

409. See id. at 1192-94.

410. See Aaron Morris, How to Stop Defamation When You Can't Afford an Attorney, InTERNET DeFAMATION BlOG (July 5, 2016), http://internetdefamationblog.com/how-tostop-defamation-when-you-cant-afford-an-attorney/\#more-11 [https://perma.cc/Y325-JMSL].

411. Afro-American Publ'g Co. v. Jaffe, 366 F.2d 649, 660 (D.C. Cir. 1966); Grossman v. Goemans, 631 F. Supp. 972,974 (D.D.C. 1986) (quoting Arilie Foundation, Inc. v. Evening Star Newspaper Co., 337 F. Supp. 421, 431 (D.D.C. 1972)) (awarding \$2500 nominal damages for defamation); see Robertson v. McCloskey, 680 F. Supp. 414, 416 (D.D.C. 1988).

412. See Paul A. LeBel, The Infliction of Harm Through the Publication of Fiction: Fashioning a Theory of Liability, 51 BROOK. L. REV. 281, 318 \& n.149 (1985).

413. Sharon v. Time, Inc., 575 F. Supp. 1162 (S.D.N.Y. 1983).

414. See Magnetti, supra note 405, at 360-61.

415. Id. at 361 . 
The litigants' reactions were, to say the least, mixed. Plaintiff Sharon felt that the widely publicized verdict of falsity meant that he was vindicated because he won a moral victory. ${ }^{416}$ However, Time issued a statement that Sharon's suit never should have been in court and that "Time has won it."

Exonerating an intentional or malicious tortfeasor is a serious step. The Comment in the Second Restatement of Torts, suggests that a damage judgment for compensatory or punitive damage may vindicate the injured party better than a simple determination of legal rights leading to nominal damages. ${ }^{418}$

\section{Retraction, Reply, Apology, Settlement}

In addition to a declaratory judgment, other possible personal orders that might be defamation remedies include retraction, reply, and apology. In Kinney v. Barnes, Kinney asked for an apology and a retraction but dropped those remedies in the trial court. ${ }^{419}$ States have voluntary retraction statutes that allow a libel defendant to mitigate a plaintiff's damages, usually punitive damages. ${ }^{420}$ A reply statute is another possibility. ${ }^{421}$ However, a court-ordered retraction or reply through an injunction ordering the defendant to recant or to print the plaintiff's reply is forced speech that may violate the First Amendment. ${ }^{422}$ In any event, there is reason to doubt that a defendant's retraction effectively undoes the plaintiff's damage or restores his reputation. ${ }^{423}$ "We are not persuaded, however," wrote the Iowa court about internet defamation, "that the Internet's ability to restore reputations matches its ability to destroy them."

The apology as part of a personal order, an injunction or coercive contempt, has generated scholarly interest. Some is positive. ${ }^{425}$ But some is negative;

\footnotetext{
416. See id.

417. Id. (quoting Statement from Time Inc., N.Y. TIMES, Jan. 25, 1985, at B4, col. 1).

418. RESTATEMENT (SECOND) OF TORTS $\S 90 \mathrm{cmt}$ c c (AM. LAW. INST. 1979).

419. Kinney v. Barnes, 443 S.W.3d 87, 90 (Tex. 2014).

420. Anderson, Reforming, supra note 81, at 547.

421. See generally 3 DOBBS, HAYDEN \& BUBLICK, supra note 7, § 576, at 346-47; Magnetti, supra note 405, at 346-49.

422. See, e.g., Miami-Herald Publ'g Co. v. Tornillo, 418 U.S. 241, 258 (1974); Kramer v. Thompson, 947 F.2d 666, 682 (3d Cir. 1991) (no forced retraction); William W. Van Alstyne, The Möbius Strip of the First Amendment: Perspectives on Red Lion, 29 S.C. L. REV. 539, 543-44 (1978).

423. See Halpern, supra note 249, at 241.

424. Bierman v. Weier, 826 N.W.2d 436, 454 (Iowa 2013).

425. See, e.g., John G. Fleming, Retraction and Reply: Alternative Remedies for Defamation, 12 U.B.C. L. REV. 15, 30-31 (1978); Walter V. Schaefer, Defamation and the First Amendment: The Coen Lecture, 52 U. COLO. L. REV. 1, 16-18 (1980); Daniel W. Shuman, The Psychology of Compensation in Tort Law, 43 U. KAN. L. REV. 39, 69-71
} 
an apology, which the defendant may fake, is not a substitute for adequate compensation. ${ }^{426}$ In an empirical experimental study, judges were "largely unmoved by apologies. ${ }^{9427}$ My views coincide with the skeptics. A defendant's apology, pressured by the leverage of an injunction or coercive contempt, is forced and lacks a ring of genuineness and sincerity. ${ }^{428}$ An observer may take a defendant's voluntary apology under the shadow of probable liability with a grain of salt.

Many potential defamation plaintiffs ask their potential defendants for correction, retraction, or an apology. ${ }^{429}$ Of course, because of a defendant's personal or professional ethics or as a part of a private settlement, a libel defendant can correct or retract an error, even apologize. Many newspapers regularly correct factual errors. To settle a lawsuit, a libel defendant can agree, as the National Enquirer did, to publish a retraction written by the victim's lawyer and to establish an annual prize. ${ }^{430}$

If a declaratory judgment will not always suffice and if retraction, reply, and apology are not apposite, then what kind of personal order will be appropriate? "The present law of libel is a failure," Anderson insisted. ${ }^{431}$ "It denies most defamation victims any remedy, and at the same time chills speech by encouraging high litigation costs and occasional large judgments. The route to reform is obvious: provide a remedy that will simplify litigation and reduce the threat of windfall verdicts." 432 Anderson examines several reform proposals, but he does not mention the injunction. ${ }^{43}$ The defamation reformers jumped from damages to the declaratory judgment, leapfrogging

(1994) (arguing that although "plaintiffs may prefer money to an apology," apologies should be complete defenses to dignitary torts).

426. Lee Taft, On Bended Knee (with Fingers Crossed), 55 DePaul L. Rev. 601, 610-11 (2006).

427. Jeffrey J. Rachlinski, Chris Guthrie \& Andrew J. Wistrich, Contrition in the Courtroom: Do Apologies Affect Adjudication?, 98 CoRNELl L. REV. 1189, 1214-16, 1215 tbl.3 (2013).

428. RENDLEMAN, supra note 146, at 735-37.

429. See, e.g., Roth v. Greensboro News Co., 6 S.E.2d 882, 885 (N.C. 1940).

430. Jim Dwyer, Lies About Hoffman Yield Prize for Playwrights, N.Y. TIMES, Feb. 26,2014 , at A1.

431. Anderson, Reforming, supra note 81, at 550.

432. Id. "If libel law is to be worth saving, it must provide not merely nominal remedies, but remedies that protect reputation effectively, at the least possible cost to speech." Id. at 492.

433. See generally id. at 537-50 (focusing instead on reconsidering constitutional law, litigation costs, and general politics of reform). 
over this Article's subject, an injunction. ${ }^{434}$ We turn next to an injunction to prevent the defendant's future defamation.

\section{THE ANTI-DEFAMATION INJUNCTION}

Granting an injunction that forbids the defendant's defamation will hinge upon the judge's consideration of the public-private distinction, drafting an anti-defamation injunction, enforcing it, and administering it through motions to modify-dissolve, contempt, finding a violation, and application of the collateral bar rule.

\section{A. Public-Private}

The judge's decision to grant the plaintiff an injunction that forbids the defendant's defamation includes two public interest-private interest issues. The Sullivan decision contributed important principles to free speech generally. The Court emphasized that the First Amendment's central meaning is a citizen's right to discuss public issues, in particular to criticize a public official. ${ }^{435}$ While Sullivan's overarching principle shaped free speech generally, the Court needed at least a quarter of a century of constitutional common law development to implement its principle. ${ }^{436}$ The Supreme Court has tried to impose the First Amendment constitutional principles that protect speech onto the state law of defamation's that protects reputation. ${ }^{437}$ The Court has developed dividing lines with the phrases "public" "official," "figure," "private," and "interest." 438 The public-private distinction serves an important purpose, but it is not satisfactory. In borderline cases, and some that are not really borderline, courts' results are unpredictable and random; the characterization often appears to be driven by results. ${ }^{439}$ The Court has created an unsatisfactory body of rules that are unstable, complex, frustrating, and ambiguous. ${ }^{440}$

434. See, e.g., Han, supra note 404, 1139 n.15.

435. See N.Y. Times Co. v. Sullivan, 376 U.S. 254, 264 (1964).

436. See, e.g., David A. Anderson, Wechsler's Triumph, 66 ALA. L. REV. 229, 252 (2014) [hereinafter Anderson, Triumph].

437. George C. Christie, The Uneasy and Often Unhelpful Interaction of Tort Law and Constitutional Law in First Amendment Litigation, 98 MARQ. L. REV. 1003, 1010-11 (2015).

438. See, e.g., Snyder v. Phelps, 562 U.S. 443, 463, 470 (2011) (Alito, J., dissenting).

439. See, e.g., Anderson, Promises, supra note 87, at 17-18; Volokh, supra note 2 (manuscript at 37-40).

440. See Sack, supra note 85, at 291; see also Anderson, Promises, supra note 87, at 16, 23; Anderson, Triumph, supra note 436, at 240-41. See generally Christie, supra, note 437 (arguing that tort and constitutional principles are not well integrated). 
Ardia raises the first public-private issue. He maintains that, to qualify for an injunction, the defendant's defamation must involve private, but not public, issues. ${ }^{441}$ In other words, the judge may not enjoin a defendant's defamation that relates to a public issue. ${ }^{442}$

In my opinion, tort law, including defamation, is public law, perhaps public law in disguise. ${ }^{443}$ Requiring the defendant's private defamation as a prerequisite for an injunction would complicate the issues and unnecessarily reduce the number of liability decisions that qualify for an injunction. As an observer who favors an injunction against the defendant's proved defamation, I do not agree to limit the remedy to private defamation.

Nor, I think, does the Supreme Court. In 2011, in Snyder v. Phelps, the Court exonerated members of the Westboro Baptist Church from a tort damages judgment on free speech grounds. ${ }^{444}$ The majority opinion observed that:

While these messages ["America is Doomed," "Semper Fi Fags," "Thank God for Dead Soldiers," "You're Going to Hell," "Priests Rape Boys," etc.] may fall short of refined social or political commentary, the issues they highlight - the political and moral conduct of the United States and its citizens, the fate of our Nation, homosexuality in the military, and scandals involving the Catholic clergy-are matters of public import. ${ }^{445}$

Both Jay Near's newspaper and Anna Lemen's protest activity raised publicpolicy issues, in particular the way the local authorities were administering the prohibition and alcohol-control laws. ${ }^{446}$ In addition to liquor with attendant issues of obedience to the law, both raised issues of business regulation, consumer protection, and public morality. ${ }^{447}$ The Near Court emphasized the public features of the plaintiffs' side of the public nuisance litigation. ${ }^{448}$ By today's standards, the Court's public policy reasoning was backwards;

441. Ardia, supra note 1, at 68.

442. Id. at 68 \& n.308 (quoting Siegel, supra note 371, at 736 n.434); see also Bertelsman, supra note 157, at 337-39; Gold, supra note 300, at 253-58.

443. See Doug Rendleman, Remedies: A Guide for the Perplexed, 57 ST. LouIs U. L.J. 567, 573-74 (2013).

444. Snyder v. Phelps, 562 U.S. 443, 443 (2011).

445. Id. at 454 .

446. See Near v. Minnesota ex rel. Olson, 283 U.S. 697, 704 (1931); Balboa Island Vill. Inn, Inc. v. Lemen, 156 P.3d 339, 342 (Cal. 2007).

447. See Near, 283 U.S. at 704 (involving gang activity, gambling, bootlegging, racketeering, and law enforcement's failure to perform their duties); Balboa Island Vill., 156 P.3d at 342 (involving child pornography, prostitution, drug sales, alcohol sales to minors, and business operating hours).

448. Near, 283 U.S. at 721-22. 
we think that public policy supports the person who criticizes the government rather than the targets of his criticism. By the Court's standard in Snyder, Jay Near's and Anna Lemen's intemperate statements were "matters of public import" despite their anti-Semitism and gay-bashing. ${ }^{449}$ Lokki's defamation of Baldder may be characterized as public in the sense that her issue is consumer protection although her factual charge is incorrect.

Requiring a private interest as a prerequisite for an injunction is a rope of sand, a guidepost on the road to nowhere. Public versus private is not a workable or useful distinction. It is unstable, indeterminate, meaningless, and subject to manipulation. For example, a farmer's billboard accused Reynolds Metals' alumina plant of polluting the air with fluorides. ${ }^{450}$ Preliminary injunction granted, said the judge, no legitimate public concern. ${ }^{451}$ The judge's view that air pollution is not a public issue is incredible today.

Internet decisions in state courts continue the inconsistency and confusion. A sex tape is in the public interest. ${ }^{452}$ An assertion of sexual abuse and failure of justice is, however, a matter of private concern. ${ }^{453}$ Nor is a charge of child molestation a matter of public concern. ${ }^{454}$ The best that can be said is that there is a large grey area between public and private and that courts' decisions and explanations are result-oriented and contextual. ${ }^{455}$

The law needs a principle of confinement to prevent judges from granting injunctions against speech that is directly related to the political and social policy process. It took twenty-five years to work out the uncertain borders around Sullivan's limitations of damages. ${ }^{456}$ If courts approve a limited injunction remedy in private libel, it may take a while for courts to fence it in. If public-private is too subjective, a specific point in the process like barring an injunction when the defendant's expression is election-related may serve to curtail this problem.

Second, a public-figure plaintiff suing to recover damages for the defendant's defamation must prove New York Times Co. v. Sullivan "actual malice." ${ }^{457}$ As Judge Sack has observed, "actual malice" is a term of First

\footnotetext{
449. See Snyder, 562 U.S. at 454.

450. Martin v. Reynolds Metals Co., 224 F. Supp. 978, 979 (D. Or. 1963).

451. Id. at 985 .

452. Gawker Media, LLC v. Bollea, 129 So. 3d 1196, 1201 (Fla. Dist. Ct. App. 2014).

453. W.J.A. v. D.A., 43 A.3d 1148, 1158 (N.J. 2012).

454. Bierman v. Weier, 826 N.W.2d 436, 436 (Iowa 2013).

455. See, e.g., Margaret Tarkington, The Truth Be Damned: The First Amendment, Attorney Speech, and Judicial Reputation, 97 GEO. L.J. 1567, 1629 n.365, 1631-33 (2009) (discussing the explanations courts give when refusing to apply Sullivan to defamation of the judiciary)

456. See, e.g., Anderson, Triumph, supra note 436, at 252.

457. N.Y. Times Co. v. Sullivan, 376 U.S. 254, 279-80 (1964). A defamation plaintiff who is not a public figure may recover damages for the defendant's negligent defamation. See 3 DOBBS, HAYDEN \& BUBLICK, supra note 7, § 564, at 301.
} 
Amendment art that does not have the common meaning of either "actual" or "malice." 458

Must a public-figure defamation plaintiff prove Sullivan malice as a prerequisite for an injunction? The California court in Balboa did not decide that issue. Instead, in a footnote, it observed that the lawsuit did not involve a public figure. ${ }^{459}$ Dean Chemerinsky assumed that a public-figure injunction plaintiff like the late Johnnie Cochran, would be required to prove Sullivan malice. ${ }^{460}$ The issue the Supreme Court granted cert to consider in Tory v. Cochran involved Johnnie Cochran as a public figure. ${ }^{461}$ Although Cochran's death after oral argument obscured the public-figure issue, the majority's decision that the injunction was too broad did not meet the public-figure issue. ${ }^{462}$ Justice Thomas's dissent reprobated the majority for straining to reach the over-breadth issue. ${ }^{463}$

Making a contrasting point about a declaratory judgment, like an injunction a non-monetary remedy, Professor Bezanson argued that if a declaratory judgment defendant had no risk of money damages, then the defendant should not be entitled to invoke the Sullivan privilege rules to bar a plaintiff's declaratory judgment against the defendant's libel. ${ }^{464}$ The plaintiff would not need to prove the defendant's actual malice to secure a declaratory judgment that he or she had been defamed. ${ }^{465}$

A damages verdict awards the plaintiff money damages, perhaps a large amount. It affects the defendant's pocketbook, not directly the defendant's future conduct. An injunction, on the other hand, forbids the defendant from continuing or repeating the defamation. ${ }^{466}$ An injunction affects the defendant's conduct in the future by ordering the defendant not to violate the plaintiff's legal rights. ${ }^{467}$ If the defendant obeys an anti-defamation injunction, the defendant's pocketbook will not be nicked. ${ }^{468}$

458. Sack, supra note 85, at 283-84 (quoting Reliance Ins. Co. v. Barron's, 442 F. Supp. 1341, 1349-1350 (S.D.N.Y. 1977); see also Anderson, Triumph, supra note 436, at $240-42$.

459. Balboa Island Vill. Inn, Inc. v. Lemen, 156 P.3d 339, 343 n.1 (Cal. 2007).

460. Chemerinsky, supra note 287, at 165-66.

461. Tory v. Cochran, 544 U.S. 734, 736 (2005).

462. Id. at 737.

463. See id. at 739-40.

464. See BeZANSON, CranBerg \& Soloski, supra note 389, at 222.

465. See id. at 220-25.

466. See Balboa Island Vill. Inn, Inc. v. Lemen, 156 P.3d 339, 350 (Cal. 2007).

467. Id.

468. Obeying a takedown injunction may not be completely costless. 
Do the damages and injunction remedies differ enough to warrant applying the Sullivan privileges in a plaintiff's action for damages but not in one for an injunction? So long as the plaintiff has established the defendant's defamation, which lacks First Amendment protection, I think so.

\section{B. Drafting an Injunction}

If the judge decides to grant a defamation plaintiff an injunction, the next task is to draft it.

A properly drafted injunction is the antidote to the fatal First Amendment flaws of vagueness and overbreadth.

When the language of a regulation [or injunction] is vague, speakers are left to guess as to the contours of its proscriptions. They are left without "fair notice" of the regulation's [or injunction's] reach. Commonly, this uncertainty will lead them to "steer far wider of the unlawful zone than if the boundaries of the forbidden areas were clearly marked."469

"A clear and precise enactment [or injunction] may nevertheless be 'overbroad' if in its reach it prohibits constitutionally protected conduct." 470

An injunction may govern a defendant's conduct that the civil law does not. One example is a buffer zone injunction around an abortion clinic that forbids defendants' picketing on the public sidewalk or street leading to the clinic. ${ }^{471}$ In the absence of the injunction, the defendants' picketing would be protected free expression. ${ }^{472}$ Other injunctions forbid defendants' ancillary and preparatory conduct that, except for the injunction, would not be a crime or a tort. ${ }^{473}$

Staying with Baldder v. Lokki, below are four examples of possible expression-related injunctions for a defendant's improper expression in defamation. ${ }^{474}$

Lokki has called Baldder a thief on GripeLex, a consumer-grievance website. The judge finds that thief is false and defamatory. Baldder moves for an injunction with two parts: first, to forbid Lokki from repeating the libel and, second, to order her to remove it from GripeLex. We will examine both parts of the injunction, although the part of the injunction that requires

469. Sypniewski v. Warren Hills Reg'l Bd. of Educ., 307 F.3d 243, 266 (3d Cir. 2002) (quoting Baggett v. Bullitt, 377 U.S. 360, 372 (1964)).

470. Grayned v. City of Rockford, 408 U.S. 104, 114 (1972).

471. Madsen v. Women's Health Ctr., 512 U.S. 753, 753 (1994).

472. See id. at 762,765 .

473. People ex rel. Gallo v. Acuna, 929 P.2d 596, 597 (Cal. 1997).

474. RENDLEMAN, supra note 146, at 1127-28 (discussing three obscenity injunctions); Ardia, supra note 1, at 52-57 (discussing four defamation injunctions). Ardia says "tailoring" for what I call drafting. See Ardia, supra note 1, at 29. 
Lokki to remove or take down the false statement from GripeLex presents fewer drafting issues. The alternative injunctions follow.

First, the judge may abate her tort by forbidding Lokki from saying anything at all about Baldder, in effect, a silencing order. If Lokki were the proprietor of the website, the judge could order it shut down. A few years ago, I called an obscenity silencing and shutdown injunction a "hardcore prior restraint." 475

The trial judge's injunction in Tory v. Cochran was in this first class because it forbade Tory from saying anything about Cochran in public. ${ }^{476}$ Justice Breyer, striking the injunction down, referred to it as an "overly broad prior restraint," in effect reversing the injunction for two separate reasons. ${ }^{477}$ The trial judge's injunction in Tory was too broad because it forbade defendant's potential speech that is not defamatory. ${ }^{478}$ It was a prior restraint because it forbade expression that the defendant had not uttered. Suppose defendant Tory changed his mind and heaped effusive praise on the plaintiff, such as, "Johnnie Cochran is the world's greatest lawyer"?

The trial judge in Organization for a Better Austin v. Keefe had enjoined the defendants from distributing leaflets, a proscription that forbade a lot of defendants' protected speech, probably including distributing The Chicago Tribune, a daily newspaper. ${ }^{479}$ An injunction that requires the defendant to be silent is an improper prior restraint. ${ }^{480}$

Second, the judge may grant Baldder an injunction that forbids Lokki from "defaming or libeling" Baldder. Under Federal Rule 65(d)(1)(C) or a state's equivalent, the injunction itself should also define defamation and libel. ${ }^{481}$ If, for example, Baldder charges Lokki with contempt of an antidefamation injunction for calling him a turkey, she may defend contempt by showing that turkey is name calling, but not defamatory. ${ }^{482}$

475. Doug Rendleman, Civilizing Pornography: The Case for an Exclusive Obscenity Nuisance Statute, 44 U. CHI. L. REV. 509, 551-52 (1977) [hereinafter Rendleman, Civilizing].

476. Tory v. Cochran, 544 U.S. 734, 736 (2005).

477. Id. at 738. Professor Mayton argues that orders that are prior restraints are those the judge would reject for other reasons, overbreadth, or vagueness, an approach that leaves the prior restraint doctrine nugatory with no work at all to do. See Mayton, supra note 61, at 268.

478. Ardia, supra note 1, at 65-68; Chemerinsky, supra note 287, at 171-72 (arguing that a Tory-type injunction against all of a defendant's future speech against a plaintiff is too broad).

479. Org. for a Better Austin v. Keefe, 402 U.S. 415, 417 (1971).

480. See Tory, 544 U.S. at 738.

481. See FED. R. CIV. P. 65(d)(1)(C); Volokh, supra note 2 (manuscript at 34).

482. See 3 DoBBS, HAYDEN \& BUBLICK, supra note 7, § 572, at 325-27. 
The injunction in Near was in the second class. ${ }^{483}$ As the Minnesota Supreme Court correctly observed, it resembled an order forbidding further defamation. ${ }^{484}$ Jay Near ceased publishing his newspaper after the trial judge's preliminary injunction. ${ }^{485}$ But he could have continued to publish. And, if the plaintiffs charged him with contempt, Near could have argued that he had published a non-libelous paper that did not violate the injunction. ${ }^{486}$

A court today ought to rule that a no-defamation injunction is both too broad and too vague. It forbids the defendant's expression that had not already been found to be defamatory, and it provides the defendant with insufficient notice of expressions that would violate it. ${ }^{487}$

A New Jersey court expressed a contrasting view in Chambers v. Scutieri. ${ }^{488}$ That court approved an injunction that forbade the defendant from "continuing acts of extortion" and "future extortion or attempted extortion." 489 The appellate court said that the injunction was not too broad because it followed the criminal law. ${ }^{490}$ In addition, it was not too vague. ${ }^{491}$ With respect, that decision seems vulnerable. The legal conclusions the court approved seem to be both too vague and too broad for a constitutional injunction.

Third, is a removal or takedown injunction. In Kinney v. Barnes, the Texas court said that the trial court could approve an injunction that ordered the defendant to delete a comment that the court had found to be defamatory

483. See Near v. Minnesota ex rel. Olson, 283 U.S. 697, 705-706 (1931).

484. Id. at 706. The United States Supreme Court majority may have thought it was a shutdown injunction, but the dissent did not. See id. at 735-36 (Butler, J., dissenting); see also Ave. Book Store v. City of Tallmadge, 459 U.S. 997, 998-99 (1982) (White, J., dissenting from denial of certiorari); Fehlhaber v. North Carolina, 675 F.2d 1365, 136566 (4th Cir. 1982).

485. See Near, 283 U.S. at 703-07.

486. Rendleman, Civilizing, supra note 475, at 555. In Kingsley Books, Inc. v. Brown, the Supreme Court misstated Near as a silencing injunction, in this article's first class. See 354 U.S. 436, 445 (1957). It said that the Minnesota statute in Near allowed a court to enjoin a defendant from publishing "future issues of a publication because its past issues have been found offensive." Id.

487. See Metro. Opera Ass'n, Inc. v. Local 100, Hotel Emps. \& Rest. Emps. Int'1 Union, 239 F.3d 172, 174 (2d Cir. 2001) (finding the terms "fraudulent or defamatory" were too vague because it did not specify what defamatory statements); Ardia, supra note 1, at 53. Ardia's class three injunction would ban certain enumerated statements, maybe not defamatory. It would fail as too broad because it enjoins speech not previously adjudged to be defamatory. Ardia, supra note 1, at 54-55; see CapStack Nashville 3, LLC v. MACC Venture Partners, No. 2018-0552-SG, 2018 WL 3949274, at *3 (Del. Ch. Aug. 16,2018 ) (refusing an interlocutory injunction to forbid defendants from "making defamatory and libelous statements about Plaintiffs.").

488. Chambers v. Scutieri, No. A-4831-10T1, 2013 WL 1337935, at*1 (N.J. Super. Ct. App. Div. Apr. 4, 2013).

489. Id. at *1, *15.

490. See id. at $* 15$.

491. Id. at $* 7, * 15$. 
from its website. ${ }^{492}$ Because such an order did not forbid the defendant's future protected speech, it seems to me that the court correctly held that it was not a prior restraint. ${ }^{493}$

Fourth, in Balboa, the California Supreme Court approved an injunction that forbade Lemen from repeating statements the court had previously found to be defamatory. ${ }^{494}$ This, Ardia maintains, with my approbation, is not an improper prior restraint. ${ }^{49}$ As discussed above, in Kinney, the Texas court explicitly rejected this fourth type of injunction. ${ }^{496}$

The judge, in the better view, may enjoin only speech that the defendant has published, "specific statements the court or jury has found are defamatory." 497 This Article's hypothetical judge may forbid Lokki from again calling Baldder a thief. The judge may also order her to remove libel she has posted on GripeLex.

The judge's injunction that forbids the defendant from repeating only proved defamation is not a prior restraint because it only forbids the defendant from repeating or persisting in defamation, something that the judge has adjudicated to be bereft of First Amendment protection. ${ }^{498}$ If Lokki calls Baldder a "nutcase" or "an incompetent bungler," Baldder must either move to modify the injunction to include those terms or start a second lawsuit. The Texas court, plus many of my Washington and Lee law students, think that this type of anti-defamation injunction will be ineffective because the defendant can employ synonyms and wordplay. ${ }^{499}$ We return to this objection below.

\footnotetext{
492. 443 S.W.3d 87, 87 (Tex. 2014).

493. Id. at 99 .

494. Balboa Island Vill. Inn, Inc. v. Lemen, 156 P.3d 339, 342 (Cal. 2007).

495. Ardia, supra note 1, at 56-57 (citing Balboa Island Vill. Inn, 156 P.3d 339); see also Harvard Law Review Ass'n, Developments in the Law-Injunctions, 78 HARV. L. REV. 994, 1009 (1965). For those favoring "narrow" injunctions, see Bertelsman, supra note 157, at 321-22; Gold, supra note 300, at 253-56; Steve Tensmeyer, Constitutionalizing Equity: Consequences of Broadly Interpreting the "Modern Rule" of Injunctions Against Defamation, 72 N.Y.U. ANN. SURV. AM. L. 43, 51 (2017) (referring to approving such an injunction as "the modern rule"); Volokh, supra note 2 (manuscript at 48).

496. Kinney, 443 S.W.3d at 87.

497. Ardia, supra note 1, at 67. Dean Erwin Chemerinsky wrote that such an injunction is also a prior restraint. Chemerinsky, supra note 287, at 165-66. But he changed his position later. See Erwin Chemerinsky, Tucker Lecture, Law and Media Symposium, 66 WASH. \& LEE L. REV. 1449, 1460-61 (2009). As a scholar, he departed from his earlier position as an advocate and favored my working hypothesis, enjoining defamation sometimes. Id. He did not document his conclusion in detail. See id.

498. See Balboa Island Vill. Inn, 156 P.3d at 344-45; Ardia, supra note 1, at 38-41. 499. Kinney, 443 S.W.3d at 97.
} 
The obligor or who-must-obey issue is the final point about drafting an injunction. An injunction typically requires three groups to obey: first, defendants; second, defendant's agents plus agent-synonyms; and, third, others with notice of the injunction "in active concert or participation" with defendants. ${ }^{500}$

The California court in Balboa said an injunction that forbids a defendant's defamation would not be effective against any nonparties. ${ }^{501}$ This seems correct. An injunction will forbid the defendant's expression that is also a tort, outside the First Amendment's ambit.

In contrast, because the defendant had hired picketers to oppose the plaintiff, the New Jersey court approved an injunction that also covered non-defendants, apparently the defendant's agents. ${ }^{502}$ On balance, I think that court went too far. A nonparty who repeats the defendant's defamatory statement should be added as a party defendant who is entitled to show meaning and context separate from the enjoined defendant. ${ }^{503}$ The plaintiff may add a website like GripeLex as a relief defendant that, although not a tortfeasor, is necessary for effective relief.

An injunction that forbids defamation should only apply to named defendants. A nonparty, even the defendant's agent, should have the opportunity to re-litigate the defamation issue in a separate lawsuit or to be added as a party defendant in the underlying lawsuit. In short, a court should not require a nonparty to obey the defendant's anti-defamation injunction.

500. Fed. R. Civ. P. 65(d)(2); Doug Rendleman, Beyond Contempt: Obligors to Injunctions, 53 TEX. L. REV. 873, 896-97 (1975) (citing FED. R. CIV. P. 65(d)(2)).

501. See Balboa Island Vill. Inn, 156 P.3d at 352-53.

502. Chambers v. Scutieri, No. A-4831-10T1, 2013 WL 1337935, at*15 (N.J. Super. Ct. App. Div. Apr. 4, 2013).

503. Chemerinsky, supra note 287 , at 161-62. 


\section{Enforceability}

The internet is international. An injunction that forbids defendant's internet defamation may not be effective because the injunction may be followed by copying and mirror sites, some overseas. ${ }^{504}$ Potential defendants may be beyond the court's jurisdiction over persons and territory. ${ }^{505}$

The structure of the internet means that take-down orders are potentially ineffective because others can copy and store the content. ${ }^{506}$ In March 2019, ISPs were unable to stop international dissemination on Facebook of the massacre in the mosque in Christchurch, New Zealand. ${ }^{507}$

Ardia wrote that the judge should not grant an injunction that will be futile. ${ }^{508}$ He favors an injunction only for a "limited community," a "limited audience," in other words only for the defendant's banners, handbills, flyers, and billboards but not for the defendant's internet defamation. ${ }^{509}$

Ardia's objection seems pessimistic to me. An out-of-state defendant's defamation may be contact enough for in personam jurisdiction over it in

504. Bank Julius Baer \& Co. v. Wikileaks, 535 F. Supp. 2d 980, 985 (N.D. Cal. 2008).

505. See, e.g., Neb. Press Ass'n v. Stuart, 427 U.S. 539, 565-66 (1976); Ardia, supra note 1, at 7; Douglas Rendleman, Free Press-Fair Trial: Review of Silence Orders, 52 N.C. L. REV. 127, 151 (1973).

506. See Damien Cave, Australian Gag Order Stokes Global Debate on Secrecy, N.Y. TIMES (Dec. 14, 2018), https:/www.nytimes.com/2018/12/14/world/australia/australiagag-order-court.html [https://perma.cc/B8QG-3ELK]; A. Odysseus Patrick \& Rick Noack, With Australian Gag Order Lifted on Cardinal Pell Abuse Trial, Details Finally Spill Out, WASH. Post (Feb. 26, 2019), https://www.washingtonpost.com/world/asia pacific/withaustralian-gag-order-lifted-on-cardinal-pell-abuse-trial-details-finally-spill-out/2019/02/ 26/4d214322-39da-11e9-b10b-f05a22e75865_story.html?utm_term=.4d2081b955a1 [https:// perma.cc/6CBJ-SB2M].

507. Charlotte Graham-McLay, Austin Ramzy \& Daniel Victor, Christchurch Mosque Shootings Were Partly Streamed on Facebook, N.Y. TIMES (Mar. 14, 2019), https://www. nytimes.com/2019/03/14/world/asia/christchurch-shooting-new-zealand.html [https://perma.cc/ D92D-8QF4] ("Harrowing first-person footage, apparently from a camera worn by a gunman as he attacked the Al Noor Mosque in the center of the city, was streamed on Facebook a grim milestone in the evolution of terrorism that raised questions about how tech companies can block extremists from using social media to spread hate and inspire violence.").

508. See Ardia, supra note 1, at 78, 80-83; Normann Witzleb, 'Equity Does Not Act in Vain': An Analysis of Futility Arguments in Claims for Injunctions, 32 SYDNEY L. REV. 503, 503-04 (2010).

509. Ardia, supra note 1, at 81-82. 
the plaintiff's state. ${ }^{510}$ Most defendants will obey the law as defined in a personalized injunction. ${ }^{511}$

The judge should not hinge an injunction on whether the defendant will obey because that holds the plaintiff's substantive rights hostage to the defendant's potential obduracy. Finally, the perfect is the enemy of the good. That the judge cannot prevent all of the defendant's violations does not mean that the judge should not forbid any of them. In an imperfect world of second-best remedies, Ardia's requirement that an injunction must be effective asks too much of a real-world judicial solution.

\section{Administering the Injunction}

Having granted the plaintiff an injunction, the judge must administer it. The two formal phases of administering an injunction are the motion to modify-dissolve and contempt for violation.

\section{Motion to Modify-Dissolve}

Once the judge has granted the plaintiff's motion for an injunction, both the defendant and the plaintiff may move to modify or dissolve it because either the law or the factual setting has changed..$^{512}$

A judgment for money damages, as distinguished from an injunction, is entitled to res judicata preclusion. ${ }^{513}$ The rules circumscribe a judgment loser's ability to reopen or escape a money judgment. ${ }^{514}$ If the time to reopen it has expired, an incorrect money judgment perpetuates error. If the defamation judgment above was for money damages and several years had passed when the appellate court reversed the substantive rule, the plaintiff, relying on preclusion, would keep the money. ${ }^{515}$ On the other hand:

It is one thing to say that, once a money judgment has been paid and appeals have been exhausted, the transaction is over, and quite another to say that a party may be required under threat of contempt sanctions to continue complying with an injunction that no longer makes legal or factual sense. ${ }^{516}$

Suppose a defendant orally accused a plaintiff of being "a queer." She is enjoined not to repeat that epithet. Then the state's courts hold that an

510. See Gubarev v. Buzzfeed, Inc., 253 F. Supp. 3d 1149, 1152, 1160-61 (S.D. Fla. 2017).

511. RENDLEMAN, supra note 146, at 625; Bray, supra note 382, at 1112-13.

512. See FED. R. CIV. P. 60(b)(5).

513. See, e.g., Reed v. McKune, 298 F.3d 946, 950-51 (10th Cir. 2002).

514. See HAZARD, LEUBSDORF \& BASSETT, supra note $321, \S 15.15$, at 719.

515. See Restatement (THIRD) OF RESTITUTION AND UnJUst ENRICHMENT $\S 18 \mathrm{cmt}$. a, n.a (Am. LAw Inst. 2011) (citing Marriot v. Hampton (1967) 101 Eng. Rep. 969, 969).

516. HAZARD, LEUBSDORF \& BASSETT, supra note $321, \S 15.15$, at 719. 
oral accusation of homosexuality is not slander per se. ${ }^{517}$ The judge should respond to the defendant's motion by dissolving the injunction because the law has changed and the defendant's conduct enjoined is no longer a tort contrary to law. The California court in Balboa discussed the defendant's use of the California version of this motion when the factual or legal context changes. ${ }^{518}$

Blasi argues against an injunction as a prior restraint that an injunction's duration is not limited. ${ }^{519}$ The availability of the defendant's motion to modify or dissolve an injunction refutes that argument. If a defamation judgment was an injunction and the substantive rule changes, the defendant's motion to dissolve it should succeed.

The coin has two sides. In our hypothetical, the judge has granted plaintiff Baldder an injunction that forbids defendant Lokki from calling Baldder a thief. Suppose that after the judge grants the injunction, Lokki learns that Baldder stole another condo owner's coin collection. He is indeed a thief. After his peculations are uncovered, may Lokki refer to Baldder as a thief? Once the truth is out, Lokki's motion to dissolve the injunction is a less risky technique than ignoring the injunction and risking contempt. It should succeed. ${ }^{520}$

Emerson equated the injunction in Near $v$. Minnesota ex rel. Olson with executive censorship because "the practical effect of the injunction was that the publishers, in order to avoid risk of summary punishment for contempt, had to clear material in advance with the judge." ${ }^{21}$ The Texas court said that the defendant's opportunity to move to avoid an anti-defamation injunction did not answer the concern that it was an improper prior restraint. ${ }^{522}$

517. Yonaty v. Mincolla, 945 N.Y.S.2d 774, 777-79 (App. Div. 2012). See generally Case Comment, Tort Law-Defamation-New York Appellate Division Holds that the Imputation of Homosexuality Is No Longer Defamation Per Se.-Yonaty v. Mincolla, 126 HARV. L. REV. 852, 852 (2013) (quoting Yonaty, 945 N.Y.S.2d at 776).

518. Balboa Island Vill. Inn, Inc. v. Lemen, 156 P.3d 339, 353 (Cal. 2007).

519. See Blasi, supra note 61 , at 19.

520. California rejects the collateral bar rule. Tory v. Cochran, 544 U.S. 734, 739 (2005) (Thomas, J., dissenting). The defendant could violate the injunction and raise the erroneous injunction as a defense to criminal contempt. Id. at 740 (citing People v. Gonzalez, 910 P.2d 1366, 1375 (Cal. 1996)).

521. EMERSON, supra note 156, at 506; see also Near v. Minnesota ex rel. Olson, 283 U.S. 697, 712 (1931) ("[T] he renewal of the publication . . would constitute a contempt and ... would lay a permanent restraint upon the publisher, to escape which he must satisfy the court as to the character of a new publication.").

522. See Kinney v. Barnes, 443 S.W.3d 87, 98 (Tex. 2014) (quoting Balboa Island Vill. Inn, 156 P.3d at 353). 
Could an injunction threaten censorship because the defendant could move to the trial judge to construe, modify, or dissolve it? Would the defendant's motion to construe, modify, or dissolve an injunction threaten free expression as much as executive-licensing censorship? ${ }^{523}$ I do not think so. An injunction that forbids the defendant from repeating proved defamation may become improper because the defendant's mental state may change, the law may change, the context may change, or the false statement may become true. ${ }^{524}$ Although the Texas court disagreed, the judge's response to a defendant's post-injunction motion to modify or clarify because of a legal or factual change is a part of the injunction process that should be available for an injunction against the defendant's defamation. ${ }^{525}$ The risk that the judge may develop a proprietary attitude toward an injunction is one the system needs to accept. $^{526}$

\section{Contempt}

Contempt is the plaintiff's remedy when a defendant violates an injunction. ${ }^{527}$ Courts distinguish civil contempt, composed of compensatory contempt and coercive contempt, from criminal contempt. ${ }^{528}$ This distinction guards the boundary between civil procedure for civil contempt and the more demanding criminal procedure for criminal contempt. ${ }^{529}$

A judge imposes compensatory contempt and criminal contempt after the defendant has violated the injunction and it is too late to coerce the defendant to obey it. ${ }^{530}$ Compensatory contempt and criminal contempt both lead to substitutes for the plaintiff's substantive right, a money award or a criminal sanction. ${ }^{531}$ On the other hand, a judge employs coercive contempt

523. See Ardia, supra note 1, at 54 (quoting Near, 283 U.S. at 713); see also Wilson v. Superior Court, 532 P.2d 116, 122-23 (Cal. 1975); Frederick Schauer, Fear, Risk and the First Amendment: Unraveling the "Chilling Effect," 58 B.U. L. REV. 685, 727-30 (1978); Harvard Law Review Ass'n, supra note 495, at 1008-09, 1011-12.

524. See Balboa Island Vill. Inn, 156 P.3d at 356 (Kennard, J., concurring and dissenting); see also Tensmeyer, supra note 495, at 56-58 ("'II]f what was adjudicated was something narrower, such as certain words in a certain context, an injunction may extend only to uses of those words in that context.").

525. See Kinney, 443 S.W.3d at 95 (quoting Hajek v. Bill Mowbray Motors, Inc. 647 S.W.2d 253, 255 (Tex. 1983)); Gold, supra note 300, at $256 \&$ n.118. Motions to modifydissolve, Professor Volokh's Article adds, are expensive and time consuming. Volokh, supra note 2 (manuscript at 31-32).

526. Balboa Island Vill. Inn, 156 P.3d at 357 (Kennard, J., concurring and dissenting) (quoting Near, 283 U.S. at 713).

527. RENDLEMAN, supra note 146, at 629.

528. Id.

529. See id.

530. See id.

531. See id. 
to achieve the defendant's obedience to the plaintiff's rights that the injunction protects. ${ }^{532}$ In all three forms of contempt, defendants may lose money; in coercive contempt and criminal contempt, contemnors may also lose their liberty. ${ }^{533}$

\section{Violation}

Our discussion of contempt begins with the issue of whether the defendant violated the injunction.

A Balboa injunction that forbids the defendant from making specific statements may not stop the defendant's defamation. ${ }^{534}$ Perhaps, as mentioned above, an injunction that forbids specific statements would be futile because the defendant will resort to variations, synonyms, and wordplay. ${ }^{535}$ Would the defendant's synonym of the defamatory remark violate the injunction?

Returning to Lex, Lokki thinks she can circumvent the injunction that forbids her from calling Baldder a thief with synonyms crook, embezzler, or larcenist. So Lokki calls Baldder a larcenist instead of a thief. Baldder files a show cause motion to charge her with contempt. Should the judge construe thief to include larcenist? ${ }^{536}$

How literally should the judge read an injunction to decide whether the defendant contemnor's conduct violated it? The difference between the civil contempt and criminal contempt affects my answer.

Civil contempt, compensatory contempt or coercive contempt, seems to me to be the more likely remedy for a defendant's violation of an antidefamation injunction. The plaintiff might be entitled to a more expansive and liberal reading of an injunction in civil contempt that will not lead to punishment.

An example: A federal judge considered whether an injunction that forbade a defendant's trademark infringement, "PLAY-MEN," in a printed magazine applied several years later to her infringement in an internet website. ${ }^{537}$ The judge replied that it did:

532. See id.

533. See id.

534. See supra Part III.

535. Kinney v. Barnes, 443 S.W.3d 87, 97 (Tex. 2014).

536. Compare Ardia, supra note 1, at 30 (rephrasing an anti-perjury injunction to forbid "lie," "untruth," "deceptive," and "prevarication"), with Chemerinsky, supra note 287, at $171-72$.

537. Playboy Enters., Inc. v. Chuckleberry Publ'g, Inc., 939 F. Supp. 1032, 1033 (S.D.N.Y. 1996). 
The purpose behind the Injunction was to restrict the ability of Defendant to distribute its product in the United States, where it has been found to infringe upon the trademark of Playboy. Allowing the Defendant to contravene the clear intent of the Injunction by permitting it to distribute its pictorial images over the Internet would emasculate the Injunction. The Injunction's failure to refer to the Internet by name does not limit its applicability to this new medium. Injunctions entered before the recent explosion of computer technology must continue to have meaning. 538

The judge found that defendant had violated the injunction and imposed a combination of civil contempts: a second injunction, compensatory contempt, a coercive contempt fine payable to plaintiff, plus costs and attorney fees. ${ }^{539}$

Suppose the judge grants the plaintiff an injunction against the defendant's specified defamation. The judge's injunction has both prohibitory and mandatory provisions: it forbids or prohibits the defendant from calling the plaintiff a thief and it requires or mandates the defendant to remove or take down the defamatory accusation on the gripe site. ${ }^{540}$ We will use this example to examine the three forms of contempt, compensatory contempt briefly, coercive contempt, and criminal contempt.

Suppose that after the judge forbids Lokki from repeating her defamation, defendant pickets Baldder's business with a sign calling him a thief. Baldder may file show cause and the judge may impose compensatory contempt to order the defendant to pay the plaintiff money to compensate him for his loss from her defamation. The judge should base the plaintiff's award of money for compensatory contempt on his damages for her tort of defamation because a judge should usually measure a plaintiff's compensatory contempt award to resemble the underlying tort damages. ${ }^{541}$

With compensatory contempt, the judge awards the plaintiff the defendant's money that the judge had previously vetoed as an inadequate remedy. ${ }^{542}$ Here, defendant's synonyms for thief like crook, embezzler, or larcenist might lead to a compensatory contempt award just as they would lead to an award of compensatory damages if sued over separately. Although, in addition to committing a tort, the defendant has violated a court order, criminal contempt seems to me to be less likely than compensatory contempt for a defendant's tort that is not also a statutory crime.

Compensatory contempt and criminal contempt parallel, respectively, the plaintiff's civil action for damages and the state's criminal prosecution. ${ }^{543}$

538. Id. at 1037 .

539. Id. at $1037-41,1044$.

540. See, e.g., Kinney, 443 S.W.3d at 99.

541. See Doug Rendleman, Compensatory Contempt: Plaintiff's Remedy When a

Defendant Violates an Injunction, 1980 U. ILL. L.F. 971, 985-86.

542. Id. at 971 .

543. Id. at 971-92. 
On the other hand, coercive contempt is unique to enforcement of an injunction. ${ }^{544}$ The judge using coercive contempt will pressure the defendant to let the plaintiff enjoy his substantive right to be free of defamation. This keeps the promise the judge made when she decided that money damages were an inadequate remedy for the plaintiff and the judge's decision to grant an injunction instead of awarding damages.

The judge will employ coercive contempt to achieve the defendant's obedience. ${ }^{545}$ The purpose of coercive contempt is to secure the plaintiff's very rights for which money damages will be an inadequate remedy. ${ }^{546}$ The judge has many coercive contempt options. One such option is for a judge to re-enjoin the defendant with a schedule of fines that will be imposed for future violations. ${ }^{547}$

Suppose that defendant Lokki had posted her defamation on the GripeLex website and the judge's mandatory injunction orders her to remove it, to "take it down" in the vernacular. Lokki refuses to delete her false statement from the gripe-site. The judge may use coercive contempt to require her to comply. The judge's chief coercive contempt tools are either to confine Lokki in jail or to impose a staged, usually daily, money fine. ${ }^{548}$ Both techniques coerce Lokki to honor the plaintiff's rights. Several days of fines or a short time in the county jail may convince her to remove the offensive remark. Coercive contempt measures end when the contemnor obeys the order. ${ }^{549}$ They remain civil contempt because she can obey and the fines sanction will end; in the always-quoted metaphor, defendants like Lokki "carry the keys of their prison in their own pockets."

In coercive contempt, the usual ban on incarcerating a defendant without criminal procedural protection is suspended. ${ }^{551}$ Coercive contempt confinement has an awesome potential for abuse because it concentrates power in one trial

544. See id. at 971.

545. RENDLEMAN, supra note 146, at 769.

546. Rendleman, supra note 541, at 971.

547. RENDLEMAN, supra note 146, at 769-70.

548. See id. at 769. Volokh's Article discusses coercive contempt to enforce a takedown order. Volokh, supra note 2 (manuscript at 14, 35). It makes an interesting point that would forbid coercive contempt confinement for a First Amendment-related violation because there has not been any criminal procedure. Id.

549. RENDLEMAN, supra note 146, at 769-70.

550. In re Nevitt, 117 F. 448, 461 (8th Cir. 1902).

551. Doug Rendleman, Disobedience and Coercive Contempt Confinement: The Terminally Stubborn Contemnor, 48 WASH. \& LEE L. REV. 185, 190 (1991). 
judge without a jury to enter an order and then to incarcerate the defendant to enforce the order without the traditional checks of criminal procedure. ${ }^{552}$

My conclusion about coercive contempt for a defendant's breach of an anti-defamation injunction is a mixed one. On the one hand, the defendant's defamation is not protected speech. After adversary procedure, the judge has found that the defendant's libel tort exists and that money damages are inadequate for the plaintiff. Compensatory contempt indemnifies the plaintiff's past injury, but it does not forbid the defendant's future violation. The preventive relief of an injunction is an important remedy for an aggrieved plaintiff. The judge ought to be willing to coerce the defendant to secure the plaintiff's right to be free of the defendant's tort.

On the other hand, the judge's focused power in coercive contempt is troublesome. The defendant's expression is involved, albeit expression outside the First Amendment's protective ambit. The coercive-contempt judge should engage in careful fact finding and consider lesser coercive measures than jail, for example, a daily money fine. Just as the judge can appoint someone to make a deed when a specific-performance defendant refuses, the judge should consider appointing a surrogate to excise the offending remark. ${ }^{553}$ Another possibility is to add the third party as a relief defendant, not liable under substantive law, but necessary for effective relief. Trial judges and appellate courts should consider a stay and a prompt appeal before a defendant's coercive contempt confinement begins. ${ }^{554}$

Although I do not think that criminal contempt is the most likely solution here, a defendant who violates an injunction can be charged with, and convicted of, criminal contempt. An injunction, among other things, is the equivalent of a personalized criminal statute. The judge wields criminal contempt, like compensatory contempt, after the defendant has disobeyed the injunction. ${ }^{555}$

In the federal system and in some states, the public authorities maintain criminal contempt. ${ }^{556}$ The purpose of criminal contempt is to punish and deter the defendant's disobedience and disrespect. ${ }^{557}$ Although a contemnor's criminal contempt fine or imprisonment does not benefit the plaintiff

552. Id. at 190, 208.

553. See, for example, FeD. R. CIV. P. 70 and state equivalents.

554. See 28 U.S.C. § 1826(a)-(b) (2012).

555. Rendleman, supra note 541, at 971. Volokh's Article emphasizes criminal contempt a lot more than this Article. It builds much of its analysis on criminal contempt punishment; many of its conclusions are about criminal contempt. See Volokh, supra note 2 (manuscript at $63)$.

556. See Young v. United States ex rel. Vuitton et Fils S.A., 481 U.S. 787, 800 (1987); RENDLEMAN, supra note 146, at 872-76.

557. RENDLEMAN, supra note 146, at 629. 
directly, it deters the defendant by structuring incentives to avoid repeating the breach which benefits the plaintiff indirectly. ${ }^{558}$

Here we return to the question of whether the defendant violated the injunction, this time in criminal contempt. The Article returns to the federal judge who was deciding whether an injunction against the defendant's trademark infringement in a printed magazine applied several years later to its infringement in defendant's internet website. ${ }^{559}$ A criminal-contempt judge should not rely on purpose and intent to read an anti-defamation injunction spaciously. ${ }^{560}$ Contempt or criminal punishment for speech, as such, even false speech, ought to be exceptional. ${ }^{561}$ The criminal contemnor ought to be entitled to the same literal interpretation of an injunction that a court would accord to a criminal statute.

Thief, for example, should not include larcenist to qualify the defendant for criminal contempt. The plaintiff should move for civil contempt and to modify the injunction to include the defendant's variation or synonym among the injunction's forbidden terms. If the defendant violates a modified injunction, that misconduct could be charged as criminal contempt.

In Kinney v. Barnes, the plaintiff sought an injunction that forbade "the same or similar" libel. ${ }^{562}$ If the court had granted those terms, "the same" libel could support either civil contempt or criminal contempt, but "similar" libel would support civil contempt but not criminal contempt. ${ }^{563}$

\section{The Collateral Bar Rule}

The collateral bar rule is an important feature of criminal contempt. When the defendant is charged with criminal contempt for breaching an injunction, the collateral bar rule prevents the defense that the injunction is substantively incorrect. ${ }^{564}$ Under the collateral bar rule, a criminal contemnor cannot argue to refute criminal contempt that the injunction is substantively erroneous, even that it is unconstitutional. ${ }^{565}$ The defendant

558. See, e.g., Gompers v. Bucks Stove \& Range Co., 221 U.S. 418, 441-42 (1911).

559. See Playboy Enters., Inc. v. Chuckleberry Publ'g, Inc., 939 F. Supp. 1032, 1037 (S.D.N.Y. 1996).

560. See id. at 1040 .

561. See, e.g., United States v. Alvarez, 567 U.S. 709, 723 (2012).

562. Kinney v. Barnes, 443 S.W.3d 87, 89 (Tex. 2014).

563. Id. at 93, 97.

564. Walker v. City of Birmingham, 388 U.S. 307, 320 (1967) (quoting Fields v. City of Fairfield, 143 So. 2d 177, 180 (Ala. 1962)).

565. Id. 
must follow a direct attack, either a motion to modify or dissolve the injunction or an appeal, not a collateral attack in criminal contempt. ${ }^{566}$

Suppose, first, that the judge has forbidden the defendant from calling the plaintiff a thief. The defendant pickets the plaintiff's office with a sign calling the plaintiff a thief. If it turns out that the plaintiff is a thief, the contemnor would be acquitted of criminal contempt, except for the collateral bar rule.

Suppose, second, that an injunction forbids the defendant from picketing within 500 feet of the plaintiff's abortion clinic. Suppose, as is likely, that a 500-foot buffer zone violates the First Amendment because it forbids too much expression. But because of the collateral bar rule, the judge may nevertheless convict the defendant who picketed 475 feet from the clinic of criminal contempt for expression that, in retrospect, the First Amendment allows.

In its leading collateral bar rule decision, Walker v. Birmingham, the Supreme Court approved the collateral bar rule as a state rule of judicial administration that reprobated the contemnor's disrespect for the court and court orders. ${ }^{567}$ But the Court was unwilling to accept the collateral bar rule without qualification. It introduced two exceptions: the transparently invalid exception and the timely challenge exception. ${ }^{568}$

If the injunction the defendant violated is so far off the mark substantively that the court can label it "transparently invalid," then defendants can violate it, interpose its incorrectness in criminal contempt, and take their chances that the injunction is incorrect. ${ }^{569}$ Similarly, if defendants lacks a procedural opportunity for a "timely challenge" to the injunction, then, also, they may violate it and argue against it on the merits. ${ }^{570}$

566. See generally RENDLEMAN, supra 146, at 875-903 (discussing the Collateral Bar Rule); Rendleman, Irreparability, supra note 281, at 1377-78; Doug Rendleman, More on Void Orders, 7 GA. L. REv. 246, 248-49 (1973) [hereinafter Rendleman, Void Orders]; Doug Rendleman, Toward Due Process in Injunction Procedure, 1973 U. ILL. L.F. 221, 225-27 [hereinafter Rendleman, Toward]; John R.B. Palmer, Note, Collateral Bar and Contempt: Challenging a Court Order After Disobeying It, 88 CoRNELL L. REv. 215, 22124 (2002).

567. Walker, 388 U.S. at 320.

568. Id. at 315,318 .

569. In re Providence Journal Co., 820 F.2d 1342, 1347 (1st Cir. 1986), modified, 820 F.2d. 1354, 1354-55 (1st Cir. 1987) (per curiam) (finding that a prior restraint on pure speech by the press was presumptively unconstitutional, thus satisfying the "transparently invalid" exception). Although the United States Supreme Court granted certiorari, it dismissed the case because the special prosecutor lacked standing. United States v. Providence Journal Co., 484 U.S. 814 (1987).

570. Rendleman, Void Orders, supra note 566, at 262-65; Rendleman, Toward, supra note 566 , at $228-29$. 
Several state courts, including both Texas's and California's, reject the collateral bar rule. ${ }^{571} \mathrm{In}$ an abortion-clinic contempt appeal, a Texas Supreme Court justice observed that "I cannot see how justice is served by leaving imprisoned those found to have violated an order shown to be unconstitutional." 572 In California, a person affected by an injunctive order "may conclude that the exigencies of the situation or the magnitude of the rights involved render immediate action worth the cost of peril." 573

Justice Baxter's concurring opinion in Balboa developed California's rejection of the collateral bar rule. ${ }^{574}$ A defamation-injunction defendant may violate the injunction and defend criminal contempt by arguing successfully that the injunction was a prior restraint. ${ }^{575}$

What should be the role of the collateral bar rule in criminal contempt for breach of an injunction that forbids the defendant's defamation? Suppose a Balboa anti-defamation injunction is not a forbidden prior restraint and passes the constitutional test. California and Texas law allow a criminalcontempt contemnor to violate it and then to argue as a defense to contempt that the injunction conflicts with the First Amendment. ${ }^{576}$

Suppose another state judge in a state with the collateral bar rule enjoins a defendant's defamation. Then is it improper or unconstitutional for that state judge to wield the collateral bar rule to prevent the defendant contemnor from arguing against the injunction in contempt?

Scholars' answers vary. Professor Hunter wrote that the collateral bar rule strengthens an injunction. ${ }^{577}$ Blasi opposes injunctions in both collateral bar rule and non-collateral bar rule jurisdictions. ${ }^{578} \mathrm{He}$ argues that an injunction

571. Ex parte Tucci, 859 S.W.2d 1, 2 n.4 (Tex. 1993); People v. Gonzalez, 910 P.2d 1366, 1375 (Cal. 1996); In re Berry, 436 P.2d 273, 281 (Cal. 1968).

572. Tucci, 859 S.W.2d at 1 n.4.

573. Berry, 436 P.2d at 281; see also Gonzalez, 910 P.2d at 1375.

574. See Balboa Island Vill. Inn, Inc. v. Lemen, 156 P.3d 339, 353 (Cal. 2007) (Baxter, J., concurring).

575. Id. The dissenting opinion in Balboa maintained that Justice Baxter asked too much of defendant. Id. at 361 (Werdegar, J., dissenting). Justice Thomas's dissenting opinion in Tory v. Cochran also relies on California's rejection of the collateral bar rule. 544 U.S. 734, 739-40 (2005) (Thomas, J., dissenting).

576. See Kinney v. Barnes, 443 S.W.3d 87, 98 (Tex. 2014) ("We think it is no answer that a person must request the trial court's permission to speak truthfully in order to avoid being held in contempt."); see also Balboa Island Vill. Inn, 156 P.3d at 353 (Baxter, J., concurring).

577. See Hunter, supra note 156, at 286-87.

578. See Blasi, supra note 61, at 92-93. 
or contempt court should retain the presumption against prior restraints. ${ }^{579}$ Jeffries, who does not oppose injunctions forbidding defamation, wrote that a state can have the collateral bar rule and grant an injunction that is not a banned prior restraint if the defendant can take or could have achieved prompt review. ${ }^{580}$ Mayton favors the collateral bar rule for breach of a litigated injunction but not for an injunction after "summary and incomplete" process. ${ }^{581}$ Redish also agrees, if the defendant has had a full and fair hearing, the judge may apply the collateral bar rule in contempt. ${ }^{582}$ Wells can take the collateral bar rule or leave it; it is not clear to her that the collateral bar rule causes an injunction to deter more than a criminal statute. ${ }^{583}$

Barnett wrote that a court should not apply the collateral bar rule to criminal contempt for violation of an injunction against expression. ${ }^{584} \mathrm{He}$ maintained that allowing adjudication of constitutionality in contempt protects expression better. ${ }^{55}$ In my view, Barnett's view is the better argument. The states without the collateral bar rule are wiser. A state that adheres to the collateral bar rule should suspend it if a defendant is charged with criminal contempt for an alleged violation of an anti-defamation injunction. ${ }^{586}$ Where the defendant's expression is at issue, re-litigating the injunction's correctness and the truth of the defendant's charged violation in criminal contempt is not too great a price for constitutional, legal, and factual accuracy.

This Article has compared an injunction to a damages judgment, asked whether the remedies differ enough to mean that a court should favor damages over an injunction, and argued that the differences do not always warrant different treatment. It has taken the reader through the injunction process, examined whether the judge might grant an injunction to a successful defamation plaintiff, and concluded that an injunction might be propitious. We are ready to analyze the leading prior restraint scholarship.

\section{SCHOLARS’ ARgUMENTS AgAINST PRIOR RESTRAINTS}

In dealing with important scholars' formidable arguments for the prior restraint doctrine, this Article continues to inquire whether disfavoring an

579. See id.

580. See Jeffries, supra note 162, 433.

581. Mayton, supra note 278, at 278 n.204.

582. See Redish, supra note 159, at 96-97, 96 n.155.

583. See Wells, supra note 141, at 62-64, 62 n.305. Volokh also seems to take an intermediate position on the collateral bar rule. See Volokh, supra note 2 (manuscript at 25,34$)$.

584. See Barnett, supra note 160, at 556-58.

585. See id.

586. See EMERSON, supra note 156, at 505-06; Redish, supra note 159, at 96-99, 96 n. 155 . 
injunction against the defendant's defamation makes sense from a legal and policy standpoint.

Blasi's Article celebrating Near's golden anniversary asked whether to regard an injunction as a repressive technique to regulate speech that is similar enough to executive licensing to be treated the same way. ${ }^{587}$ Blasi concluded that an injunction resembles executive licensing in unsatisfactory ways because both adjudicate abstractly in advance and contain an internal dynamic contrary to our premises about limited government. ${ }^{588}$

Emerson had expressed his "rational basis for the [prior restraint] concept":
A system of prior restraint is in many ways more inhibiting than a system of subsequent punishment: It is likely to bring under government scrutiny a far wider range of expression; it shuts off communication before it takes place; suppression by a stroke of the pen is more likely to be applied than suppression through a criminal process; the procedures do not require attention to the safeguards of the criminal process; the system allows less opportunity for public appraisal and criticism; the dynamics of the system drive toward excesses, as the history of all censorship shows. ... [A] system of prior restraint presents inherent dangers that make it highly disfavored as a form of regulation. 589

Blasi's and Emerson's reasons for the prior restraint doctrine, Redish wrote, were based on fallacies, speculation, unfounded factual assumptions, and confusion of substance and procedure. ${ }^{590}$ Their reasons "are irrelevant to [F]irst $[\mathrm{A}]$ mendment concerns, are equally true of subsequent punishment schemes, or are exclusively applicable to administrative rather than judicial restraints." ${ }^{\text {991 }}$ Jeffries, who took Redish's analysis another step, argued that the prior restraint doctrine has lost its analytical force and should be retired. ${ }^{592}$

To some extent, Blasi's and Emerson's critiques present a different frame of reference than this Article. Emerson more than Blasi emphasized alternatives that this Article sets aside, executive licensing and a criminal prosecution. ${ }^{593}$ This Article assumes that executive licensing is obsolete for the internet expression it considers. Moreover, this Article maintains that a criminal

587. Blasi, supra note 61 , at 14

588. See id. at $24,93$.

589. EMERSON, supra note 156, at 506.

590. Redish, supra note 159 , at 73.

591. Id. at 59.

592. Jeffries, supra note 162 , at 434 . Volokh writes that a specific injunction, granted after adequate adversary procedure, is not a prior restraint. Volokh, supra note 2 (manuscript at $16-17)$.

593. See EMERSON, supra note 156, at 163. 
prosecution also seems unlikely for internet defamation. Emerson compared executive licensing as a prior restraint to a criminal prosecution; he included an injunction almost as an incidental form of prior restraint. ${ }^{594}$ Similarly in their paired con and pro articles, Mayton and Hunter compare executive licensing with a criminal prosecution. ${ }^{595}$

Blasi's "excessive use" and Emerson's "overuse" or wider-range arguments in reality compare executive licensing, the prior restraint, with a criminal prosecution, the subsequent punishment. ${ }^{596}$ Under executive licensing, censorship will be more routine than a criminal prosecution: "[T]he censor's business is to censor." ${ }^{, 97}$ In addition to being superannuated in the internet world that this Article examines, executive censorship is unrelated to an injunction, a judicial remedy. Routine administrative censorship of the internet posting activity that this Article examines is not happening now and will not happen in the future in the United States. ${ }^{598}$

Both Blasi and Emerson de-emphasized alternatives that this Article considers and compares: an injunction and a damages judgment. An injunction is this Article's prior restraint. A judgment for money damages, punitive damages more certainly than compensatory damages, fills its bill as subsequent, as it were, punishment. Emerson disapproved executive licensing and an injunction as prior restraints; he preferred a criminal sanction as a subsequent punishment and a superior alternative to a prior restraint. ${ }^{599}$ He did not focus on the damages judgment as a subsequent-punishment alternative to a prior restraint in the form of an injunction. ${ }^{600}$

This Article, on the other hand, does not compare executive licensing and an injunction, prior restraints, to a criminal prosecution, subsequent punishment. It examines the libel tort leading to a civil remedy, an injunction or a judgment for money damages, sometimes both. It compares the two civil remedies for libel, an injunction and money damages.

594. Id.

595. See generally Hunter, supra note 156; Mayton, supra note 61.

596. See generally EMERSON, supra note 156; Blasi, supra note 61.

597. Freedman v. Maryland, 380 U.S. 51, 57 (1965).

598. China, among other nations, censors the internet. See Craig Timberg \& Jla Lynn Yang, Google Is Encrypting Search Globally. That's Bad for the NSA and China's Censors., WASH. POST (Mar. 12, 2014), https://www.washingtonpost.com/news/the-switch/wp/2014/ 03/12/google-is-encrypting-search-worldwide-thats-bad-for-the-nsa-and-china/?utm_term=. f85612b2b3fc [https://perma.cc/J8LJ-FGBP]. China erected its Great Firewall for internet censorship. Id. Google in turn challenges the censorship by encrypting internet searches from China. Id. Other nations that censor the internet are Vietnam and Saudi Arabia. Id. 599. See EMERSON, supra note 156, at 504 ("Even if the communication is subject to later punishment or can otherwise be restricted, it cannot be proscribed in advance through a system of prior restraint.").

600. Id. 
The best way to understand the difference between an injunction and a civil money judgment, or the less likely criminal prosecution, is chronological. If someone's misconduct is imminent but has not occurred or, if ongoing, is likely to continue or to be repeated, then a plaintiff may sue that person for an injunction as a preventive remedy. The private plaintiff or, less likely, the government authorities may sue a defendant for an injunction to forbid that defendant's future misconduct.

After the defendant's defamation, the civil plaintiff may sue the defendant seeking a money judgment. The authorities would also maintain the lesslikely criminal prosecution after the defendant's misconduct.

A civil plaintiff or a prosecutor does not choose initially between either an injunction, an action for money damages, or a criminal prosecution. The remedies are sequential: the injunction comes before the defendant's misconduct, the damages action or the criminal prosecution after it.

Arguments that are valid against executive licensing do not apply to an injunction. These include Blasi's and Emerson's "more," "wider," and "stroke of a pen," points as well as their arguments based on "audience reception," "limited government," and the inevitability of "excesses." 601

In addition, two of Blasi's points, the lack of public appraisal and the momentum to excess, are well grounded in relation to executive censorship, but not an injunction. Blasi's argument that a prior restraint improperly allocates authority between the state and the individual also appears to object more to executive licensing than to a private plaintiff's injunction. ${ }^{602}$ It makes a point about the size of the First Amendment, not the remedy. His arguments that an injunction, like executive licensing, "adversely affects" the way the public receives the defendant's messages, and that both are at odds with our premises about limited government, also only restate his earlier points about executive licensing and express his conclusion. ${ }^{603}$

Blasi argued that an injunction resembles executive licensing because it contains an "internal dynamic" that leads to its "excessive" use. ${ }^{604}$ This seems to equate a judge with a professional censor and to maintain that a judge considering a plaintiff's motion for an injunction will be as insensitive to free speech values as a bureaucratic censor.

601. EMERSON, supra note 156, at 504, 506; Blasi, supra note 61, at 43, 58, 63, 70.

602. See Redish, supra note 159 , at $72-73$.

603. Blasi, supra note 61 , at 64 .

604. Id. at 52-54. 
A little professional pride may be appropriate in response. A trial judge's education and earlier experience should militate against, perhaps obviate, insensitivity to First Amendment principles. The judicial process emphasizes adversary presentation and arguments, decisions constrained by constitutions, statutes or precedents, and written opinions with reasons. "The institution of the judiciary," Jeffries wrote, "is peculiarly well suitedin personnel, training, ideology, and institutional structure - to implement the ideals of the First Amendment." ${ }^{" 605}$ Moreover, an insensitive Equity judge would be equally insensitive presiding over a defendant's tort or criminal prosecution. Finally, as discussed above, civil procedure leading to an injunction should be more professional and careful than executive licensing and censorship, even that disciplined by Freedman v. Maryland's procedure. ${ }^{606}$ The speculative argument that an injunction is easier to obtain than a criminal prosecution fails for want of proof.

Blasi argued against prior restraints because adjudication is "abstract." That adjudication leading to an injunction will be abstract is questionable. In federal court, a plaintiff seeking an injunction must have "standing," a test designed to prevent an abstract dispute from reaching judgment. ${ }^{608}$ Before a United States court may grant an injunction, a plaintiff with standing must take the initiative and show the judge that an injunction is appropriate. ${ }^{609}$ Moreover, special maturity rules for an injunction should ensure an "imminent," concrete, and non-abstract dispute. ${ }^{610}$

To be preventive, an injunction has to be predictive. ${ }^{611}$ In our hypothetical, to convince the judge to grant a motion for an injunction, Baldder must show that Lokki has called him a thief, and he must convince the judge that, unless the judge orders her not to, Lokki is likely to continue or repeat the tort. When the judge enjoins the defendant from repeating a published statement that she has already found to be defamatory, abstractness does not seem to be a major risk. Finally, the factual issue in contempt, whether the contemnor violated the injunction, further reduces the abstract nature of the dispute.

605. Jeffries, supra note 162, at 427; see Mayton, supra note 61, at 250-51; see also Suzanna Sherry, Response, Liberty's Safety Net: Comments on "Judicial Activism," 16 GREEN BAG 2D 467, 476 (2013) ("I believe that federal judges as a group are among the most ethical, professional, and disinterested decision makers we have."). But see Hunter, supra note 156, at 292 (warning not to prefer judges over professional censors).

606. See Freedman v. Maryland, 380 U.S. 51, 58 (1965).

607. Blasi, supra note 61, at 24.

608. City of Los Angeles v. Lyons, 461 U.S. 95, 101-05 (1983) (distinguishing standing for an injunction from standing for damages).

609. See id. at 105 .

610. Reserve Mining Co. v. EPA, 514 F.2d 492, 528 (8th Cir. 1975).

611. See Blasi, supra note 61, at 11. 
Blasi maintained that an injunction operates "in advance" to prevent speech. ${ }^{612}$ The injunction, Emerson argued, "shuts off communication before it takes place." 613 Similarly, Professor Kalven wrote that the prior-restraint doctrine protects a person's opportunity for "civil disobedience." "[E]verything," he wrote, "or virtually everything, is entitled to be published at least once." ${ }^{615}$ Professor Bickel's metaphor to express this argument was that "[a] criminal statute chills, prior restraint freezes." 616 The United States Supreme Court and the Texas Supreme Court repeated that metaphor stating that, "[a] threat of criminal or civil sanctions after publication 'chills' speech, prior restraint 'freezes' it at least for a time." 617

In contrast, it is argued that a criminal statute or prosecution allows speech. ${ }^{618}$ This assures that everything will be heard. Thus, the argument proceeds, a court should disfavor an injunction and favor a criminal prosecution. The defendant's criminal prosecution occurs after her expression is disseminated while an injunction will have prevented that dissemination.

Take prior restraints out of the refrigerator to inquire whether the chillfreeze metaphor and its variations are accurate. The chill side of the metaphor is not always a low temperature. If a criminal statute carries a draconian sanction for conviction, say forty years for littering, and if the person is certain that the government will prosecute her, then the subsequent punishment in the form of a criminal statute may freeze a potential violator's ardor. ${ }^{619}$

612. Id.

613. EMERSON, supra note 156 , at 506.

614. Harry Kalven, Jr., The Supreme Court 1970 Term-Foreword: Even When a Nation Is at War, 85 HARV. L. REV. 3, 34 (1971).

615. Id.

616. Alexander M. Bickel, The Morality of Consent 61 (1975).

617. Neb. Press Ass'n v. Stuart, 427 U.S. 539, 559 (1976); see Kinney v. Barnes, 443 S.W.3d 87, 90 (Tex. 2014) (quoting BiCKEL, supra note 616, at 61).

618. Neb. Press Ass'n, 427 U.S. at 596 (quoting Craig v. Harney, 331 U.S. 367, 374 (1947)).

619. See KAUPER, supra note 45, at 61 (heavy subsequent sanctions operate the same way as a prior restraint); RICHARD A. POSNER, ECONOMIC ANALYSIS OF LAW § 29.3, 964 (9th ed. 2014) (stating that a potential defendant may prefer to learn in advance instead of risking punishment because a severe criminal sanction deters as much as an injunction); SCHAUER, supra note $189, \S 12.1$, at 228-29 (arguing for a preference for civil adjudication because heavy fines or prison terms chill a potential defendant's expression, lead to selfcensorship, more than an injunction); Mayton, supra note 61, at 253, 265, 275-76; Schauer, supra note 523, at 728; Scordato, supra note 158, at 8-9. 
A tort defendant concerned about the prospect of being potentially mulcted with certain litigation expenses and possible titanic compensatory damages for the plaintiff's lost reputation and emotional distress may also experience some goose bumps. ${ }^{620}$ A potential tort defendant's fear of being required to defend and pay damages may lead to self-censorship. ${ }^{621}$

Compensatory damages compensate; they do not punish. So a potential money judgment for compensatory damages draws the punishment side of subsequent punishment into doubt. ${ }^{622}$ However, the judge may have instructed the jury to consider punishment and deterrence in deciding whether to award and how to measure punitive damages, which can be considered to be the prior restraint doctrine's subsequent punishment.

The freeze side of the metaphor assumes that an injunction will be effective because the defendant will comply with it. This overstates the effect of an injunction because it assumes that an injunction is an absolute bar that halts speech. Many defendants do obey. ${ }^{623}$ If all defendants obeyed their injunctions, however, we would live in a better world. An injunction will not prevent all defendants' disobedience. The dolorous reality is that some defendants disobey injunctions and that plaintiffs and courts must respond with contempt. ${ }^{624}$

To say that an injunction shuts off communication assumes an injunction is like a stone wall that halts the defendant's progress or speech. A better metaphor is that an injunction resembles a stop sign. The driver or the defendant must put on the brakes, stop, or obey. ${ }^{625}$ The driver should stop. The defendant should obey.

An effective legal rule identifies and defines potential miscreants' misconduct without over- or under-deterring them. The rule should deter people from harmful activity without discouraging their wholesome activity.

620. See Harvard Law Review Ass'n, supra note 495, at 1009.

621. Gertz v. Robert Welch, Inc., 418 U.S. 323, 339, 350 (1974); Tarkington, supra note 455 , at 1582 .

622. Gertz, 418 U.S. at 385 (White, J., dissenting) (quoting Patterson v. Colorado ex rel. Attorney Gen., 205 U.S. 454, 462 (1907)).

623. See, e.g., Walker v. City of Birmingham, 388 U.S. 307, 336 (1967) (Douglas, J., dissenting) (citing Howat v. Kansas, 258 U.S. 181 (1992)).

624. Walker, 388 U.S. at 307. Similarly, if a criminal statute led to universal obedience, we would live in a more predictable, orderly, and peaceful world without criminal violations and prosecutions.

625. RendLEMAN, supra note 146, at 127. The original injunction metaphor was Professor Charles Wright's: "The injunction is not a set of handcuffs. In itself it cannot prevent the defendant from doing the criminal act." Charles Alan Wright, The Law of Remedies as a Social Institution, 18 U. DET. L.J. 376, 390 n.65 (1955); see also John M. Golden, Injunctions as More (Or Less) than "Off Switches": Patent-Infringement Injunctions " Scope, 90 TEX. L. REV. 1399, 1410-13, 1410 n.43, 1413 n.60 (2012). 
The legal system can express disapprobation and warn of consequences with a criminal statute, a civil damages rule, or an injunction.

The chilling effect argument against an injunction to forbid a defendant's defamation is that an injunction against one defendant's proved defamatory "speech may impermissibly chill [the defendant's or third persons'] otherwise lawful speech, to the detriment of First Amendment values." ${ }^{626}$ In short, an injunction against one defendant's unprotected defamation will overdeter others in the future by encouraging risk-aversive potential defendants to steer clear of potential trouble by eschewing protected expression. A specific no-injunction rule for defamation eliminates the possibility of discouraging the risk-aversive.

Scholars have criticized the chilling-effect doctrine beginning in 1978 with Schauer's examination of its loose, metaphorical assumptions. ${ }^{627}$ More recently, Professor Kinsley argued for it to be replaced with more detailed and functional analysis. ${ }^{628}$

The argument, or the fear, that an acceptable first decision may lead to an unacceptable second decision is called a slippery slope argument. ${ }^{629}$ In brief, the chilling effect metaphor is a slippery slope argument that the first decision will over deter. A no-injunction rule in defamation forces the judge to dispense with an injunction for a successful and meritorious defamation plaintiff because the judge must be concerned about a hypothetical future risk-aversive defamation defendant who, if sued, could prevail on the substantive issue of defamation.

"The Principle of the Dangerous Precedent," Cornford wrote from the decision maker's perspective, "is that you should not now do an admittedly right action for fear you, or your equally timid successors, should not have the courage to do right in some future case, which, ex hypothesi, is essentially different, but superficially resembles the present one." 630

The discussion of the chilling effect slippery slope argument started with the first decision maker's concern about a second decision maker. It moves to hypothetical future expression, the relation between the first decision

626. FISCHER, supra note $315, \S 28.0$, at 227 (stating, but not endorsing, the argument).

627. See Schauer, supra note 523, at 693.

628. See generally Jennifer M. Kinsley, Chill, 48 Loy. U. CHI. L.J. 253, 253-54

(2016) (advocating for replacement of chilling effect doctrine).

629. See generally WARD FARNSWORTH, THE LEGAL ANALYST: A TOOLKIT FOR THINKING ABOUT THE LAW 172-81 (2007) (discussing the consequences of one decision on another).

630. F.M. CORNFORD, Microcosmographia ACADEMICA BEING A GUIDE FOR THE Young ACADEMic Politian 31-32 (1923). 
maker and the risk-averse potential speaker who is concerned about what the second decision maker might do with or to him. ${ }^{631}$

Kinsley argues that the chilling-effect doctrine, based on unsupportable conjecture is unjustified in law. ${ }^{632}$ The judge's conjectures about the proposed injunction, phrased in terms of this Article, are: First, that the unknown second person would be aware of the first prohibition, the proposed injunction, if granted. ${ }^{633}$ Second, the person would understand how the proposed injunction would apply to second person's desired speech. ${ }^{634}$ Third, the second person would "conform" to the proposed injunction instead of risking similar treatment. ${ }^{635}$

The first judge may have reason to worry about the second person. The Alabama jury's large verdict in Sullivan threatened press reports of the Civil Rights movement. ${ }^{636}$ Defamation is factually contextual, and it has fuzzy substantive edges. Court decisions cannot be predicted with complete accuracy. "Even as society has internalized the values of free speech in abstract form, the particular applications of the principle of free speech remain counterintuitive to most people." ${ }^{637}$ This may lead a decision maker to err on the side of suppression. If a precise definition "requires for its application the understanding and internalizing of a corpus of principles beyond the comprehensive capacities of [risk-aversive lay potential speakers,] the interpreters, enforcers, and administrators, then each instance of lack of understanding increases the slippery slope risk." ${ }^{\text {"63 }}$

However, a line exists between unprotected and protected expression. Calling a home repair contractor a thief is palpably on the unprotected defamatory side of that line. In the first decision, the judge ought to emphasize whether the libel-victim plaintiff is entitled to an effective remedy. The judge should regard with cynical incertitude the present tortfeasor's crocodile tears of concern that an injunction against this defendant will discourage or deter a hypothetical risk-aversive potential speaker. As Schauer wrote, "slippery slope claims deserve to be viewed skeptically, and the proponent of such a claim must be expected to provide the necessary empirical support." 639

The chilling-effect argument posits the sequence that a decision against one speaker's unprotected expression will deter another later speaker's

631. See Kinsley, supra note 628, at 272-73.

632. Id. at 274.

633. Id.

634. Id.

635. Id. at 273-74.

636. GeOfFREy R. StONE, ET AL., THE FirSt AMENDMENT 141 (5th ed.) (2016).

637. Frederick Schauer, Slippery Slopes, 99 HARV. L. REV. 361, 377 (1985).

638. Id. at 375 .

639. Id. at 382 . 
protected speech. Although this deterrence has not been demonstrated by social science, scholars maintain that there is something to it. ${ }^{640}$ However, others' future conduct that is deterred does not occur; measuring deterrence is difficult because it purports to measure conduct that will not happen. ${ }^{641}$

Deterrence of a potential future speaker is complex and a subject of speculation. ${ }^{642}$ What deterrence effect has a criminal statute, a threat to prosecute someone for a potential crime? What about an actual criminal prosecution or a criminal conviction? Does a civil damages tort rule, a threat to sue someone for civil tort damages, or a civil tort damages money judgment differ? Would a threat to sue someone for an injunction or a lawsuit seeking an injunction, followed by an actual injunction deter? ${ }^{643}$ Will a judge's injunction freeze a person's speech more than a prosecutor's chilling threat to charge or indict someone for a crime?

Moreover, some threats will be hollow bluffs or unwarranted; some lawsuits, both criminal and civil, will fail. Finally, perhaps a court will hold that the criminal statute, the civil damages rule, or the injunction violates the First Amendment's free speech principles.

Human nature, events, the law, and the litigation process are too varied, complex, and volatile to be explained by a binary chill/freeze metaphor about an unknown future speaker's unknown expression. If a metaphor is needed, the more accurate one is the stop sign metaphor above.

An injunction, the tort law of defamation, and a criminal statute articulate the governing law and warn a potential speaker or injunction defendant what conduct or activity to avoid. The more functional approach is to compare an injunction to a tort standard or to a criminal statute not to a damages judgment or a criminal prosecution. ${ }^{644}$

A preventive or do not injunction will be less costly to the defendant than either a criminal conviction or a tort damages judgment. A potential libel defendant may even favor pre-publication adjudication because one may prefer to learn in advance before acting instead of speaking out and risking punishment. ${ }^{645}$ A declaratory judgment, as well as an injunction,

640. Anderson, Reforming, supra note 81, at 532-33.

641. LAWERENCE FreEdMan, StRATEGy: A History 159 (2013).

642. In their paired con and pro articles, Mayton and Hunter spar and speculate about expense and deterrence between a criminal statute and an injunction. Compare Mayton, supra note 61, at 245, with Hunter, supra note 156, at 283.

643. See Kinsley, supra note 628, at 274-75. Volokh is skeptical about claims of deterrence. See Volokh, supra note 2 (manuscript at 25, 34, 63).

644. OWEN M. FISS, INJUNCTIONS 51 (1972).

645. See PoSNER, supra note $619, \S 3.9$, at 70. 
is a pre-publication adjudication. ${ }^{646}$ The declaratory judgment will not frequently arise in our subject, internet defamation, where the publication has already occurred. Perhaps, Jeffries observed, if we assume, as we should, that the judge's decision to grant or deny a plaintiff an injunction is presumptively correct, then an injunction that adjudicates in advance whether someone's proposed expression will be defamatory may be a propitious idea. ${ }^{647}$ If a person must be a defendant, then one may prefer being an injunction defendant as a lesser threat than any of the other possibilities. If a judge decides that a potential defamation defendant's proposed publication is improper, then the potential defendant can withhold remarks, obey the injunction, and avoid the risk. Viewing the dispute from the defendants' side, after the judge grants the plaintiff a declaratory judgment or an injunction, the defendant goes home. But after the judge enjoins defendants and convicts them of criminal contempt, they may not.

When factual, legal, or contextual fuzziness emerges, the judge probably has remedial equitable discretion to delay a plaintiff's request for an interlocutory injunction until a fuller presentation and even to decline to grant a plaintiff a permanent injunction in favor of awarding him damages. ${ }^{648}$

A litigated, personalized, and targeted injunction based on specific facts articulates the law and applies it to the situation in context. An injunction "is the product of a concrete judicial proceeding prompted by particular events. ${ }^{\circ 649}$ It singles out the defendant as a party. It adjudicates by finding facts. An injunction forbids the defendant's misconduct by defining the proscribed speech or activity. It is drafted to fit the situation. ${ }^{650}$ It "does not embody the broad and abstract commands of a statute," or, for that matter, a tort standard. ${ }^{651}$

The prior restraint doctrine may discourage litigants from seeking injunctions that would accurately distinguish improper expression from legitimate expression. An injunction is analogous to a personal substantive tort standard or to a personal criminal statute. The defendant may heed the warning. Defendant's misconduct may never occur, or it may not be repeated. A correct injunction may end or prevent the defendant's unprotected defamatory expression. The injunction's advice may also facilitate the defendant's reconsideration, mid-course correction, and dissemination of protected

646. See Bray, supra note 382 , at 1095.

647. See Jeffries, supra note 162, at 412 n.14.

648. See generally Doug Rendleman, The Triumph of Equity Revisited: The Stages of Equitable Discretion, 15 NEV. L.J. 1397, 1404 (2015).

649. People ex rel. Gallo v. Acuna, 929 P.2d 596, 610 (Cal. 1997).

650. See Bray, supra note 382, at 1095.

651. Gallo, 929 P.2d at 610. 
expression better and more accurately than a generally phrased tort standard or criminal statute.

After the judge grants the plaintiff an injunction, the injunction is the equivalent of a personal criminal statute because the defendants' violation may subject them to contempt, perhaps criminal contempt. ${ }^{652}$ The point was made above that an injunction defendant's criminal contempt prosecution for a tort is not the most likely response. An injunction defendant may violate the injunction and defend against contempt, just as someone may violate a criminal statute and defend against prosecution. If the defendant breaches an injunction, the defendant's prosecution for, and perhaps conviction of, criminal contempt and punishment is parallel to the criminal prosecution that leads to the criminal sentence that is also punishment.

Like a defendant's criminal contempt, a defendant's criminal prosecution is retrospective; it looks to the past and follows the alleged misconduct. ${ }^{653}$ Injunction defendants are punished only if they are convicted of violation of the injunction and the judge imposes a criminal contempt sanction. ${ }^{654}$

The likelihood of an injunction defendant being charged with contempt and the type of contempt that will be charged are subject to speculation. Bickel wrote that a defendant who breaches an injunction "may be assured of being held in contempt." 655 Mayton agreed that contempt is "swift and certain." "656 A constitutional law treatise speculated that courts may tend to punish prior restraint violations more harshly because "[c]ourts are more adamant in punishing contempt of their orders than . . criminal statutes," in which they have no "personal stake." ${ }^{657}$ In short, however, we lack proof, even evidence, whether a criminal prosecution is more likely than a charge of contempt.

652. See Michael C. Macchiarola, "Hallowed By History, But Not By Reason": Judge Rakoff's Critique of the Securities and Exchange Commission's Consent Judgment Practice, 16 CUNY L. REV. 51, 75 (2012) (citing David M. Weiss, Reexamining the SEC's Use of Obey-the-Law Injunctions, 7 Bus. L.J. 6 (2006)).

653. See Universal Amusement Co. v. Vance, 587 F.2d 159, 174 (5th Cir. 1978) (quoting Kingsley Books, Inc. v. Brown, 354 U.S. 436, 442 (1957)), aff'd, 445 U.S. 308 (1980).

654. See, e.g., Vance, 445 U.S. at 322-23 (White, J., dissenting); FISS, supra note 644, at 725-26; see also Mayton, supra note 61, at 277 (discussing that punishment for violating an injunction follows a criminal contempt proceeding).

655. BICKEL, supra note 616, at 61 .

656. Mayton, supra note 61 , at 275.

657. JOHN E. NOWAK \& RONALD D. Rotunda, CONSTITUTIONAL LAW $\S 16.16(\mathrm{e})$, at 1305-06 (8th ed. 2010). 
How severe will contempt be if an injunction defendant is charged with contempt? If violations of intellectual-property injunctions are any indication, civil compensatory contempt seems more likely than criminal contempt. ${ }^{658}$ Compensatory contempt confesses that the injunction failed to secure the defendant's conduct, and it substitutes the inadequate remedy of compensation. ${ }^{659}$

The federal model requires the public authorities provide notice to prosecute criminal contempt. ${ }^{660}$ If a state follows that approach, a charge of criminal contempt for calling a home repair contractor a thief a second time seems to me to be less than certain. Contempt may be limited and light, Blasi wrote, without specifying the branch of contempt. ${ }^{661}$

Emerson compared censorship through the prior restraint of executive licensing with a criminal prosecution, not with an injunction. ${ }^{662}$ "[T] procedures do not require attention to the safeguards of the criminal process," he wrote. ${ }^{663}$ Redish's arguments against prior restraint favor the procedural protections in a criminal prosecution. ${ }^{664}$ We will consider in particular the protections of proof beyond a reasonable doubt and access to a jury.

A defamation defendant's criminal prosecution for libel is, as observed above, less likely than compensatory contempt. ${ }^{665}$ The defamation litigation this article examines is civil, in tort, for an injunction or money damages. The plaintiff's usual civil burden of proof is by a preponderance of the evidence. Proof beyond a reasonable doubt will not be required in the plaintiff's underlying suit for an injunction.

The defendant who allegedly violates an injunction may be charged with civil contempt or, less likely, with criminal contempt. The plaintiff may charge the defendant with civil contempt, compensatory contempt or coercive contempt, neither of which requires criminal procedural protections like proof beyond a reasonable doubt. ${ }^{666}$ The burden of proof in civil contempt is usually clear and convincing. ${ }^{667}$

658. See Golden, supra note 625, at 1410-13, 1410 n.43, 1413 n.60. Volokh's emphasizes criminal contempt. Volokh, supra note 2 (manuscript at 63).

659. See Rendleman, supra note 541, at 971. Volokh's Article mentions compensatory contempt which it calls a "financial sanction" and a "fine." Volokh, supra note 2 (manuscript at 14 n.48, 35-36).

660. Young v. U.S. ex rel. Vuitton et Fils S.A., 481 U.S. 787, 794-95 (1987); RENDLEMAN, supra note 146 , at $872-73$.

661. See Blasi, supra note 61, at 27.

662. See EMERSON, supra note 156, at 506.

663. Id.

664. See Redish, supra note 159, at 63-66, 99-100.

665. Golden, supra note 625, at 1410-13, 1410 n.43, 1413 n.60.

666. See RENDLEMAN, supra note 146, at 629, 659.

667. Id. at 726-27, 798-99, 860-61, 867. 
If it happens, an injunction defendant's trial and punishment for criminal contempt will not be summary. The procedural protections for a contemnor charged with criminal contempt will not differ much from the statutory crime defendant's because the criminal-contempt process will follow almost all of the procedural protections for a statutory criminal conviction, including an appointed lawyer for an indigent defendant. ${ }^{668}$ Proof beyond a reasonable doubt will be necessary to convict the defendant of criminal contempt. ${ }^{669}$ The criminal contempt contemnors will be entitled to a jury trial if they will be eligible for a sentence that exceeds six months' confinement. ${ }^{670}$

The government should not punish a defendant until after a judicial decision that the defendant's conduct was not protected by the First Amendment. That decision will occur after a trial for either criminal contempt, which seems unlikely, or, even less likely, for a statutory crime. In criminal contempt, the defendant's alleged misconduct, breach of the injunction, will have occurred. ${ }^{671}$

Arguments against an injunction as a prior restraint, even though later sanctions or damages are possible, turn out to be founded on an illusory distinction. ${ }^{672}$ A charge of criminal contempt that follows an injunction and the defendant's dissemination of expression is not "prior" at all because the defendant's punishment for criminal contempt will occur after the alleged breach. ${ }^{673}$

The collateral bar rule, where applicable, may prevent criminal contempt contemnors from arguing that their expression deserves First Amendment protection. That is a major reason for a court to reject the collateral bar rule in criminal contempt for a defendant's alleged breach of an injunction that forbids defamation. ${ }^{674}$

668. See id. at 629; Volokh, supra note 2 (manuscript at 30-31).

669. RENDLEMAN, supra note 146, at 659.

670. Bloom v. Illinois, 391 U.S. 194, 211 (1968). If the contemnor's misconduct would also be a statutory crime, the contemnor will be entitled to a jury in federal court, a situation not anticipated here. 18 U.S.C. $\S \S 3691-92$ (2012).

671. RendLEMAN, supra note 146, at 629 . Volokh emphasizes a jury and proof beyond a reasonable doubt in criminal contempt. See Volokh, supra note 2 (manuscript at 27-28, $35)$.

672. See Ardia, supra note 1, at 34-38.

673. Id. at 36. Volokh makes the important point that criminal prosecutions and criminal contempt follow speech and are not prior. See Volokh, supra note 2 (manuscript at 16).

674. See id. at 36-37, 37 n.161. 


\section{CONCLUSION}

Anyone who has read this far will not be surprised that, under limited circumstances, I favor an injunction to forbid a defendant's proved defamation.

At first blush, the reader may conclude that I am sailing my small craft into a small craft warning. In 1962, Kauper wrote that, "[i]t is, nevertheless, true that the Court has repeatedly said that freedom from prior restraint is the most important feature of freedom of the press, and certainly history supports this conclusion." ${ }^{\text {675 }}$ A little later Professor Magnetti reminded us that:

[G]iven the United States Supreme Court's consistent zealous protection of first amendment rights in recent decisions, it is difficult to imagine that the prior restraint doctrine will give way to the availability of injunctive relief as a feasible remedy to a plaintiff harmed by a continuous calculated campaign to destroy his reputation. ${ }^{676}$

In 1994 in CBS, Inc. v. Davis, the Supreme Court wrote: "Subsequent civil or criminal proceedings, rather than prior restraints, ordinarily are the appropriate sanction for calculated defamation or other misdeeds in the First Amendment context." ${ }^{\text {"77 }}$ In 2012, rejecting one of this Article's featured decisions, Balboa, Judge Pregerson wrote that:

It, of course, is difficult to defend any absolute position, even this one that injunctions never should be permitted in defamation cases. But it seems less extreme if it is remembered that never in the 216 year history of the First Amendment has the Supreme Court found it necessary to uphold a prior restraint in a defamation case or any other. 678

Finally, Judge Sack wrote that injunctions against speech and press are "virtually extinct." 679

Scholars in earlier generations, including iconic Roscoe Pound, have expressed sentiments similar to mine that favor limited injunctions, in

675. KAUPER, supra note 45 , at 85.

676. Magnetti, supra note 405 , at 332.

677. CBS, Inc. v. Davis, 510 U.S. 1315, 1318 (1994).

678. Oakley, Inc. v. McWilliams, 879 F. Supp. 2d 1087, 1092 (C.D. Cal. 2012).

679. Sack, supra note 85 , at 278. 
different ways and using different vocabularies. ${ }^{680}$ Courts in other nations grant injunctions against defendants' defamation. ${ }^{681}$

Although they are not congruent with every point I have made above, strong recent scholarship by Ardia, Volokh, and Dean Chemerinsky supports a limited defamation injunction. ${ }^{62}$ And the Kentucky court, while rejecting a preliminary injunction against defamatory speech, followed Balboa in approving a tailored final injunction after a plenary decision. ${ }^{63}$ The Delaware Chancery court, citing state Supreme Courts, federal Courts of Appeals and lower courts, noted a trend: an injunction is possible against defamation found in an adversary hearing. ${ }^{684}$

As Pomeroy wrote in 1887, "a remedy which prevents a threatened wrong is, in its essential nature, better than a remedy which permits a wrong to be done, and then attempts to pay for it." ${ }^{\prime 65}$ A steady functional analysis points toward a changing or changed frame of reference. To those sources, this article adds careful analysis of defamation damages and remedies, injunctions, contempt, and equitable issues.

An injunction has many advantages. It identifies and singles out the defendant and the misconduct. It follows adversary judicial procedure. Drafting a satisfactory injunction is daunting. An injunction that is too narrow may have limited effect. An injunction that is too broad may be too vague

680. See, e.g., Bertelsman, supra note 157, at 337; Gold, supra note 300 , at 259 \& n.129; Harvard Law Review Ass'n, supra note 495, at 1011-12; Harvard Law Review Ass'n, Developments in the Law-Defamation, 69 HARV. L. REV. 875, 944 \& n.489 (1956); Jeffries, supra note 162, at 409; Mayton, supra note 61, at 281; Roscoe Pound, Equitable Relief Against Defamation and Injuries to Personality, 29 HARV. L. REV. 640, 665 (1916); Robert Allen Sedler, Injunctive Relief and Personal Integrity, 9 ST. LouIs U. L.J. 147, 150 (1964). A "[s]pecial note on remedies for defamation other than damages" suggests that injunctive relief "might meet the need" of certain defamation cases after the court has "formally determined" defamation. RESTATEMENT (SECOND) OF TORTS, at xv, § $623 \mathrm{cmt}$. B(3) (AM. LAW INST. 1976). After hesitation, I decided to cite my own Complex Litigation casebook and its prior editions. See generally FISS, supra note 644, at 127-55; OWEN M. FISS \& DOUg RENDLEMAN, INJUNCTIONS ch. 4 (2nd ed. 1984); RENDLEMAN, supra note 146, at ch. 13.

681. See Jefrerey Berryman, The Law of Equitable Remedies 83 (2d ed. 2013). See generally Hilary Young, The Scope of Canadian Defamation Injunctions (2019) (unpublished manuscript) (on file with author).

682. Ardia, supra note 1, at 83-84; Chemerinsky, supra note 497, at 1460-61; Volokh, supra note 2 .

683. See Hill v. Petrotech Res., Corp., 325 S.W.3d 302, 313 (Ky. 2010).

684. Organovo Holdings, Inc. v. Dimitrov, 162 A.3d 102, 123-24 (Del. Ch. 2017).

685. 3 JOHN NORTON POMEROY, POMEROY's EQUITY JURISPRUDENCE AND EQUITABLE REMEDIES: A TREATISE ON EQUITY JURISPRUDENCE § 1357 (1887). 
or forbid protected activity. An injunction should be drafted to fit the situation. It is preventive, not retrospective. It says "go, and sin no more." It is neither damages nor punishment. A potential speaker may prefer adjudication in advance.

In short, if my proposals are adopted, the judge may augment usual civil injunction procedure before granting a plaintiff an anti-defamation injunction. An anti-defamation injunction will be preceded by notice to the defendant and an opportunity for the defendant to be heard in defense. An interlocutory injunction should follow an adversary hearing before the judge, and crossexamination is preferred. A careful judge will consider nuance and context, exercise equitable discretion, and, with the defendant's participation, draft a personalized specific injunction that fits the law to the events, the discrete defamation. Neither proof beyond a reasonable doubt nor a jury trial should be required before the judge enjoins the defendant's specific defamation.

This Article favors an injunction drafted to forbid the defendant's speech that the judge has adjudicated to be defamation. The process and the personally addressed injunction will bring the potential consequences of violation home to the defendant. The dispute will be resolved in court rather than in the blogosphere. A defendant charged with criminal contempt will be entitled to criminal procedural protections before being convicted.

Courts ought to repeal the Maxim that Equity will not enjoin defamation. ${ }^{687}$ In a public-figure's damages lawsuit, defamation is speech that is entitled to the deference of the Sullivan privileges. ${ }^{688}$ A defendant's proved defamation tort is not entitled to First Amendment protection that extends to prevent the judge from granting the plaintiff an injunction that forbids that defamation.

The prior restraint doctrine tells a court to prefer retrospective civil tort damages to a preventive injunction. A judge should compare forbidding the defendant's tort in advance with awarding the plaintiff damages after the tort. The judge should be wary of standing aside while the defendant's defamation tort occurs, only to substitute money later for the plaintiff's business losses, impaired reputation, and emotional distress.

The Supreme Court in Near added an injunction to executive licensing as a prior restraint and a disfavored remedy for a defendant's expression. ${ }^{689}$ The Court treated an injunction as even more disfavored than a criminal prosecution or a civil damages action. ${ }^{690}$ Times have changed. An injunction that stems from ex parte or inadequate procedure is an improper procedural

\footnotetext{
686. John 8:11 (King James).

687. Kinney v. Barnes, 443 S.W.3d 87, 95 (Tex. 2014) (quoting Kramer v. Thompson, 947 F.2d 666, 677 (3d Cir. 1991)).

688. See N.Y. Times Co. v. Sullivan, 376 U.S. 254, 283 (1964).

689. See Near v. Minnesota ex rel. Olson, 283 U.S. 697, 721 (1931).

690. Id. at 711 .
} 
prior restraint. Opinions are not defamatory. An injunction against a defendant's professional opinion would be an improper prior restraint. ${ }^{691}$ An injunction that forbids non-defamatory expression is improper because it is too broad. The judge has equitable discretion in deciding between damages and an injunction and, additionally, in drafting the injunction. An injunction can be an improper prior restraint if it stemmed from inadequate procedure or if it is badly drafted, too broad or too vague. The law of injunctions and the law of defamation have matured and developed enough that courts should liberate an adjudicated injunction that forbids defendant's specific defamation from the anomaly of being treated as a prior restraint like executive censorship.

Granting, drafting, and administering an injunction that forbids the defendant from repeating specific defamation or that requires the defendant to remove identified defamation does not present insurmountable First Amendment problems. Under the circumstances examined and explained above, a judge should consider that an injunction is not a prior restraint but an appropriate remedy for a defendant's proved defamation. Sometimes the answer is not more speech.

Baldder v. Lokki involves intentional, perhaps malicious, libel. If plaintiff proves defendant's intentional, malicious libel in an evidentiary hearing, the judge should grant an injunction that requires the defendant to remove the defamation and to not repeat it. One possible impediment stems from Baldder's risk that Lokki's private incorrect libel could be re-characterized as Baldder's limited public-figure plaintiff's claim under the heading of the public issue of consumer protection to qualify the defendant for Sullivan privileges; Lokki's intentional misstatement, may, however, surmount the Sullivan Court's "actual malice" test. ${ }^{692}$

691. See Saad v. Am. Diabetes Ass'n, No. 15-10267-TSH, 2015 WL 751295, at *1-2 (D. Mass 2015 Feb. 23, 2015).

692. See N.Y. Times Co., 376 U.S. at 280. 
